University of Michigan Law School

University of Michigan Law School Scholarship Repository

Articles

Faculty Scholarship

1999

\title{
Markets as Monitors: A Proposal to Replace Class Actions with Exchanges as Securities Fraud Enforcers
}

\author{
Adam C. Pritchard \\ University of Michigan Law School, acplaw@umich.edu
}

Available at: https://repository.law.umich.edu/articles/513

Follow this and additional works at: https://repository.law.umich.edu/articles

Part of the Legal Remedies Commons, Legislation Commons, Litigation Commons, and the Securities Law Commons

\section{Recommended Citation}

Pritchard, Adam C. "Markets as Monitors: A Proposal to Replace Class Actions with Exchanges as Securities Fraud Enforcers." Va. L. Rev. 85, no. 6 (1999): 925-1020.

This Article is brought to you for free and open access by the Faculty Scholarship at University of Michigan Law School Scholarship Repository. It has been accepted for inclusion in Articles by an authorized administrator of University of Michigan Law School Scholarship Repository. For more information, please contact mlaw.repository@umich.edu. 


\title{
VIRGINIA LAW REVIEW
}

\begin{tabular}{lll}
\hline VOLUME 85 & SEPTEMBER 1999 & NUMBER 6 \\
\hline
\end{tabular}

\section{ARTICLES}

\section{MARKETS AS MONITORS: A PROPOSAL TO REPLACE CLASS ACTIONS WITH EXCHANGES AS SECURITIES FRAUD ENFORCERS}

\author{
A.C. Pritchard ${ }^{*}$
}

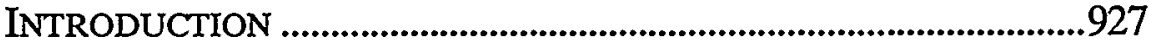

I. CAUSES AND COSTS OF FRAUD ON THE MARKET .........................930

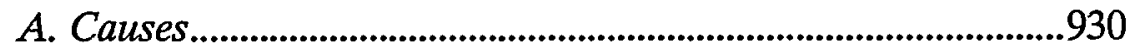

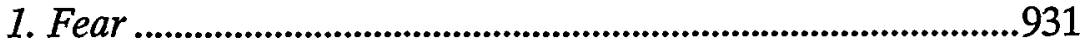

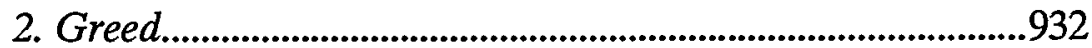

3. Pollyannaism .......................................................................9934

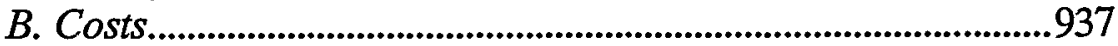

1. Reduced Managerial Accountability..................................937

2. Liquidity Costs ........................................................................938

* Assistant Professor, University of Michigan Law School. M.P.P., University of Chicago; J.D., University of Virginia School of Law; Council of Scholars, Foundation for Economic Education. Much of the research and writing of this Article was done while I was a Visiting Assistant Professor at the Northwestern University School of Law. I would like to thank Jennifer Arlen, Stuart Banner, John Beckerman, Bob Cooter, Jill Fisch, Merritt Fox, Jesse Fried, Lanae Holbrook, Vic Khanna, Don Langevoort, Joan Larsen, Kyle Logue, Ronald Mann, Bob Rasmussen, Mark West, Michelle White, and participants at the 21st Century Change Imperative: Evolving Organizations \& Energing Networks Conference sponsored by the University of Missouri-Columbia and the University of Michigan Law School Law and Economics Workshop, as well as participants at presentations at the Boston University, University of Califorma-Berkeley, University of Chicago, Chicago-Kent, George Mason University, Harvard University, University of Michigan, Northwestern University, Ohio State University, University of Pennsylvania, University of Texas, Umversity of Califormia-Los Angeles, Vanderbilt University, and Washington University law schools for helpful comments on earher versions of this Article. Financial support for this project was provided by the Cook Fund of the University of Michigan. 
3. Capital Allocation …................................................................995

II. COMPENSATION OR DETERRENCE? ……...................................995

A. Class Actions and the Conflict Between

Compensation and Deterrence.................................................947

1. Incentives of Plaintiffs' Lawyers .........................................948

2. Defendants' Incentives .......................................................952

B. The Private Securities Litigation Reform Act.........................959

III. EXCHANGE INCENTIVES ......................................................963

A. Structure ..................................................................................965

B. Broker-Dealer Incentives.......................................................966

C. SEC Oversight ........................................................................976

D. Why Don't Exchanges Enforce

Antifraud Sanctions Now? ........................................................981

E. Summary of Exchange Monitoring Advantages ....................982

IV. THE EXCHANGE ALTERNATIVE .................................................983

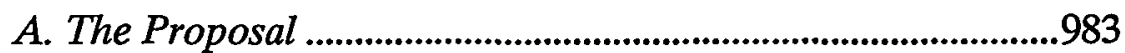

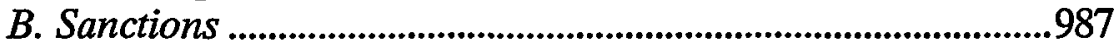

1. Monetary Sanctions ......................................................................987

2. Injunctive Relief ......................................................................991

3. Shareholder Approval for Delisting.......................................992

4. Vicarious Liability ....................................................................992

5. Secondary Liability ...............................................................995

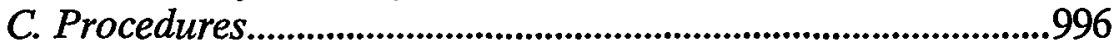

V. HISTORY ................................................................................1000

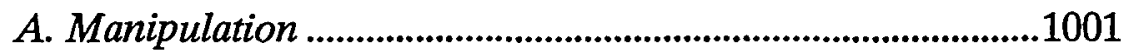

B. Fixed Commissions ................................................................1011

C. Nonvoting Common Stock ........................................................1013

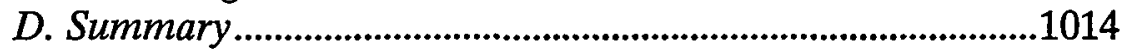

VI. ALTERNATIVES TO EXCHANGE ENFORCEMENT ....................1015

A. Reforming Class Actions ........................................................1015

1. Limiting Damages ..................................................................1015

2. Auctioning Class Actions.......................................................1016

B. SEC Enforcement ..................................................................1017

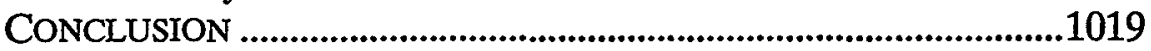




\section{INTRODUCTION}

FRUD in the securities markets has been a focus of legislative reform in recent years. Corporations - especially those in the high-technology industry-have complained that they are being unfairly targeted by plaintiffs' lawyers im class action securities fraud lawsuits. ${ }^{1}$ The corporations' complaints led to the Private Securities Litigation Reform Act of 1995 ("Reform Act"). ${ }^{2}$ The Reform Act attempted to reduce meritless hitigation against corporate issuers by erecting a series of procedural barriers to the filing of securities class actions. Plaintiffs' attorneys warned that the Reform Act and the resulting decrease in securities class actions would leave corporate fraud unchecked and deprive defrauded investors of compensation, thereby undermining investor confidence in the inarkets. ${ }^{3}$ Despite these dire predictions, however, after a brief initial declime securities fraud class actions are now being filed in greater numbers than before the passage of the Reform Act. ${ }^{4}$ Reform efforts thus continue. The President recently signed legislation preempting state securities class actions, which were thought to be avenues for circumventing the Reform Act's restrictions. ${ }^{5}$

The principal target of reform has been class action lawsuits against corporations. Such lawsuits are based on misstatenients by corporate officers that distort the secondary niarket price of the corporation's securities. ${ }^{6}$ In these so-called "fraud on the market"

${ }^{1}$ See Richard H. Walker et al., The New Securities Class Action: Federal Obstacles, State Detours, 39 Ariz. L. Rev. 641, 641-46 (1997) (describing criticisms offered of securities class actions by those seeking reform).

2 Pub. L. No. 104-67, 109 Stat. 737 (codified as amended in scattered sections of 15 U.S.C. $\$ \$ 77-78$ (Supp. III 1997)) [hereinafter Reform Act].

${ }^{3}$ See Hearings on Sec. Litig. Reform Proposals Before the Subcomm. on Sec. of the Senate Comm. on Banking, Housing, and Urban Affairs, 104th Cong. 193 (1995) [heremafter Hearings on Sec. Litig. Reform] (statement of David J. Guin, testifying on behalf of the National Association of Securities and Commercial Law Attomeys) (arguing that strengthened securities laws are necessary to maintain investor confidence).

4 See David M. Levine \& Adam C. Pritchard, The Securities Litigation Uniform Standards Act of 1998: The Sun Sets on Califorma's Blue Sky Laws, 54 Bus. Law. 1, 41-42 (1998).

${ }^{5}$ See Securities Litigation Uniform Standards Act of 1998, Pub. L. No. 105-353, 112 Stat. 3227 (1998) [heremafter Uniform Standards Act]. The Uniform Standards Act is discussed in Levine \& Pritchard, supra note 4.

' See John W. Avery, Securities Litigation Reform: The Genesis of the Private Securities Litigation Reform Act of 1995, 51 Bus. Law. 335, 338-39 (1996) (describing 
cases, plaintiffs' attorneys sue the corporation and its officers under Rule 10b-5 of the Securities Exchange Act. ${ }^{7}$ They sue on behalf of classes of investors who have paid too much for their shares or (less frequently) sold their shares for too little because of price distortion caused by the misstatements. In the typical case, the corporation has neither bought nor sold its securities, and, accordingly, has not benefited from the fraud. Investors can nonetheless recover their losses from the corporation based on its managers' misstatements. Given the volume of trading in secondary trading markets, the damages recoverable in such suits can be a substantial percentage of the corporation's total capitalization, reaching the tens or even hundreds of millions of dollars. Advocates of reform contend that risk-averse managers are too anxious to settle such suits, even when the suits have little merit. Settlement is attractive because it allows managers to avoid personal liability by paying the claims with the corporation's money.

My argument is that we should stop attempting to reform fraud on the market class actions and instead replace them with organizations better suited to the task of antifraud monitoring. In this Article I analyze the social costs created by fraud on the market and the roles of compensation and deterrence in reducing the costs of fraud. I argue that compensation does not play an important role in controlling those costs. Accordingly, a rational imvestor would not willingly pay for the coinpensation provided by the class action regime if deterrence could be achieved at a lower cost through alternative ineans.

The lower-cost alternative that I propose is antifraud enforcement by the securities exchanges where the trading affected by the fraud took place. ${ }^{8}$ The primary social cost of fraud on the market is

typical securities fraud class action). In this Article, I do not address fraud in the initial distribution of securities where investors are in privity (or near privity) with the corporation. Fraud in the primary market for securities raises a series of issues not found in secondary inarket fraud, the most important one being the need to coinpensate defrauded investors. See infra note 249 and accompanying text.

${ }^{7}$ See 15 U.S.C. $\$ \$ 78 \mathrm{a}-78 \mathrm{~mm}$ (1994); 17 C.F.R. \$ 240.10b-5 (1998) (making unlawful "Inanipulative and deceptive devices and contrivances").

${ }^{8}$ I use "exchanges" here in its colloquial sense to refer to any organized market where corporations can list their securities for trading and where broker-dealers are inembers of the exchange and are subject to its regulation. This definition would include not only the New York and American Stock Exchanges ("NYSE" and "AMEX," respectively) but also the National Association of Securities Dealers 
less trading by investors who seek to avoid being on the losing end of a trade that occurs at a fraudulently distorted market price. The reduction in hquidity caused by lower trading volume most directly harms broker-dealers, who depend on trading and trading commissions for a substantial portion of their revenues. Broker-dealers hold a property right in their exchange memberships, which effectively makes them the residual claimants of the exchanges. Thus, the incentives of the exchanges' members should push exchanges to enforce vigorously prohibitions agaimst fraud on the inarket. ${ }^{9}$

Part I analyzes the causes of fraud in secondary trading markets and the social costs produced by fraud. Part II discusses the roles of compensation and deterrence in controlling those costs and concludes that deterrence, not compensation, should be the primary objective of an antifraud regime. Part II then looks at the compen-

Automated Quotations/National Market System ("NASDAQ/NMS"), administered by the National Association of Securities Dealers ("NASD"), which is, strictly speaking, not an exchange. The NASDAQ/NMS system is the functional equivalent of an exchange. The definition used here would exclude, however, other segments of the over-the-counter market such as the Bulletin Board and the "pink sheets." See Jonathan Macey \& Hideki Kanda, The Stock Exchange as a Firm: The Einergence of Close Substitutes for the New York and Tokyo Stock Exchanges, 75 Cornell L. Rev. 1007, 1050 (1990) ("[T]he computer linkages provided by NASDAQ have transformed the U.S. over-the-counter market into an electronically linked exchange."). The AMEX and the NASD recently merged their operations into a single entity. The discussion in this Article focuses on the NYSE's incentives, but the analysis of the NASDAQ/NMS is essentially the same.

${ }^{9}$ As this Article was going to print, it was announced that both the NYSE and NASD were contemplating conversion from nonprofit to for-profit status, to be followed up by initial public offerings. See Greg Ip, Trading Places: The Stock Exchanges, Long Static Suddenly Are Roiled by Change, Wall St. J., July 27, 1999, at A1. The demutualization proposals would allow the organizations greater flexibility in responding to the competitive threat posed by electronic trading systems. The exchanges would become inore fiexible because they would be less constrained by i $m$ terest group conflicts within the membership, e.g., differences between investinent bankers and trading specialists. See Greg Ip, Big Board May Go Public by November, But Tax Issue Could Becoine An Obstacle, Wall St. J., July 26, 1999, at C1. It is unclear that this possibility would interfere with the proposal outlined here-a change to for-profit status would do nothing to reduce the exchanges' incentives to compete for listings or trading volume. Insofar as the need to dehver profits to shareholders might make exchange officials inore conscious of regulatory costs, that would enhance the efficiency of the antifraud regime, as officials would have to inake sure that their enforceinent actions were cost-justified. The marginal effect on imvestor confidence in that exchange would be the benefit; enforceinent expenses and potentially discouraging listings would be the cost. By and large, for-proflt status enhances existing incentives of exchanges to inaximize trading volume and listings; it does not change their fundamental business. 
satory class action regime and shows how the goal of compensation undermines the deterrent value of class actions. Part III assesses the organization and regulation of the exchanges and how they affect the exchanges' potential role as enforcement monitors. Part IV outlines an alternative enforcement regime administered by the securities exchanges where the trading affected by fraud took place. Instead of paying money damages to investors, corporations-along with their managers and outside professionals-would pay civil penalties and disgorge fraudulently obtained benefits to the exchanges. Corporations and their affiliates would also be subject to injunctive relief. Part V discusses potential criticisms of niy proposal based on the NYSE's historical enforceinent record and the implications of that history for exchange antifraud enforcement. Part VI evaluates potential alternatives to my proposal. Finally, a brief Conclusion summarizes the main advantages of exchange antifraud enforceinent.

\section{CAUSES AND COSTS OF FRAUD ON THE MARKET}

\section{A. Causes}

At first glance, it is a puzzle why corporations would ever con1mit fraud on the market, as they receive no pecuniary benefit from the fraud. Moreover, these misstatements are unlikely to remain concealed indefimitely, and the corporation will pay a price in the capital markets once the fraud is revealed. ${ }^{10}$ The puzzle, however, is easily solved. Corporations are legal fictions-they do not make misstatements that affect stock prices on their own; rather, their agents, the officers of the corporation, make the misstatements that give rise to liability for the corporation. The available evidence suggests that fraud on the market usually reflects the hunian frail-

${ }^{10}$ See Jennifer H. Arlen \& William J. Carney, Vicarious Liability for Fraud on Securities Markets: Theory and Evidence, 1992 U. Ill. L. Rev. 691, 701 ("Corporations relying on public markets for sources of future financing expect to be repeat players in securities markets; consequently, they would find the long-term cost of Fraud on the Market far higher than any short-term payoffs."); see also Christine A. Botosan, Disclosure Level and the Cost of Equity Capital, 72 Acct. Rev. 323 (1997) (finding the same relationship to the cost of equity capital; Partha Sengupta, Corporate Disclosure Quality and the Cost of Debt, 73 Acct. Rev. 459, 472-73 (1998) (finding that corporations receiving higher disclosure ratings from financial analysts have a lower cost for debt issues). 
ties of those agents: fear, greed, and pollyannaism." Less cominonly, managers may lie in an attempt to protect shareholders or the corporate enterprise.

\section{Fear}

Jennifer Arlen and William Carney argue that fraud on the narket often reflects a "last period" problem for corporate managers." In their study of 111 reported fraud on the market decisions froin 1975 to 1990 , Arlen and Carney found that nearly $70 \%$ of the cases involved attempts to conceal earnings declines or other bad news about the issuer, and that another $20 \%$ involved allegations of falsely optimistic statements about the issuer's prospects. ${ }^{13}$ They surmise that corporate managers, fearing the loss of their jobs if perforinance continues to suffer, make such misstatements in order to buy time to turn the prospects of the company around. ${ }^{14}$ These efforts have a high rate of failure: Nearly $25 \%$ of the firnis later found themselves in bankruptcy. ${ }^{15}$ Unsurprisingly, corporate inanagers have a high rate of turnover in bankruptcy. ${ }^{16}$ Arlen and Carney conclude that

Fraud on the Market is a risky short-terni strategy engaged in by senior inanagers, without the approval of either the board of directors or a inajority of the shareholders. Almost all of these frauds were designed to deceive the inarket and current shareholders into believing that the firm's financial situation was better than it was. ${ }^{17}$

"See infra Sections I.A.1-3.

12 Arlen \& Carney, supra note 10, at 691, 693, 703.

${ }^{13}$ See id. at 721-34.

${ }^{14}$ See id. at 726 ("[F]raud is likely to appear to be a viable option only for a manager of a failing company who thinks that he can turn the company around and perhaps obtain new financing in the intervening period.").

is See id. at 726.

${ }^{16}$ See Stuart C. Gilson, Bankruptcy, Boards, Banks and Blockholders: Evidence on Changes in Corporate Ownership and Control when Firms Default, 27 J. Fin. Econ. 355,356 (1990) (finding that, on average, $43 \%$ of the CEOs are still present when their firms emerge from bankruptcy or settle privately with creditors less than two years later); Lynn M. LoPucki \& William C. Whitford, Patterns in the Bankruptcy Reorganization of Large, Publicly Held Companies, 78 Cornell L. Rev. 597, 610 (1993) (finding that there was $70 \%$ CEO turnvover during, or in anticipation of, bankruptcy proceedings).

17 Arlen \& Carney, supra note 10 , at 730. 
Their findings suggest that corporate agents, not corporations, benefit from fraud on the market, and that the agents commit fraud out of fear of losing their positions. ${ }^{18}$ Surveys of auditors support the proposition that fear is an important motivation for fraud. Auditors report that inadequate profitability relative to the industry and managers who place undue emphasis on meeting earnings projections are the two leading "red flags" for fraud in financial statements. ${ }^{19}$ Although improving profitability and meeting earnings projections benefit shareholders, falsely signaling that these goals have been achieved does not. Shareholders are victims, not beneficiaries, of their agents' misstatements motivated by entrenchment.

\section{Greed}

The conclusion that shareholders do not benefit from fraud is bolstered by the explanations typically offered for fraud on the market in class action complamts. Nearly $50 \%$ of class action complaints allege that the fraud was motivated by opportunities for insider trading. ${ }^{21}$ These complaints typically allege that corporate insiders make misstatements so that they can unload their holdings

${ }^{18}$ Additional support is found in Francois Degeorge et al., Earnings Management to Exceed Thresholds, 72 J. Bus. 1 (1999). They find that managers manipulate earnings to meet certain thresholds: (1) to show profits, rather than losses; (2) to show higher earnings than the prior year; and (3) to meet analysts' projections. See id. at 30 . Failure to meet these thresholds sends a highly visible signal to the board of directors that managers are not meeting expectations. See Cindy R. Alexander \& Mark A. Cohen, Why Do Corporations Become Criminals? Ownership, Hidden Actions and Crime as an Agency Cost, 5 J. Corp. Fin. 1 (1999) (finding that corporate inanagers commit crimes to benefit themselves rather than the corporation).

${ }^{19}$ James K. Loebbecke et al., Auditors' Experience with Material Irregularities: Frequency, Nature, and Detectability, 9 Auditing: J. Pract. \& Theory 1, 16-17 tbl.9 (1989).

${ }^{20}$ The one exception would be shareholders who are fortunate enough to sell out before the price collapses. While the inanagers' fiduciary duties run to current, rather than prospective, shareholders under Delaware law, federal antifraud law dictates that duties rum to both. See A.C. Pritchard, United States v. O'Hagan: Agency Law and Justice Powell's Legacy of the Law of Insider Trading, 78 B.U. L. Rev. 13, 26-27 (1998) (discussing the treatment of this issue in Chiarella v. United States, 445 U.S. 222 (1980)).

${ }^{21}$ See Walker et al., supra note 1, at 651 (reporting that $48 \%$ of securities class actions filed in 1996 contained allegations of insider trading). 
at inflated prices. ${ }^{22}$ The resulting wealth transfers from outside investors to corporate insiders reduce the profitability of investing in securities. Rational investors will discount accordingly the price that they are willing to pay for securities. This discounting will be reflected in the corporation's cost of capital-rational purchasers in public offerings, knowing that the resale price of their securities will be discounted in the secondary trading markets to reflect insider trading costs, will themselves discount the price they are willing to pay for shares in the original offering by the company.

Other typical allegations in class action complaints include attempts to manipulate option or other compensation plans tied to the coinpany's stock price. ${ }^{23}$ Where corporate managers have made misstatements that depressed their coinpany's stock price, complaints commonly allege that the inanagers were trying to buy the

2 To be sure, these allegations should be taken with a grain of salt-many are found in lawsuits against companies in the high-technology industry, in which stock options make up a large portion of executives' compensation. See Jordan Eth \& Michael Dicke, Insider Stock Sales in Rule 10b-5 Corporate Disclosure Cases: Separating the Innocent from the Suspicious, 1 Stan. J.L. Bus. \& Fin. 97, 100-01 \& n.18 (1994). It is not surprising that these corporate officers would be selling during the period of alleged fraud because they sell in virtually all periods. See id. at 109 ("there nearly always are some insiders selling stock im a given time period"); Richard M. Phillips \& Gilbert C. Miller, The Private Securities Litigation Reform Act of 1995: Rebalancing Litigation Risks and Rewards for Class Action Plaintiffs, Defendants and Lawyers, 51 Bus. Law. 1009, 1013 (1996) ("[I]nsider selling is common [for Silicon Valley firms] because executives of entrepreneurial firms are often paid with stock options instead of cash."). But some exaniples demonstrate such massive sales, out of proportion to all prior selling, that it is difficult to escape the inference that corporate insiders were using fraud as a means of unloading their holdings on unsuspecting imvestors. See, e.g., Emily Nelson, Ex-Cendant Chairman Walter Forbes Sold $\$ 30$ Million of Stock During Scam, Wall St. J., Sept. 28, 1998, at B5. Allegations of insider trading in class action complaints doubled in response to the Reform Act's heightened standard for pleading scienter. See Vanessa O'Connell, Lawyers Scan Insider Sales To Build Suits, Wall St. J., June 5, 1996, at C1. The effect of the Reform Act's pleading requirements is discussed infra notes 140-44 and accompanying text.

${ }^{23}$ As an article authored by three plaintiffs' attorneys puts it,

[E]xecutives whose compensation is tied to the stock price of their companies' shares, or who have options to exercise or shares to sell, have a subtle but powerful motive to close their eyes to bad news percolating upward from the ranks, and postpone giving it serious consideration, let alone disclosing it publicly, until the next quarter or two.

David J. Bershad et al., A Dissenting Introduction, in Securities Class Actions: Abuses and Remedies 5, 19 (Edward J. Yodowitz et al. eds., 1994). 
shareholders out at a bargain price. ${ }^{24}$ These allegations revolve around a common theme: self-dealing in breach of the manager's duty of loyalty to the corporation and its shareholders. Managerial greed, at shareholders' expense, motivates these misstatements.

\section{Pollyannaism}

Donald Langevoort argues that fraud on the market may come froin a less venal source. ${ }^{25}$ He suggests that the biases of corporate culture affect the decisionmaking of corporate executives. ${ }^{26}$ In particular, Langevoort focuses on the optimism that seems to be embedded in many corporate cultures, and consequently, in many corporate statements. ${ }^{27}$ He sees this optimism, not as a form of self-dealing by corporate managers, but rather, as an artifact of organizational information flows. ${ }^{20}$ In his model, mid-level managers have the greatest access to information in the firm, but they may have an imcentive to distort that information as they pass it up to their superiors:

[T]he natural reporting teinptation is to transmit information in a way that minimizes the potential for blaming oneself for bad news, and to convey as much good news as possible to the extent that the information can be attributed to the sourceconsistent, of course, with a general desire to have a reputation for credibility with one's superiors. ${ }^{29}$

${ }^{24}$ See Arlen \& Carney, supra note 10, at 725 ("[O]f the cases in which managers understated the value of the securities, closer examination of these cases reveals that typically they involve managers and control shareholders who were alleged to have a conflict of interest because they were attempting to buy out the public shareholders at an unfairly low price."). Indeed, such a case inspired the Securities and Exclrange Commission ("SEC") to proinulgate Rule 10b-5, the basis for fraud on the market lawsuits. See Milton Freeman, Foreword to Colloquium, 61 Fordham L. Rev. S1 (1993).

${ }^{25}$ See Donald C. Langevoort, Organized Illusions: A Behavioral Theory of Why Corporations Mislead Stock Market Investors (and Cause Other Social Harms), 146 U. Pa. L. Rev. 101 (1997) [hereinafter Langevoort, Organized Illusions].

${ }^{26}$ See id. at 134.

${ }^{27}$ See id. at 139-41.

${ }^{28}$ See id.

${ }^{20}$ Id. at 121; see also Holman W. Jenkins, Jr., When CEOs Can't Add Up the Numbers, Wall St. J., Aug. 19, 1998, at A19 (discussing recent cases of corporate accounting fraud: "By twisting their heads sideways and indulging in a great deal of wishful thinking, all three CEOs may really liave beheved what they lieard, and even 
On average, this biased screening of data will result in top-level managers operating with skewed information. ${ }^{30}$ Even if they discount the information that they receive from their subordinates, discounting will be imprecise. As a result, the statements that top executives make in press releases or to market analysts may be similarly skewed in a substantial number of cases. ${ }^{31}$ This skewing will occur despite the absence of any intent on the part of the manager to mislead. These defects in information flows are likely to be exaggerated by a tendency to discount adverse developments, commitinent to a plamed course of action, over-optimism about the firm's prospects relative to its rivals, and self-serving beliefs. ${ }^{32}$ While some of these biases may actually enhance corporate performance ${ }^{33}$ the combination of tliese cognitive defects greatly increases the likelihood that corporate managers will inake public statements that distort stock prices. ${ }^{34}$

Finally, there may be some cases where corporate managers make misstatements intended to enhance shareholders' welfare. One example of this phenomenon is Basic, Inc. v. Levinson, ${ }^{35}$ the case in which the United States Supreme Court adopted the fraud on the market presumption. ${ }^{36}$ In that case, Basic's managers falsely

set up their underlings to tell them the story they wanted to hear. We are at the place where wishful thinking shades into fraud.").

${ }^{30}$ See Langevoort, Organized Illusions, supra note 25, at 125 ("Positive information will move more quickly to the top, with the primary problem in assessing it being the possibility of overstatement, and excessive and conflicting claims of credit. Negative information will travel more slowly, if at all, and will be inore subject to skewing. On average, a natural optimistic bias results.").

"See id. ("There is evidence in the literature that semior executives do habitually discount the veracity of information that moves upward, especially when it has a positive spin. But that discount is rough and imprecise, and thus of little aid in achieving disclosure accuracy.").

${ }^{32}$ See id. at 135-49; see also Bershad et al., supra note 23, at 19 ("Soine corporate cultures may simply reward optimism and penalize pessimism (or realism).").

${ }^{33}$ A bias toward optimism or perceived success may lead employees to work more diligently on behalf of a corporation-it is more fun to be part of a winning team. See Langevoort, Organized Illusions, supra note 25, at $155 \mathrm{n.192}$ ("an optimistic culture or subculture may be an agency-cost reduction mechanism").

${ }^{34}$ See id. at 157 ("If corporations habitually tend toward cogmitive conservatism, overcommitunent, overoptimism, and selfisl inference, there is a considerable likelilood that the subjective forward-looking elements of their disclosure and publicity will have the potential to mislead.").

${ }^{35} 485$ U.S. 224 (1988).

${ }^{36}$ The fraud on the market presumption is discussed infra notes $83-88$ and accompanying text. 
denied that they were in merger negotiations with another company. ${ }^{37}$ The managers made these misstatements in an effort to preserve the confidentiality of those negotiations, believing that the merger would be jeopardized if the negotiations were disclosed before the deal had become final. ${ }^{38}$ Insofar as mergers enhance the wealth of shareholders, the misstatements in Basic appear to be welfare enhancing-at a minimum, the managers did not breach their duty of loyalty. The Supreme Court, however, abruptly rejected the arguinent that the securities laws might permit lying that enhances shareholder wealth. ${ }^{39}$ In the Court's view, the securities laws require truthful statements at all times, without regard to the effect of truth on shareholder welfare. ${ }^{40}$ The Supreine Court's view of the statutory requirement aside, it is difficult to assess the efficiencies of allowing beneficial misstatements by corporate managers. Any efficiency conclusion in this regard would require weighing the benefits froin the mergers against the costs of distorted security prices, and which way the balance tips is not obvious. ${ }^{41}$

Ambiguous legal standards governing disclosure ensure that even honest managers will cause some fraudulent omissions. Corporate managers and their counsel assessing the "nrateriality" of a given fact receive little guidance fron the courts. Disclosing a potential problein or opportunity nray look deceptive in hindsight if the event does not come to pass, but omitting that fact will certainly look deceptive if the event does occur. ${ }^{42}$ The inateriality re-

${ }^{37}$ See Basic, 485 U.S. at 227.

${ }^{33}$ See id. at 233.

${ }^{39}$ See id. at 235.

40 See id.

${ }^{41}$ There is a lively debate on this question. Compare Jonathan R. Macey \& Geoffrey P. Miller, Good Fimance, Bad Economics: An Analysis of the Fraud-on-theMarket Theory, 42 Stan. L. Rev. 1059, 1091 (1990) (arguing that managers should be allowed to lie whenever lying is consistent with their fiduciary duties to shareliolders), with Ian Ayres, Back to Basics: Regulating How Corporations Speak to the Market, 77 Va. L. Rev. 945, 947-64 (1991) (arguing that the optimal standard may be a default "no lying" rule that permits opting out).

${ }^{42}$ See Ralpli K. Winter, Paying Lawyers, Empowering Prosecutors, and Protecting Managers: Raising the Cost of Capital in America, 42 Duke L.J. 945, 965 (1993) ("Where the law is defiberately unclear, a corporation cannot know whether it must disclose until a court rules. Moreover, where the law is deliberately unclear, any disclosure made regarding ambiguous events, such as merger negotiations, will arguably be misleading or madequate. The corporation, no matter low simcere its desire to comply with the law, will thus face a costly class action whether it discloses or not, as 
quirement protects the corporation froin having to disclose every potential eventuahity. Materiality determinations, however, are among the most difficult faced by securities lawyers and their chents, and additional disclosures may give the corporation's competitors important information. Disclosure errors are inevitable.

\section{B. Costs}

\section{Reduced Managerial Accountability}

If the agency cost explanations offered above are the prinary sources of corporate misstatements, then fraud on the market innphicates important issues of corporate governance. These sources of fraud by corporate managers are disparate, but they have a common effect: They impair the ability of outside shareholders to momitor the performance of the firm, and, more specifically, the performance of the firm's managers. ${ }^{43}$ Providing shareholders with better tools with which to scrutinize management was one of Congress's central purposes in adopting the Exchange Act. ${ }^{44}$ Insofar as fraud on the market makes it more difficult to scrutinize managerial performance, it may have a significant impact on the market for corporate control. ${ }^{45}$ This reduction in monitoring of corporate

long as a claim of damages sufficient to support a significant award of attorney's fees can be asserted.").

4'See James D. Cox, Compensation, Deterrence, and the Market as Boundaries for Derivative Suit Procedures, 52 Geo. Wash. L. Rev. 745,747 (1984) ("Information asymmetries accompany managerial misconduct: managers know the frequency and amount of harm caused by their misconduct, whereas outside investors do not."). Reductions in liquidity may also diminish managerial accountability. See Jonathan R. Macey \& David D. Haddock, Shirking at the SEC: The Failure of the National Market System, 1985 U. Ill. L. Rev. 315, 326 ("The greater the liquidity of a corporation's shares, the greater the opportunity for the marketplace to express an opinion about corporate management through the buying and selling of shares, thus enabling the market to influence corporation decisions to replace inept or dishonest managers.").

${ }^{4}$ See Jill E. Fisch, From Legitimacy to Logic: Reconstructing Proxy Regulation, 46 Vand. L. Rev. 1129 (1993) (making similar argument with respect to Section 14(a)); Paul G. Mahoney, Mandatory Disclosure as a Solution to Agency Problems, 62 U. Chi. L. Rev. 1047, 1079-80 (1995) [heremafter Mahoney, Mandatory Disclosure] (discussing Congress's intention to reduce agency costs with Exchange Act); Steve Thel, The Gernis of Section 16: Regulating the Management of Publicly Held Compamies, 42 Hastings L.J. 393, 399 (1991) (arguing that $\$ 16$ of the Exchange Act enhances managerial accountability).

4s See Merritt B. Fox, Rethinking Disclosure Liability in the Modern Era, 75 Wash. U. L.Q. 903, 909 (1997) (discussing the role of accurate stock prices in facilitating market for corporate control); Marcel Kahan, Securities Laws and the Social Costs of 
agents must be counted as part of the social costs of misstatements by managers. ${ }^{46}$ Policing corporate disclosure may enhance monitoring of managers, which may increase corporate profitability by reducing agency costs.

\section{Liquidity Costs}

The social costs of fraud go beyond their effect on internal corporate governance. Fraud also affects decisions by mvestors on how to allocate their resources. Understanding how fraud hurts securities markets requires careful analysis of investors' reactions to the existence of fraud.

The cost of fraud is not found in the wealth transfer it effects, but rather in the responses by individuals to that potential wealth transfer. In the classic case of fraud, the person committing the fraud directly benefits from the fraud by transferring wealth from his victim to himself. While the victim suffers an individual cost, the social cost of the transfer is zero because of the offsetting benefit to the fraudster. But this wealth transfer induces the fraudster to spend real resources in executing the fraud and the potential victims to spend real resources to avoid being victimized. ${ }^{47}$ The wealth transfer also induces nonfraudulent sellers to spend real resources establishing their credibility and distinguishing themselves froin fraudsters. Aggregating the fraudster's expenditures in committing the fraud, the nonfraudsters' credibility expenditures, and

"Inaccurate" Stock Prices, 41 Duke L.J. 977, 1036 (1992) ("A stock price above fundamental value... may discourage acquisitions that would increase a company's value.").

${ }^{45}$ See Louis Lowenstein, Financial Transparency and Corporate Governance: You Manage What You Measure, 96 Colum. L. Rev. 1335 (1996) (arguing that financial transparency enhances corporate governance). Another feature of fraud on the inarket's deleterious effect on the market for corporate control is the possibility that inflated stock prices may also allow corporations to acquire other corporations at bargaim prices. These acquisitions inay result in poor managers displacing good ones. Reductions in liquidity may also impair the market for corporate control by making it difficult to assemble a large block of stock in a short period of time. See Paul G. Mahoney, Is There a Cure for "Excessive" Trading, 81 Va. L. Rev. 713, 735 (1995) [hereimafter Mahoney, Excessive Trading].

${ }^{47}$ See Paul G. Mahoney, Precaution Costs and the Law of Fraud in Impersonal Markets, 78 Va. L. Rev. 623, 630 (1992) [hereinafter Mahoney, Precaution Costs] ("If fraud is not deterred, market participants will take expensive precautions to uncover fraud so as to avoid entering into bargains they would not have concluded in an honest market."). 
the potential victim's precaution costs to avoid the wealth transfer, the social costs from the fraud are likely to exceed the victim's loss. ${ }^{48}$ Not surprisingly, the victim's loss is the measure of damages in such cases. ${ }^{49}$ Requiring the fraudster to compensate the victim discourages both the fraudster from investing in fraud and the victim from incurring socially wasteful precaution costs agamst fraud. ${ }^{50}$ It also discourages credibihty expenditures by nonfraudulent sellers who are competing with the fraudster.

The victim's loss is also the measure of damages in fraud on the market cases, ${ }^{51}$ but here that measure does not correlate with the social costs of the fraud. In fraud on the market, for every shareholder who bought at a fraudulently inflated price, another shareholder has sold: The buyer's individual loss is offset by the seller's gam. Assuming all traders are ignorant of the fraud, over time they will come out winners as often as losers from fraudulently distorted prices. ${ }^{52}$ And if the corporation has not been trading in its own securities, the corporation has no gain, and, therefore, no incentive to spend real resources in executing the fraud. Thus, shareholders would not spend resources to avoid fraud on the market, and corporations would not spend resources to commit it. If these assump-

48 See id. at 632 (arguing that wealth transfer can serve as a proxy for investment in lying, precaution costs, and allocative losses where fraud results in a transfer from victim to fraudster). Where precautions are too costly, the investor may simply discount the amount that she is willing to pay to reflect the probability of fraud. Assuming that no sanction is applied to the fraudster, such discounting will lead to the familiar "lemons" problem, where fraudulent investments drive out the good. See George Akerlof, The Market for "Lemons": Qualitative Uncertainty and the Market Mechanism, 84 Q.J. Econ. 488, 494-99 (1970) (arguing that when sellers have greater knowledge than buyers, market collapse may result). This allocative loss is a principal social cost of fraud.

49 See Frank H. Easterbrook \& Daniel A. Fischel, The Economic Structure of Corporate Law 334 (1991).

${ }^{\text {so }}$ See id. at 321 . These precaution costs will be incurred with relation to all firms because investors will have difficulty, ex ante, sorting fraudulent from nonfraudulent firms.

${ }^{51}$ See Sirota v. Solitron Devices, Inc., 673 F.2d 566, 577 (2d Cir. 1982) (allowing the recovery of the difference between the price paid and the security's true value).

s2 See Donald C. Langevoort, Capping Damages for Open-Market Securities Fraud, 38 Ariz. L. Rev. 639, 646 (1996) [hereinafter Langevoort, Cappmg Damages] ("At least active traders with large diversified portfolios have roughly the same chance of being winners.as losers from securities fraud, and over time these gains and losses will tend to net out toward zero even in the absence of hitigation."). I relax the assuinption of equal ignorance below. See infra notes 56-73 and accoinpanying text. 
tions hold, shareholders should have no expected loss from fraud on the market if the fraud is perfectly concealed until disclosure.

To be sure, risk-averse investors who weigh losses more heavily than gains might not take solace in neutral expectations. Such investors might be deterred from participating in the stock market if they believed that stock prices were distorted by fraud. They might invest instead in government-insured certificates of deposit, Treasury bills, or investments from other countries ${ }^{53}$ forcing corporations to resort to the debt inarkets rather than soliciting equity investınents. These altered investment decisions would impose a real cost on the economy by distorting risk-return calculations, resulting in suboptimal resource allocation and risk sharing.

Notwithstanding those concerns, it is unlikely that such risk aversion would affect levels of participation in the securities markets. Through the vehicle of the mutual fund, risk-averse investors can acquire a diversified portfolio of securities at low cost; indeed, such a strategy would cost considerably less than the opportunity cost of avoiding the stock niarket in favor of alternative investments. Holding a diversified portfolio effectively eliminates any possibility of being a net loser froni fraud on the market, thereby assuaging the concerns of even the risk-averse shareholder. ${ }^{54}$ Thus, risk-averse investors should have no incentive to spend real resources to avoid being the victims of fraud on the market because diversification would let thein avoid losses more cheaply than investigation. $^{55}$ Consequently, resource allocation and risk sharing

${ }^{53}$ This assumes that those investments were less likely to be infected by fraud, an unlikely proposition for inost countries coinpared to the United States, which is generally regarded as having the most stringent antifraud enforcement.

${ }^{54}$ See Easterbrook \& Fischel, supra note 49, at 340 ("An investor with a diversified portfoho will be the hidden gainer [fronı fraud on the inarket] as often as he will be a loser. Every losing buyer during the [period affected by fraud] is inatched with a gaining seller. Over the long run, any reasonably diversified investor will be a buyer half the time and a seller half the time.").

ss See Fox, supra note 45, at 908 ("If an investor has a less than fully diversified portfolio, greater share price inaccuracy can make the portfoho inore risky. High quality disclosure would, to some extent, protect such an investor by reducing this risk. The imvestor, however, can protect himself inuch more effectively and at less social cost by simply diversifying inore."); Lyum A. Stout, The Unimportance of Being Efficient: An Econouric Analysis of Stock Market Pricing and Securities Regulation, 87 Mich. L. Rev. 613, 672 (1988) ("[I]f the 'risk' of a mispriced purchase or sale in an inefficient market is diversifiable risk-and there seems to be no reason why it should not be-portfolio investors will not be concerned with it at all."). 
should be unaffected, and fraud on the market would impose minimal social costs.

If this were the entire story, we would conclude that any expenditure spent deterring fraud on the market and compensating its victims is wasted. But the story becomes more complicated when we relax the artificial assumptions that investors simply diversify away the risk of loss from fraud on the inarket and that there are no systematic wealth transfers ainong investors. A passive diversification strategy will be the only option for most investors. But fraud on the market, left unchecked, will induce soine investors to try to beat tlie market by investigating the statements made by the company. ${ }^{56}$ These efforts at verification are likely to be prohibitively expensive for all but the most substantial and sophisticated investors-verification requires specialization. ${ }^{57}$ Informed trad$\mathrm{ers}^{58}$ who are already expending real resources to evaluate a coinpany's stock price, are likely to reallocate some of their efforts froin investigation to verification in the presence of fraud on the market. ${ }^{59}$ Fraud on the market, therefore, creates information asymmetries between traders that would not otherwise exist. These information asymmetries mean potential profits for imformed traders and corresponding losses for the uninformed. Empirical evidence supports the proposition that fraud on the market leads to greater informed trading. ${ }^{60}$ Those potential profits for in-

${ }^{56}$ See Easterbrook \& Fischel, supra note 49, at 335 (arguing that fraud on the market leads imvestors to investigate).

${ }^{5}$ See Daniel R. Fischel, Use of Modern Finance Theory in Securities Fraud Cases Involving Actively Traded Securities, 38 Bus. Law. 1, 13 (1982) [hereinafter Fischel, Modern Finance Theory] (arguing that the presence of market professionals makes investigation by public investors irrelevant because of professionals' advantage in obtaining information).

${ }^{\text {ss }}$ Informed traders are "market professionals, such as arbitrageurs, researcliers, brokers and portfolio managers, who devote their careers to acquiring information and honing evaluative skills." Ronald J. Gilson \& Reinier H. Kraakman, The Mechanisnis of Market Efficiency, 70 Va. L. Rev. 549, 571 (1984).

${ }^{50}$ See Langevoort, Organized Illusions, supra note 25 , at $157 \mathrm{n} .196$ ("Investment analysts and other professional investors can, in many cases, test inanagement's inferences by contacting customers, suppliers, and other experts for alternative points of view about the coinpany's prospects.").

${ }^{*}$ See Patricia M. Dechow et al., Causes and Consequences of Earnings Manipulation: An Analysis of Firms Subject to Enforcennent Actions by the SEC, 13 Conteinp. Acct. Res. 1, 22 (1996) (reporting that short selling begins to increase two inonths before the announcement of earnings manipulation). 
formed traders may induce additional expenditures to flow to market analysis above the level drawn by pure investigation. ${ }^{61}$ That effect is offset, however, by the fact that fraud on the market makes investigation less rehiable and, therefore, less profitable for informed traders. Nonfraudulent statements by corporations unainbiguously enhance the informational efficiency of the markets, and efforts by informed traders to supplement and investigate those statements also enhance informational efficiency. ${ }^{62}$ Efforts at verification, by contrast, are a social waste induced by the misstateinent. Assuming that the truth can be told as cheaply as a lie, all investors would be better off if they could simply rely on corporate statements without further effort at verification.

The social costs of fraud on the market are compounded, however, when we consider the effects of verification on the hquidity of the trading markets. The presence of verifiers in the market is analytically identical to the presence of insider traders. Both verifiers and insider traders are informed traders who hold asymmetric information advantages over uninformed traders. Those asymmetric information advantages lead to trading profits-verifiers and insider traders buy low and sell high. To avoid the corresponding

${ }^{61}$ On the incentives of traders to become informed, see Sanford J. Grossman \& Joseph E. Stighitz, On the Impossibility of Informationally Efficient Markets, $70 \mathrm{Am}$. Econ. Rev. 393, 399-400 (1980) (arguing that the presence of uninformed "noise" traders provides incentives to invest in information).

${ }^{62}$ Whether that informational efficiency translates to overall efficiency is a separate question. See Jack Hirshleifer, The Private and Social Value of Information and the Reward to Inventive Activity, 61 Am. Econ. Rev. 561, 561-62 (1971) (arguing that investments in "foreknowledge" of future states of affairs may provide private, but not social, benefits, leading to overinvestment in information acquisition).

${ }^{63}$ See Gilson \& Kraakman, supra note 58, at 594-95 (discussing verification costs); Stout, supra note 55, at 702 ("Private expenditures by inarket participants trying to identify and trade in mispriced stocks may be a social waste akm to that incurred when the public spends money handicapping and betting on horse races."); see also Michael R. Darby \& Edi Karni, Free Competition and the Optimal Amount of Fraud, 16 J.L. \& Econ. 67, 83 (1973) ("[A] reduction in fraud or mistepresentation requires no additional resources but only a decision to stop."); id. at 85 n.36 ("For publicly owned firms, this guarantee is implicit in the possibility of a 'consuiner advocate' selling the firm's stock short before announcing discovery of fraud. As a result private provision of fraud detection could be greater than the social optimum if the private returns from the short sale are greater than the social returns in resource savings."). It inay not be the case that the truth can be told as cheaply as a he if defects within an organization's information flow prevent corporate spokesmen from having complete access to relevant information. See supra notes 25-34 and accompanying text. 
trading losses, uninformed traders would prefer to trade ouly with other uninformed traders. ${ }^{64}$ Because securities markets are largely anonymous, however, outsiders have no way of knowing when they are trading with an insider. They do know, however, that they will systematically lose when trading with imsiders. ${ }^{65}$ Market makers who supply liquidity to the markets on an uninformed basis will increase their spreads to reflect the possibility of dealing with an insider trader. ${ }^{\circ}$ As a result, insider trading simply becomes a transaction cost of all trading. ${ }^{67}$ Uninformed shareholders will discount the amount that they are willing to pay for shares by their

* This aversion to trading with the informed has been known since the earliest days of organized stock exchanges in the United States. See Robert Sobel, The Big Board 30 (1965) [hereinafter Sobel, The Big Board] ("Since news fronı Europe reached New York first, Manhattan brokers would often rush to Philadelphia in the hope of buying or selling securities whose prices might change when developinents in London or Paris were made known. The appearance of a stagecoach full of New York brokers would cause consternation on Chestnut Street; the Wall Streeters' actions were viewed with suspicion and distrust."). If there are any informed traders at all, however, the uninformed will prefer more informed traders to fewer because coinpetition among the informed will reduce the losses of the uninformed. See Anat R. Admati \& Paul Pfleiderer, A Theory of Intraday Patterus: Volume and Price Variability, 1 Rev. Fin. Stud. 3, 33-34 (1988) ("When informed traders observe highly correlated signals, conipetition between thein is intense, and this improves the terms of trade for liquidity traders, promoting concentration of tradimg.").

${ }^{65}$ See Michael Manove, The Harm fron Insider Trading and Informed Speculation, 104 Q.J. Econ. 823, 826 (1989) ("Insider traders buy at the right time and sell at the right time.... [I]t follows that on the average, outsider traders are being induced to do the opposite.").

${ }^{66}$ See Merton H. Miller, Financial Innovations and Market Volatility 156 (1991) (discussing wider spreads and reduced liquidity caused by informed trading). Coinpanies can reduce the spread in their stock by being nore forthcoming in their disclosure. See Michael Welker, Disclosure Policy, Information Asymmetry, and Liquidity in Equity Markets, 11 Contemp. Acct. Res. 801, 814 (1995) (finding that corporations with disclosure ratings in the top third of sample have a $50 \%$ narrower bid/ask spread than coinpamies in the bottom third). This effect will be especially pronounced for stocks in which there is a high perccntage of informed trading. See id. at 820.

${ }^{67}$ See Lawrence R. Glosten \& Paul R. Milgrom, Bid, Ask and Transaction Prices in a Specialist Market with Heterogeneously Informed Traders, 14 J. Fin. Econ. 71, 72 (1985) (" $[T]$ he specialist faces an adverse selection problem, since a customer agreeing to trade at the specialist's ask or bid price inay be trading because he knows something that the specialist does not. In effect, then, the specialist nust recoup the losses suffered in trades with the well informed by gams in trades with liquidity traders."). 
expected losses from trading with insiders; ${ }^{68}$ they may atteinpt to avoid losses froin trading with insiders by trading less frequently.

Verification leads to similar discounting and reduction in trading by uninformed investors. As with insider trading, uninformed investors are not in a position to verify and they know that they will systematically lose when trading with verifiers. The uninformed can avoid this cost only by trading less frequently. The fixed transaction cost of trading with verifiers is offset by the greater returns on their investment that flow to those who hold their shares for a longer period. ${ }^{69}$ If uninformed investors trade less frequently, a greater proportion of trading volume will be inade up of informed traders, creating an adverse selection problem as more traders exit the market so as to avoid trading with the better informed. ${ }^{70}$ Less tradimg means less liquidity, and less liquid securities markets are less attractive to traders because such markets have higher execution costs for trades. ${ }^{71}$ Thus, one of the primcipal social costs of fraud on the market is a higher cost of liquidity for traders. ${ }^{72}$ This higher liquidity cost will be reflected in lower stock prices generally. ${ }^{73}$

${ }^{6}$ See Frank H. Easterbrook, Insider Trading, Secret Agents, Evidentiary Privileges, and the Production of Information, 1981 Sup. Ct. Rev. 309, 325 (arguing that shareholders will pay less for stock when insider trading is expected).

${ }^{69}$ See Glosten \& Milgrom, supra note 67, at 96-97 (noting that the cost of informed trading is sinaller if amortized over a longer period of time due to greater returns on investinent).

${ }^{70}$ See id. at 74 (describing the adverse selection problem created by the presence of informed traders); see also Nicholas L. Georgakopoulos, Frauds, Markets, and Fraud-on-the-Market: The Tortured Transition of Justifiable Rehance from Deceit to Securities Fraud, 49 U. Miami L. Rev. 671, 707 (1995) (arguing that fraud on the market leads to reduced liquidity). This adverse selection problein means that the overall level of trading is reduced, because the uninformed investors' transaction costs increase inore than the verifiers' reduced transaction costs.

${ }^{71}$ See Dechow et al., supra note 60, at 29 (reporting that bid/ask spreads increase by $0.7 \%$ of the company's stock price after announceinent that coinpany has engaged in earnings inampulation). These higher execution costs are likely to be disproportionately born by the largest, most sophisticated investors. See infra notes 187-93 and accompanying text.

72 See Charles M.C. Lee, Market Integration and Price Execution for NYSE-Listed Securities, 48 J. Fin. 1009, 1014 (1993) (observing that a loss of uuinformed traders may lead to greater quoted spreads and higher liquidity costs).

${ }_{73}$ See Yakov Amihud \& Haim Mendelson, A New Approach to the Regulation of Trading Across Securities Markets, 71 N.Y.U. L. Rev. 1411, 1429 (1996) ("Although the illiquidity costs per transactions are usually sinall relative to the security's price, their effect on the security's value is considerable because the costs are incurred repeatedly whenever the security is traded."). 


\section{Capital Allocation}

Fraud on the market may also harm capital allocation by allowing firms to raise money for investment projects that are not costjustified. Firms tend to mcrease their disclosures during periods in which they plan to issue securities; insofar as those disclosures are fraudulent, imvestors will pay an inflated amount for those securities. ${ }^{74}$ Inflated stock prices in the secondary market obviously have an effect on common stock offerings priced "at the market," but such offerings are a small portion of investment capital. Most projects are financed through internally generated cash flows. ${ }^{75}$ Nonetheless, an inflated stock price may induce shareholders to tolerate a lower dividend than they otherwise might, leaving a larger portion of cash flows subject to managerial discretion. Managers who have fraudulently inflated their stock price may be able to mvest in projects that are not cost-justified, instead of paying cash flows to shareholders in the form of dividends. ${ }^{76}$ Alternatively, if Arlen and Carney's "last period" theory is correct, managers may use fraud to keep the firm im business when its assets should be reallocated to more efficient managers through the bankruptcy process."

\section{COMPENSATION OR DETERRENCE?}

The principal social costs produced by fraud on the market are reduced management accountability, a loss of liquidity in the stock market, and distorted capital allocation. Deterrence plays an important role in reducing these costs. Compensation, by contrast, does little to reduce the costs of fraud on the market. If fraud on the market can, for the inost part, be diversified away, investors' losses froin trades affected by that fraud are not really a social

${ }^{24}$ See Mark Lang \& Russell Lundholm, Cross-Sectional Determinants of Analyst Ratings of Corporate Disclosures, 31 J. Acct. Res. 246, 262 (1993) (finding a statistically significant increase in analysts' disclosure ratings for firms during periods of securities issuance).

${ }^{75}$ See Stout, supra note 55, at 648 ("Operating revenues finance an average of $61 \%$ of corporate expenditures.").

${ }^{76}$ See Merritt B. Fox, Securities Disclosure in a Globalizing Market: Who Should Regulate Whom, 95 Mich. L. Rev. 2498, 2544-45 (1997).

$\pi$ See Michelle J. White, Corporate Bankruptcy as a Filtering Device: Chapter 11 Reorganizations and Out-of-Court Debt Restructurings, 10 J.L. Econ. \& Org. 268, 270 (1994) (discussing social losses caused by failing firms continuing when their assets could be reallocated to more efficient uses). 
cost. $^{78}$ The ability to diversify means that providing compensation for fraud on the market will not have a significant effect on mvestors' behavior-they will continue to invest whether or not compensation is provided to them. ${ }^{79}$ And compensation as a form of insurance makes little sense if the victim of fraud can avoid the risk at a lower cost.

Although the decision to invest will be unaffected, investors may hold securities for longer periods of time in the presence of fraud on the inarket to avoid the higher trading costs associated with the presence of verifiers. Compensation does little to reduce the liquidity losses associated witli verification. Uninformed shareholders are not in a position to verify, so compensation is not necessary to discourage them from becoming verifiers. Compensation would be useful when insiders have traded on the knowledge that the security price was distorted, but the general anonymity of the stock market does not allow coinpensation to be paid to those individuals on the losing end of the trades with insiders. The losing individuals cannot be identified in a cost-effective fashion. ${ }^{81}$ And verifiers cannot be sued at all because they have done nothing wrongthere is no prohibition against uncovering fraud. ${ }^{82}$ Conipensation paid by the corporation does nothing to reduce the trading profits of verifiers, so verifiers will still have an mcentive to spend resources checking corporate statements. And because uninformed investors rarely receive full coinpensation for their losses, they will

${ }^{78}$ Investors cannot diversify away wealth transfers to verifiers, see supra notes $56-$ 64 and accoinpanying text, so changes in investment decisions caused by those wealth transfers must be considered a genuine social cost.

${ }^{79}$ See Langevoort, Capping Damages, supra note 52, at 646-47 ("[R]ational investors will not deinand broad protection from [fraud on the market] ex ante in the form of risk premiums. In other words, an offer of full coinpensation is unnecessary to encourage capital formation efficiently.").

${ }^{\circ}$ See Victor P. Goldberg, Accountable Accountants: Is Third-Party Liability Necessary? 17 J. Legal Stud. 295, 307 (1988) (arguing against hability when potential victims can cheaply diversify: "[T] damages arising from putting too many eggs im the wrong basket.").

${ }^{81}$ The limited damages available ineans that class actions are seldom brought in cases of pure insider trading unaccoinpamied by misstateinents. See Eth \& Dicke, supra note 22, at 103-04. Disgorgenent of the imsiders' unlawful gains would enhance deterrence, but securities class actions seldoin accoinplish this task. See infra notes 133-37 and accompanying text.

\& See Dirks v. SEC, 463 U.S. 646 (1983) (overturning the SEC's censure of an imvestment adviser who uncovered massive fraud). 
still reduce their trading to avoid losses to verifiers. Thus, compensation will do hittle to reduce the loss of liquidity caused by fraud on the market.

Compensation from the corporation also will not ameliorate the problems of reduced managerial accountability and distorted capital allocation. Causing the corporation to transfer wealth to its shareholders will not replace the profits lost due to substandard managerial performance and unjustified investment decisions; it is simply a dividend paid to only a portion of the shareholders (or former shareholders) accompanied by high transaction costs. ${ }^{83}$ Shareholders as a group wonld be further ahead if the resources spent on the lawsuit were simply paid to them as a dividend, without the lawsuit's transaction costs. Deterrence, not compensation, is the answer to the problems of loss of liquidity, reduced managerial accountability, and distorted capital allocation. The next Section evaluates the efficacy of fraud on the market class actions in deterring fraud.

\section{A. Class Actions and the Conflict Between Compensation and Deterrence}

Fraud on the market class actions are brought to compensate investors who have bought their shares for too much, or sold them for too hittle, as a result of fraudulent misstatements by the corporation. As discussed above, however, compensation does little to reduce the social costs of securities fraud-deterrence is much more important in controlling those costs. Notwithstanding the primacy of deterrence, securities class actions subordinate that goal to the competing goal of compensation in a variety of ways. Because they shortchange deterrence, securities class actions are an expensive way to reduce the social costs of fraud on the market.

* See Arlen \& Camey, supra note 10, at 719 ("Although compensating victims may be a laudable goal, enterprise liability does not serve the goal of just compensation because it simply replaces one group of innocent victims with another: those who were shareholders when the fraud was revealed. Moreover, enterprise hability does not even effect a one-to-one transfer between innocent victims: a large percentage of the plaintiffs' recovery goes to their lawyers."). 


\section{Incentives of Plaintiffs' Lawyers}

Class actions are made possible in secondary market fraud cases by the fraud on the market presumption adopted by the Supreme Court in Basic, Inc. v. Levinson. ${ }^{84}$ That presumption replaces the common law requirement of reliance to establish fraud. Most investors would be unable to satisfy the common law reliance requirement in secondary trading markets: They do not bother to monitor regularly corporate disclosures and, therefore, would not have heard the misstatement. Although the Court in Basic treated its adoption of the presumption as primarily a procedural change making securities fraud class actions niore manageable, ${ }^{85}$ the presumption in fact produced an enormous increase in liability exposure for corporate issuers. ${ }^{86}$ While the number of investors who have actually heard and relied on a misstatement emanating fronı the corporation is likely to be small, the class of investors that purchased or sold during the time the market price was affected by the misstatement is likely to be enormous. Given the trading volumes in the securities niarkets today, the value of shares traded during the class period may amount to more than a corporation's total capitalization. ${ }^{87}$ Potential damages awards were increased exponentially by this "procedural" change. Under the fraud on the market presumption, typical damages exposure will be in the tens or hundreds of millions of dollars. ${ }^{88}$ Thus, in order to facilitate compensation, the Suprenie Court vastly expanded corporations' potential liability for misstatements.

This explosion in the size of potential awards had a predictable influence on the plaintiffs' bar. Fraud on the market class actions becanie a cottage industry post-Basic, as plaintiffs' attorneys

84 485 U.S. 224,247 (1988).

ss See id.

\& See Brent Bowers \& Udayan Gupta, Shareholder Suits Beset More Small Companies, Wall St. J., Mar. 9, 1994, at B1 (reporting that total cash settlements from securities class actions increased over 300\% between 1988 and 1992).

${ }^{87}$ See Lynn A. Stout, Are Stock Markets Costly Casinos? Disagreement, Market Failure, and Securities Regulation, 81 Va. L. Rev. 611, 621 (1995) ("In 1992, nearly half of the shares listed on the NYSE changed hands. In the OTC inarket, the dollar volume of trading in NASDAQ-listed stocks amounted to $160 \%$ of the total value of shares listed, implying an average investor holding period of less than eight months.").

\& See Janet Cooper Alexander, Rethinking Danuages in Securities Class Actions, 48 Stan. L. Rev. 1487, 1488 (1996). 
sought compensation for their defrauded chents and, not incidentally, potentially enormous awards of attorneys' fees. ${ }^{89}$ Plaintiffs' lawyers frequently justify fraud on the market class actions as serving both coinpensatory and deterrent functions. The evidence suggests, however, that the limited compensation provided by class actions comes at the expense of deterrence. The high transaction costs and "shotgun" targeting of class actions undermine their deterrent effect.

Class action procedures recreate the "separation of ownership and control" problem so familiar to the corporate governance hiterature. ${ }^{90}$ A diffuse, unorganized group of shareholders owns the claims being asserted in the class action, but the lawsuits themselves are controlled by plaintiffs' lawyers. ${ }^{91}$ As a practical matter, plaintiffs' lawyers face little scrutiny of their performance on behalf of their nominal chents, either from their clients themselves or froin the judiciary. ${ }^{92}$

${ }^{89}$ See Vincent E. O'Brien, The Class-Action Shakedown Racket, Wall St. J., Sept. 10,1991 , at A20 (reporting that the rate at which securities class actions were filed nearly tripled from the date of the Basic decision in 1988 to June 1991).

${ }^{90}$ See, e.g., Adolf A. Berle, Jr. \& Gardiner C. Means, The Modern Corporation and Private Property 119-25 (1933).

${ }^{91}$ See Kamen v. Keinper Fin. Servs., 908 F.2d 1338, 1349 (7th Cir. 1990) ("Securities actions, like many suits under Rule 23, are lawyers' vehicles.... [C]ounsel to whom [the plaintiff] entrusted the hitigation-perhaps more accurately, who found [a plaintiff] to wage the hitigation-is a specialist in the field...."), rev'd on other grounds, 500 U.S. 90 (1991). As one prominent plaintiffs' attorney put it, "I have the greatest practice of law in the world.... I have no chents." William P. Barrett, I Have No Chents, Forbes, Oct. 11, 1993, at 52 (quoting Williain Lerach) (internal quotation marks omitted).

${ }^{92}$ Many of the safeguards that tend to amehorate the problem created by that separation in the corporate context, such as enforceable fiduciary duties or the threat of takeover, are missing from the class action. Even reputation may be a minimal constraint, as plaintiffs' lawyers will generally not be repeat players in any one court, thus reducing the lawyer's incentive to ensure her credibility with the judge. AIthough settlements of class actions are subject to judicial approval, see Fed. R. Civ. P. 23(e), judges do not closely scrutinize settleinents: "[T]he court starts froin the familiar axiom that a bad settlement is almost always better than a good trial." In re Warner Cominunications Sec. Litig., 618 F. Supp. 735, 740 (S.D.N.Y. 1985), aff'd, 798 F.2d 35 (2d Cir. 1986). The problem of judicial disinterest in settlements is exacerbated by the skewed information that judges receive: Settlements are supported before the court by both plaintiffs' and defendants' counsel. See Jonathan R. Macey \& Geoffrey P. Miller, The Plaimtiffs' Attorney's Role in Class Action and Derivative Litigation: Economic Analysis and Recominendations for Reform, 58 U. Chi. L. Rev. 1, 46 (1991) ("[S]ettlement hearings are typically pep rallies jointly orchestrated by 
This lack of scrutiny leaves the class particularly susceptible to overreaching by plaintiffs' attorneys, which ineans that shareholders may receive only a small percentage of their recoverable damages. ${ }^{93}$ More to the point, large attorneys' fees impose high transaction costs on shareholders. ${ }^{94}$ Other mechamisms intended to ahign plaintiffs' lawyers' incentives with their clients' interests work imperfectly in this context. Plamtiffs' lawyers work on a contingent percentage basis, which creates an incentive for them to work hard

plaintiffs' counsel and defense counsel. Because both parties desire that the settlement be approved, they have every incentive to present it as entirely fair."). Defendants are only interested in buying their way out of the litigation; they have no particular interest in low the paynent is divvied up between investors and their lawyers. See Frederick C. Dunbar \& Vinita M. Juneja, Making Securities Class Actions More Responsive to the Modern Shareliolder, in Securities Class Actions, supra note 23 , at 181,184 ("By the time fees are recommended, defendants have already agreed to the settlement and do not care how it is divided among the shareholders and their attorneys."). The adversary systein breaks down at this poimt, and judges are left with a one-sided picture of the settlement's benefits to shareholders and of the performance of their attorneys. See Allegheny Corp. v. Kirby, 333 F.2d 327, 346-48 (2d Cir. 1964) (Friendly, J., dissenting) ("Once a settlement is agreed, the attorneys for the plaintiff stockholders link arms with their former adversaries to defend the joint handiwork."), aff'd per curiam, 340 F.2d 311 (2d Cir. 1965) (en banc).

${ }^{93}$ See Willard T. Carleton et al., Securities Class Action Lawsuits: A Descriptive Study, 38 Ariz. L. Rev. 491,500 tbl.3 (1996) (reporting study showing that $24.1 \%$ of settlements recovered at least one-half of estimated dainages, $19.3 \%$ recovered onefourth of estimated dainages, and $31.8 \%$ recovered less than $10 \%$ of estimated damages); Elliot J. Weiss \& John S. Beckerman, Let the Money Do the Moritoring: How Institutional Investors Can Reduce Agency Costs in Securities Class Actions, 104 Yale L.J. 2053, 2065 (1995) ("The conflicts of interest inherent in such actions lead some plaintiffs' attorneys-critics would say most-to give considerable weight to their interest in maximizing their fee income when deciding on what terms to settle class actions."). Other studies have shown even more limited recovery. See James D. Cox, Making Securities Fraud Class Actions Virtuous, 39 Ariz. L. Rev. 497, 501 (1997) ("The most comprehensive study of settlements before Congress was the study by the National Economic Research Associates, Inc. (NERA) of 254 settlements between 1991 and 1993, finding that, for cases im which investor losses were calculated, the median payment to class inembers was $5 \%$ of their losses."). That study, however, substantially overestimates recoverable losses because it does not account for defenses that might reduce recovery. See id. at 502 n.17.

r Compensation is further undermined by the fact that sinall claimants are less likely to make claims against the settlement fund because their potential recovery is not worth the trouble. See Weiss \& Beckerman, supra note 93, at 2091 ("Investors with small claims no doubt file less often, because at some poimt the costs involved in filing a proof of claim will exceed the amount an investor is likely to recover. In contrast, it seems likely that institutional investors with sizable losses almost always file."); Janet Cooper Alexander, The Value of Bad News in Securities Class Actions, 41 UCLA L. Rev. 1421, 1450 (1994) (reporting that institutional imvestors received $45.9 \%$ of distributions in a sainple of 83 cases). 
to obtain a settlement for their clients. ${ }^{95}$ Unfortunately, the ahgnment of interest created by the contingent percentage fee is not perfect: It also drives a wedge between the attorney's imterests and those of her clients. Because plaintiffs' lawyers receive only a fraction of every dollar recovered, they are likely to underinvest im class actions. ${ }^{96}$ Plaintiffs' lawyers will generally be better served by diversifying their portfolio of lawsuits rather than tying up too many resources in any one suit. Even if that one suit has the strongest evidence of fraud, focusing enforcement resources on that particular suit requires the plaintiffs' lawyers to bear the risk that they will come away with nothing from their mvestment. ${ }^{97}$ The contingent percentage fee also discourages plaintiffs' lawyers from bringing suit in cases where the damage recovery will be too small to justify their fees, even if the evidence of fraud is strong. ${ }^{98}$ For this reason, coinpamies with small capitalizations or trading volume

${ }^{95}$ See 15 U.S.C. § 78u-4(a)(6) (Supp. III 1997) (limiting attorneys' fees awards to a reasonable percentage of the class's recovery). While some courts purport to award attorneys' fees based on a lodestar with an appropriate multiplier for risk, those awards "just liappen to yield fee awards of about 25 to 30 percent of the recovery most of the time." Janet Cooper Alexander, Do the Merits Matter? A Study of Settlements in Securities Class Actions, 43 Stan. L. Rev. 497, 541 (1991).

95 See Macey \& Miller, supra note 92, at 17-18 ("[T]he contingent fee ... gives the attorney an imcentive to pay imsufficient attention to cases where the marginal return to the attorney's time is low relative to other cases in the attorney's portfolio, and to settle early for a lower amount than the attorney could obtain for the client by putting more time and effort into the case."). Class actions frequently "piggy back" on government enforcement actions; the government does the investigation, while the plamtiffs' attorney files the claims in hopes of getting a fee with minimal effort. See John C. Coffee, Jr., Understanding the Plaintiff's Attorney: The Implications of Economic Theory for Private Enforcement of Law Through Class and Derivative Actions, 86 Colum. L. Rev. 669, 681 (1986) ("As an entrepreneur who is compensated only when successful, the plaintiff's attorney bears the costs of failure and seeks to minimize those costs by free-riding on the mountoring efforts of others."). The Reforn Act limits this practice. See 15 U.S.C. \& 78u(d)(4) (Supp. III 1997) (prohibiting the payment of attorneys' fees from funds obtained im an SEC disgorgement action).

${ }^{97}$ See Coffee, supra note 96, at 704-12 (discussing diversification strategy for plaintiffs' attorneys); Alexander, supra note 95, at 547 (“[P]laintiffs' firms may find it more economic to maintain a large portfolio of cases, spending sufficient time and effort on eacl to manage it througl a routinized motion, discovery and settlement process leading to a uniform settlement for a guaranteed fee than to concentrate on intensive preparation of a few cases for trial.").

\$ See Macey \& Miller, supra note 92, at 24 ("The plaintiffs" attorney faces a distribution of cases in which one tail-representing cases where the expected payoff to the attorney falls short of the attorney's expected costs--is cut off."). 
may be effectively immune from the threat of a class action suit. ${ }^{99}$ Finally, given their substantial pre-trial imvestment, plaintiffs' attorneys may be teinpted to settle good cases for too little. Having advanced the costs of litigation, they may be unwilling to risk going to trial and coming away with nothing. ${ }^{100}$ A settlement provides them with a certain fee, while the inarginally greater fee that they could collect after trial has to be heavily discounted for the risk of losing at trial. ${ }^{101}$

In sum, the ability of plaintiffs' lawyers to extract an excessive share of settlements means that class actions impose high transaction costs on shareholders, while fostering limited deterrent value as a result of plaintiffs' lawyers' aversion to pursuing good claims to trial, or pursuing small claims at all.

\section{Defendants' Incentives}

Defendants' incentives to settle make a diversification strategy profitable for plaintiffs' attorneys. If the plaintiffs can withstand a motion to dismiss, defendants generally will find settlement cheaper than litigation. Under the American rule, prevailing defendants are not entitled to their fees and expenses, so even weak cases can be a paying proposition for plaintiffs' attorneys. Any case plausible on the pleadings will have a positive settlenent

9 In addition, the fraud on the market presumption only applies to markets that are informationally efficient. For this reason, the presumption generally will not apply to the less liquid segments of the over-the-counter market, sucl as the NASDAQ Bulletin Board or the Pink Slreets. See Binder v. Gillespie, No. 97-35943, 1999 WL 170162 , at $* 4$ (9th Cir. Mar. 30, 1999) (holding that the fraud on the market presumption does not apply to "pink sheets" because the inarket was not informationally efficient).

${ }^{100}$ See Avery, supra note 6, at 372 ("[C]lass counsel usually advances the costs of litigation, which means that counsel may have a greater incentive than the members of the class to accept a settlement that provides a significant fee and eliminates any risk of failure to recoup funds already invested in the case.").

${ }^{101}$ See Winter, supra note 42, at 950 ("Once a settleinent offer with a significant fee is on the table, the teinptation for plaintiffs' counsel to settle is powerful. A larger recovery may be possible, but the percentage of the increase going to counsel fees is likely to diminish. Moreover, further proceedings will impose substantial out-ofpocket costs on plaintiffs' counsel, who will generally be financing the case."); Coffee, supra note 96 , at $687-90$ (discussing plaintiffs' attorney's incentive to settle prematurely). 
value if only to avoid the costs of discovery and attorneys' fees, which can be substantial in these cases. ${ }^{102}$

Litigation costs will be high because the nost commonly contested issue will be the defendant's state of mind at the time he inade the alleged misstatements, and the only helpful sources will be documents in the company's possession. ${ }^{103}$ Producing all of the documents relevant to the knowledge of a company's semior executives over an extended class period of many inonths, or even years, can be a nassive undertaking. ${ }^{104}$ Having produced the documents, the defendant company can then anticipate a seemingly endless series of depositions, as plaintiffs' counsel seeks to determine whether the executives' recollections square with the documents. ${ }^{105}$ The cost of lost productivity may dwarf the expense of attorneys' fees. ${ }^{106}$ Beyond the cost of executives' time, the mere existence of the class action may disrupt relationships with supphiers and cus-

${ }^{102}$ See Joseph A. Grundfest, Why Disimply?, 108 Harv. L. Rev. 727, 741 (1995) ("A defendant always has an incentive to settle a case for an amount less than avoidable defense costs because any such settlement is less costly than pursuing the case to verdict and prevailing at trial."); see also Dale E. Barnes, Jr. \& Constance E. Bagley, Great Expectations: Risk Management Through Risk Disclosure, 1 Stan. J.L. Bus. \& Fin. 155, 156-57 (1994) (describing a corporation's costs of responding to a securities class action).

${ }^{103}$ See Sherrie R. Savett, The Merits Matter Most and Observations on a Changing Landscape Under the Private Securities Litigation Reform Act of 1995, 39 Ariz. L. Rev. 525, 526 (1997) ("Many cases tum on what the corporate executive officers really knew about the company's financial position during the fraud period. Where plaintiffs can demonstrate through documentation a knowledge of corporate problems and a divergence between what individual officers knew and what the corporation pubhicly said, plaimtiffs will be able to negotiate a greater settlement relative to damages.").

${ }^{10}$ See John F. Olson et al., Pleading Reform, Plaintiff Qualification and Discovery Stays Under the Reform Act, 51 Bus. Law. 1101, 1112-13 (1996) (describing discovery request to which defendant corporation produced 1,500 boxes of documents); $\mathrm{cf}$. Savett, supra note 103, at 526 ("Knowledge can sometimes be shown through a 'smoking gun,' but more often will be demonstrated through regularly generated corporate reports which numerically or textually show a negative trend different froin what has been pubhicly portrayed."). Plaintiffs' expenses im propounding such discovery requests will be dramatically less than defendants' costs in responding. See Alexander, supra note 95 , at 548-49 (discussimg asymmetric hitigation costs in securities class actions).

${ }^{105}$ Weiss \& Beckerman, supra note 93 , at 2086-87.

${ }^{106}$ See Phillips \& Miller, supra note 22, at 1028 ("Officers, directors, and employees of companies are sidetracked from focusing on their core activities. Corporate officials must spend untold hours in a variety of hitigation exercises that otherwise could be devoted to productive uses."). 
tomers, who may be somewhat leery of dealing with an accused fraudster. ${ }^{107}$ Thus, the Supreme Court has recognized that securities fraud suits pose "the threat of extensive discovery and disruption of normal busmess activities."108

The measure of damages required by the goal of compensation reinforces the defendants' inclination to settle, even when the plaintiffs' case is weak. As discussed above, the losses to the victims of fraud on the market are entirely offset by the gains to individuals on the other side of the trade. ${ }^{109}$ In contrast, damages are measured by the difference between the price paid by the victim and the security's "true" value. There is no offset for the wimdfall gain on the other side of the trade. The amount of damages in fraud on the market cases can be enormous for actively traded securities. ${ }^{110}$ Given this downside risk, settlement looks like an attractive option for companies, even when they beheve their prospects of prevailing are good. ${ }^{111}$ Defendants' inclination to settle gives plamtiffs' lawyers an incentive to file even weak cases. ${ }^{112}$

Uncertainty over the standard for hability adds to the settlement imperative. Sorting fraud from mere business reversals is difficult.

${ }^{107}$ See id. (describing collateral costs to corporation's business froin being a securities fraud defendant).

${ }^{103}$ Blue Chip Stamps v. Manor Drug Stores, 421 U.S. 723, 742-43 (1975).

${ }^{109}$ See supra text accoinpanying notes $51-52$.

${ }^{110}$ See, e.g., Court Approves \$115.5 Million Accord In Philip Morris Shareholder Litigation, 30 Sec. Reg. \& L. Rep. (BNA) 1658 (Nov. 20, 1998). There is also likely to be substantial dispute over that volume of trading, as the damages measure needs to be adjusted to reflect investors who both bought and sold during the class period. Existing methodologies provide only the roughest guess as to the proportion of "in and out" investors. See Alexander, supra note 94, at 1424-27, 1458-62 (discussing uncertainty over ineasure of damages im fraud on the market cases).

${ }^{111}$ See Alexander, supra note 88, at 1511 ("The class-based compensatory damages regime in theory imposes remedies that are so catastrophically large that defendants are unwilling to go to trial even if they believe the chance of being found liable is sinall.").

${ }^{112}$ On the subject of incentives to bring nonmeritorious cases, see Lucian A. Bebchuk, Suing Solely to Extract a Settlement Offer, 17 J. Legal Stud. 437, 448 (1988); Avery Katz, The Effect of Frivolous Lawsuits on the Settlement of Litigation, 10 Int'l Rev. L. \& Econ. 3, 14 (1990); D. Rosenberg \& S. Shavell, A Model in Which Suits Are Brought for Their Nuisance Value, 5 Int'l Rev. L. \& Econ. 3, 9-10 (1985). There are few sanctions for filing weak cases: Rule 11 sanctions are virtually never imposed. A notable exception to this general rule is the $\$ 45$ million jury verdict awarded against Millberg, Weiss, Bershad, Hynes \& Lerach for abuse of process. See Richard B. Schmitt, Plaintiffs' Lawyer Lerach and Firm Ordered to Pay \$45 Million in Damages, Wall St. J., Apr. 13, 1999, at B12. 
The external observer may not know whether a drop in a company's stock price is due to a prior misstatement about the company's prospects-fraud-or a risky business decision that did not pan out-bad luck. ${ }^{113}$ Unable to distinguish between the two, plaintiffs' lawyers are forced to rely on the limited publicly available objective indicia in deciding whether to sue. ${ }^{114}$ Thus, a substantial drop in stock price following previous optimistic statements may well lead to a lawsuit. ${ }^{11}$

The scienter standard-what did the defendants know at the time of the misstatement-is the primary means by which the courts sort fraud from nonfraud, but that standard is notoriously amorphous. ${ }^{116}$ It is somewhat more stringent than negligence, but, even in theory, it is difficult to say how much more, and, in practice, it is nearly impossible. ${ }^{117}$ Both knowingly false statements and unfortunate business decisions create a risk of hability, and, thus, an imperative for settlement. If both weak and strong cases lead to settlements, and if the settlements are not substantially greater in strong cases, the deterrent effect of class actions is diluted. ${ }^{118}$

Agency costs also may lead defendants to settle weak cases. Plaimtiffs' lawyers generally sue a corporation's officers as well as the firm itself. Facing personal liability that could potentially bank-

${ }^{113}$ Dunbar \& Juneja, supra note 92, at 183 ("It is not an appropriate task of securities class actions to challenge bad business decisions, if they were arrived at honestly.").

${ }^{114}$ See Eth \& Dicke, supra note 22, at 111 ("Many plaintiffs' attorneys look for a convergence of three factors in determining whether there is a good securities fraud case: (1) optimistic statements by management; (2) a subsequent disclosure of 'bad news' about the prospects of the coinpany that causes a sharp stock price drop; and (3) stock sales by insider during the time management made the allegedly misleading optimistic statements.").

${ }^{115}$ See Grundfest, supra note 102, at 735 ("If the legal systein cannot accurately distinguish certain types of honest volatility from volatility caused by fraud, then plaintiff's counsel have a rational and legal incentive to sue issuers who are innocent of fraud but who will have a hard time proving that fact.").

${ }^{116}$ See Langevoort, Capping Danages, supra note 52, at 644 (discussing annbiguities in scienter standard).

${ }^{117}$ See Mahoney, Precaution Costs, supra note 47, at 650-51 (arguing that the line between negligence and intent $\mathrm{m}$ securities fraud has become blurred); see also A.C. Pritchard, O'Melveny \& Myers v. FDIC: Imputation of Fraud and Optimal Momitoring, 4 Sup. Ct. Econ. Rev. 179, 198 (1995) (arguing that expansion of fraud to include omissions has blurred the boundaries of fraud).

${ }^{118}$ See Avery, supra note 6, at 373 ("To the extent the current systein fails to distinguish adequately between strong cases and weak cases, it serves neither the function of efficiency nor the goal of fairness effectively."). 
rupt even a wealthy individual, corporate officers are understandably reluctant to go to trial. ${ }^{119}$ Directors' and officers' ("D\&O") insurance pays a portion of settlements, and the corporation pays the remainder. ${ }^{120}$ Newer D\&O policies reflect the company's exposure by providing coverage to the company as well its officers. ${ }^{121} \mathrm{D} \& \mathrm{O}$ insurance pays for settlements because a refusal to pay could expose the insurer to potential liability for bad faith refusal to settle. ${ }^{122}$ The insurer would not be compelled to pay, however, when intentional wrongdoing by the covered party has been establislied-a fraud judgment would be outside the coverage of most D\&O policies. ${ }^{123}$ Intentional wrongdoing is also likely to be beyond the corporation's indemnification authority in most states. ${ }^{124}$ The Securities and Exchange Commission ("SEC") also takes the

${ }^{119}$ See Phillips \& Miller, supra note 22, at 1015 ("Individual defendants in class action suits were particularly risk averse and prone to settle. For them, going to trial, even with a strong defense, ran the risk, however sliglt, of a personally ruinous damage award."); Alexander, supra note 95, at 530 (arguing that plaintiffs' lawyers name individual defendants in order to increase risk aversion of defendants as a group in order to encourage settleinent).

${ }^{120}$ See Savett, supra note 103, at 527 ("Where the corporate defendant is solvent, in most instances it contributes to a settlement anywhere from $10-50 \%$ of the ultimate ainount agreed to, usually at the insistence of the insurance carrier."); Alexander, supra note 94 , at $1444-45$ (finding that D\&O insurance typically accounts for $50-80 \%$ of settleinents in IPO cases, with issuers paying 25-50\%).

${ }^{121}$ See Gary Slep, The New D\&O Liability Policy Allocation Options for Securities Claims: Are They Helpful or Do They Only Add to the Confusion?, 9 Corp. Analyst 20,21 (1997) (discussing new policy option covering corporate securities claims). These policies reduce the conflicts between corporations and insurers in allocating responsibility for the settlement. See id. at 22.

122 See Alexander, supra note 95, at 533 ("The insurer cannot liglitly refuse to fund a settlement because it could be subject to a claim for bad faith refusal to settle, which could make it liable for the entire amount of any eventual judgment, without regard to the policy limits."); see also id. at 560-66 (discussing insurers' incentives to settle).

${ }^{123}$ See Coffee, supra note 96 , at 715 ("[A]s a matter of both law and insurance contract provisions, insurance does not cover liability for fraud or unfair self-dealing."); Clifford G. Holderness, Liability Insurers as Corporate Momitors, 10 Int'l Rev. L. \& Econ. 115, 117 (1990) ("[L]iability insurance does not cover obvious conflicts of interest, willful misconduct, or acts the accused slionld have known were illegal."); see also Joseplr P. Monteleone \& Nicholas J. Conca, Directors and Officers Indemnification and Liability Insurance: An Overview of Legal and Practical Issues, 51 Bus. Law. 573, 598-99 (1996) (excerpting typical D\&O policy exclusions).

${ }^{124}$ See, e.g., Del. Code Ann. tit. 8, \& 145 (Supp. 1998) (permitting indemnification only if defendant acted in good faith); see also Monteleone \& Conca, supra note 123, at 580-83 (discussing the scope of indemnification under Delaware law). 
position that indemnification for securities fraud violations is void as against public policy. ${ }^{125}$ Thus, individual corporate officers found liable for a fraud judgment would have a hard time shifting that liability to the corporation. ${ }^{126}$ But settlements are nearly universal, ${ }^{127}$ and they allow the officers to avoid a finding of intentional wrongdoing. ${ }^{128}$ Without such a finding, the D\&O insurer will be compelled to pay the claim. ${ }^{129}$ As a result, officers and directors are usually able to walk away without paying anything. ${ }^{130}$ Because the corporation pays for the insurance, shareholders are effectively paying for class action settlenents, with a portion of those shareholders receiving the proceeds, minus the expense of attorneys' fees. ${ }^{131}$ The transaction costs of litigation leading to settlements that merely transfer wealth among shareholders are a pure social

${ }^{12 s}$ See 17 C.F.R. $\$ 229.512(h)(3)$ (1998); see also Eichenholtz v. Brennan, 52 F.3d 478, 483 (3rd Cir. 1995) (stating that "indemnification runs counter to the policies underlying the 1933 and 1934 Acts"); Alexander, supra note 95, at 555 n.238 (collecting cases in which courts have denied indemnification for securities fraud as contrary to public policy).

${ }^{126}$ See Alexander, supra note 95, at 556 ("It is not just a matter of low much money inay be lost ... but of whose inoney. The individual defendants can settle the case with other people's noney (that of the insurer and the conipany), but will have to pay any adverse judgment and all of their legal fees with their own money. Settlenent is costless to the mdividual decisionmakers personally, but trial presents a risk of enormous personal hability.").

${ }^{127}$ See id. at 525.

${ }^{123}$ See Coffee, supra note 96 , at 715-16 ("The defendants will avoid being 'adjudicated' to have breaclied a duty and can characterize the nature of the habilities so as to permit insurance to cover these payments."). Courts permit indemnification for settleinent payments. See Raychem Corp. v. Federal Ins. Co., 853 F. Supp. 1170, 1177 (N.D. Cal. 1994) (holding that indemnification for settlement costs of a Rule $10 \mathrm{~b}-5$ action was permissible).

${ }^{120}$ See Roberta Romano, The Slrareloolder Suit: Litigation without Foundation?, 7 J.L. Econ. \& Org. 55, 57 (1991) ("Pohicies routinely exempt losses from adjudication of dislonesty, but if a claim is settled, courts prohibit imsurers from seeking an adjudication of guilt and thereby avoiding the claim's payment.").

${ }^{130}$ See Cox, supra note 93, at 509 ("[R]esponsible officers and directors only rarely contribute to the recovery."); Langevoort, Organized Illusions, supra note 25 , at 114 $\mathrm{n} .45$ (reporting results from study slowing that officers and directors pay $0.4 \%$ of the average settlement payment); see also Savett, supra note 103, at 527 ("Plaintiffs' counsel will often settle with officer and director defendants who are usually the most culpable defendants within policy limits because there is hittle incentive to refuse a bird in the land and go outside pohcy limits.").

${ }^{131}$ See Arlen \& Carney, supra note 10, at 699-700 ("Enterprise hability ... imposes most of the cost of fraud on shareliolders who were not responsible for, and received no benefit, from the fraud."). 
waste, unless class actions provide a substantial deterrent effect. ${ }^{132}$ But for the reasons discussed above, class actions offer, at best, a very imprecise and expensive form of deterrence.

Deterrence is further undermined by the fact that the settlement process effectively creates a scheme of exclusively vicarious corporate liability. If the agency cost explanations for fraud on the market are correct, settlements target the wrong party for sanctions. The most substantial motivations for securities fraud involve misstatements by corporate managers that benefit the managers rather than the corporation. ${ }^{133}$ The revelation of the fraud and subsequent lawsuit may lead to the firing of the offending manager in soine cases, ${ }^{134}$ but that sanction is simply the adverse outcome that the manager was seeking to avoid in the "last period" situation identified by Arlen and Carney. ${ }^{135}$ Thus, if termination is the only sanction, and that sanction is apphed in only a percentage of cases, fraud may still be a gamble worth taking for the corporate manager-she would likely find herself out of work in any event if she did not commit the fraud. Likewise, if insider trading was the motivation for the misstatement, a settlement paid by the corporation

\footnotetext{
${ }^{132}$ See id. at 700 (class action settlements produce "a wealth transfer from one group of diversified investors to another, with a substantial deduction for litigation costs, a result no investor would prefer ex ante"); Mahoney, Precaution Costs, supra note 47, at 636 ("Note that a redistribution among shareholders that does not enhance deterrence is every bit as bad as fraud itself. Just as fraud may lead to investments in lying and precautions, so the possibility of using litigation as a purely redistributive tool will lead to excessive investment in litigation."). But see Sanjai Bhagat et al., Managerial Indemnification and Liability Insurance: The Effect on Shareholder Wealth, 54 J. Risk \& Ins. 721, 726 (1987) (arguing that D\&O insurance "induces shareholders to provide momitoring services (through suit and corresponding scrutiny)").

${ }_{133}$ See supra notes 13-24 and accompanying text.

${ }^{134}$ In a sample of firms sued for securities fraud between 1991 and 1998, Philip Strahan found that CEO turnover went from $9 \%$ in the year before the class action was filed to $23 \%$ in the year after filing. See Philip Strahan, Securities Class Actions, Corporate Governance and Managerial Agency Problems 25-26 (June 1998) (unpublished manuscript, on file with the Virginia Law Review Association). Chive Lennox, however, found ouly weak support for an association between CEO turnover and inodified audit reports for a sample of financially-distressed British firms. See Clive S. Lennox, Modified Audit Reports, Executive Compensation and CEO Turnover 18 (1999) (unpublished manuscript, on file with the Virginia Law Review Association). Lennox found stronger support for diminished CEO compensation after a modified audit report. See id. at 14-17.

135 See Arlen \& Carney, supra note 10, at 691, 693, 703.
} 
does nothing to disgorge the insider's ill-gotten gains. ${ }^{136}$ Failing to sanction the wrongdoers responsible for the fraud ineans that the threat of a class action lawsuit does hittle to deter those wrongdoers. ${ }^{137}$

The settlement dynamic in securities class actions fatally undermines the deterrent value of such suits. The cost of litigating securities class actions, tied to potentially enormous judgments, ensures that even weak cases will produce a settlement if they are not dismissed before trial. And the difficulty in assessing the merits of a lawsuit by looking at the complaint means that a substantial number of weak cases will make it through to a settlement. The percentage of securities fraud suits settling for nuisance value testifies to the weakness of judicial procedures as a screening device. ${ }^{138}$ For these reasons, settlements may do a poor job of sorting strong claims of fraud froin nonfraudulent statements, proved wrong only in hindsigltt. Moreover, wrongdoing managers are unlikely to be sanctioned even when tliere is strong evidence of tlieir responsibility for tlie fraud. In sum, class action lawsuits are unlikely to deter if they do not distinguish fraud froin nonfraud and if they allow wrongdoing managers to go unsanctioned.

\section{B. The Private Securities Litigation Reform Act}

Congress attempted to reduce the likelihood that securities class actions would target innocent conduct by enacting the Private Securities Litigation Reform Act. The Reform Act adopted a series

${ }^{136}$ See Weiss \& Beckerman, supra note 93, at 2067-71 (discussing approval of settlement in which CEO paid nothing toward settlement despite strong evidence of imsider trading); Coffee, supra note 96, at 719 ("This pattern of transmuting individual liability into corporate liability can even arise in class actions that essentially allege insider trading by corporate executives. Notwithstanding the clear hability of the imdividual defendants, the great bulk of the settlement fund can come from their corporate employer, which may not have traded but whicli will also be sued under Rule $10 \mathrm{~b}-5$ for making misleading public disclosures.").

${ }^{137}$ Mahoney, Precaution Costs, supra note 47, at 635 ("A $10 \mathrm{~b}-5$ judgment, which simply transfers wealth among shareliolders (and from sliareholders to lawyers), clearly will not deter managers.").

${ }_{138}$ Grundfest, supra note 102 , at $742-43$ (reporting results of studies finding that between $22 \%$ and $60 \%$ of securities suits are settled for nuisance value); Carleton et al., supra note 93, at 511 (finding "smaller settleinents/damages ratios for cases in which settlements were less than $\$ 2$ million, which is consistent with the presence of nuisance suits settled on the basis of plaintiffs' attorney's expenses rather than on the economic damages suffered by plamtiffs"). 
of procedural obstacles to securities fraud class actions in an effort to discourage frivolous actions. ${ }^{139}$ If the Reform Act discouraged only frivolous suits, it could reduce the enormous transaction costs of fraud on the market suits, thereby producing deterrence at a lower cost. But the procedural obstacles of the Reform Act do not screen out only frivolous suits: Instead, the Reform Act makes it harder to bring class actions, whatever their individual merit. The two provisions erecting the inost significant barriers to class actions are the Reform Act's heightened pleading standards for fraud complaints and its stay of discovery while a motion to dismiss is pending.

The pleading standards require plaintiffs to state with particularity facts giving rise to a "strong inference" that the defendant acted with the required state of mind. ${ }^{140}$ Moreover, where a complaint alleges that the defendant misrepresented or omitted to state a material fact, the plaintiff inust specify each statement alleged to have

${ }^{139}$ One reform conspicuously missing froin the Reform Act is the English Rule for attorneys' fees, which would enhance the deterrent accuracy of fraud on the inarket class actions by giving compamies a greater incentive to resist meritless claims. See A. Mitchell Polinsky \& Daniel L. Rubinfeld, Does the English Rule Discourage LowProbability-of-Prevailing Plaintiffs?, 27 J. Legal Stud. 141, 157 (1998) (English Rule encourages lower settlement offers in weak cases). While a "loser pays" provision was included in the original House version of the bill, see Avery, supra note 6, at 348 (discussing "loser pays" provision of H.R. 10), it was omitted due to fears that it would deter sinall shareholders froin filing suit. There are other reasons to be concerned about the Englisl Rule in this context: The Englisl Rule inay imcrease expenditures on attorneys because of the externality problem that it creates. See Avery Katz, Measuring the Demand for Litigation: Is the English Rule Really Cheaper?, 3 J.L. Econ. \& Org. 143 (1987). Given that D\&O insurance now pays for attorneys' fees, it is unclear that the English Rule would worsen the externality problem. See Roinano, supra note 129 , at 57 ("Because D\&O insurers reimburse both sides' expenses in a settleınent, unlike other civil litigation, in sharelıolder suits neither party internalizes litigation costs."). High-probability-of-prevailing litigants will tend to run up large fees under either regime. On the other hand, the English Rule may discourage low-probability-of-prevailing suits, thereby reducing transaction costs. See Amy Farmer \& Paul Pecorino, A Reputation for Being a Nuisance: Frivolous and Fee Shifting in a Repeated Play Gane, 18 Int'l Rev. L. \& Econ. 147 (1998) (denonstrating that fee shifting inay deter frivolous suits when attorneys filing suit are repeat players); Edward A. Snyder \& Janies W. Hughes, The English Rule for Allocating Legal Costs: Evidence Confronts Theory, 6 J.L. Econ. \& Org. 345, 377-78 (1990) (reporting results from empirical study of application of Englisl Rule in Florida from 1980 to 1985).

${ }^{140}$ See 15 U.S.C. $\$ 78 u-4(b)(2)$ (Supp. III 1997). 
been misleading and the reasons why the statement is misleading. ${ }^{141}$ Finally, if an allegation is made on information and belief, the plaintiff must state with particularity all facts on which the belief is formed. ${ }^{142}$ These standards are a substantial departure from the "notice pleading" ordinarily required by the Federal Rules of Civil Procedure, ${ }^{143}$ and they give the judge a much greater role in deciding the merits of the lawsuit tlian is typically exercised under the Federal Rules. The motion to dismiss becoines a substantive challenge to the merits of the lawsuit. If claims of fraud are not plausible on the face of the complaint, they will be dismissed. Given the near universality of settlements (and the incentive structure tliat dominates those settlements), this shift of decisionmaking from the jury to the judge may inake sense. Judicial determination of the merits of securities lawsuits may be tlie only effective means of avoiding the costs imposed by frivolous lawsuits. ${ }^{144}$

The liurdle erected by the pleading standards is raised even further by the discovery stay. ${ }^{145}$ The discovery stay prevents plaintiffs from using discovery to draft a viable complaint, a strategy frequently employed before the Reform Act. ${ }^{146}$ Discovery, lowever, may be the only source for the facts necessary to satisfy the pleading standards' requirement that the complaint plead facts giving rise to a strong inference that tlie defendant acted with scienter.

The facts relevant to the defendant's state of mind are likely to be in the sole possession of tlie defendant. ${ }^{148}$ The combination of the discovery stay and the pleading standards means tliat at least some meritorious actions will be thrown out on a motion to dismiss. Congress's efforts to give courts the tools to weed out frivolous

\footnotetext{
${ }^{141}$ See id. $\S 78 \mathrm{u}-4(\mathrm{~b})(1)$.

142 See id.

${ }^{143}$ See Fed. R. Civ. P. 8(a).

14 This shift aligns securities class actions more closely with derivative suit practice. Those suits are typically tried to a judge sitting in equity.
}

${ }^{145}$ See $\$ 78 \mathrm{u}-4(\mathrm{~b})(3)(B)$.

${ }^{146}$ H.R. Conf. Rep. No. 104-369, at 37 (1995) (discovery stay intended to discourage "fishing expedition" lawsuits).

${ }^{167}$ See Eth \& Dicke, supra note 22, at 105 ("direct evidence of scienter is usually nonexistent at the pre-discovery pleading stage").

14 See Alexander, supra note 95, at 513 ("Public investors have no way of learning through a pre-filing imvestigation whether insiders knew the adverse information before it was disclosed. The essence of the claim, after all, is that defendants kept their knowledge a secret."). 
claims necessarily undercuts some of the deterrent force of class actions. ${ }^{149}$ Deterrence is further undermined by the safe harbor that the Reform Act creates for forward-looking statements. The safe harbor immunizes such statements if they were not knowingly false when made, a departure from the ordinary standard of recklessness. ${ }^{150}$ Properly counseled, a company can have virtual blanket immunity for forward-looking statements. This immunity has the potential to reduce greatly the scope of corporate statements subject to hability and, consequently, increase greatly the potential for fraudulent misstatements.

The Reform Act erects real barriers to the filing of frivolous class actions. But at the same time, it impedes meritorious actions. ${ }^{152}$ Given the enormous danages exposure created by the fraud on the market presumption and the perverse imcentives created by the settlement process, the Reform Act may have been necessary to protect corporations from meritless actions. But that protection comes at a cost in the deterrence value of securities fraud class actions. ${ }^{153}$

${ }^{149}$ See Georgakopoulos, supra note 70, at 710-11 (noting correlation between stringent U.S. disclosure laws and lower cost of capital than other parts of the world); Grundfest, supra note 102, at 732 ("If there is insufficient litigation in the securities inarket fraud will be insufficiently deterred. Investors will then lose confidence in the market and demand a higher risk premium to coinpensate for the perceived loss of integrity. The result is a higher cost of capital and less capital formation than would occur at the socially optimal level of litigation."); Hillary A. Sale, Heightened Pleading and Discovery Stays: An Analysis of the Effect of the PSLRA's InternalInformation Standard on ' 33 and ' 34 Act Claims, 76 Wash. U. L.Q. 537, 579 (1998) (arguing that the Reform Act inay inake pleading impossible for some ineritorious cases).

${ }^{150}$ See 15 U.S.C. $\$ 77 z-2(c)(1)(B)$ (Supp. III 1997). A more extreine departure is the safe harbor's protection for even knowingly false statements if they were accoinpanied by sufficient cautionary language. See id. $\$ 77 \mathrm{z}-2(\mathrm{c})(1)(\mathrm{A})$.

${ }^{151}$ See 15 U.S.C. $\$ 77 z-2(c)(1)(A)$; see also John C. Coffee, Jr., The Future of the Private Securities Litigation Reform Act: Or, Why the Fat Lady Has Not Yet Sung, 51 Bus. Law. 975, 989 (1996) ("Probably the inost striking feature of the Reform Act's safe liarbor is the immumty it seems to give to a bald, knowing lie that is surrounded by 'meaningful cautionary stateinents."').

${ }^{152}$ See Walker et al., supra note 1, at 684-85 (concluding that the combination of pleading standards and discovery stay had made it more difficult to file securities class actions).

${ }^{153}$ The einpirical evidence suggests that this loss of deterrence is outweighed by savings froin fewer frivolous suits. See D. Katherine Spiess \& Paula A. Tkac, The Private Securities Litigation Reform Act of 1995: The Stock Market Casts Its Vote ..., 18 Managerial \& Decision Econ. 545, 546 (1997). D. Katherine Spiess and Paula 


\section{EXCHANGE INCENTIVES}

Exchanges serve corporations by providing liquidity for their securities. ${ }^{154}$ Liquidity greatly enhances the value of a corporation's securities, thereby reducing the corporation's cost of capital. ${ }^{155}$ As a result, corporations with a sufficient public float for their securities will strongly prefer to hist their securities for trading on an organized exchange. There are only three national exchanges-the New York Stock Exchange ("NYSE"), the American Stock Exchange ("AMEX"), and the National Association of Securities Dealers Automated Quotations/National Market System ("NASDAQ/ NMS") - and companies eligible to list their securities on one of these exchanges overwhelmingly opt for one of these over the regional exchanges. ${ }^{156}$ This demand for exchange services, combimed with the small number of exchanges, each holding a wide portfolio of histing corporations, enables the exchanges to serve a regulatory function. ${ }^{157}$ Under the proposal outlined below, ${ }^{158}$ compamies' ac-

Tkac found that early rumors of President Bill Clinton's veto were accompanied by significant negative abnormal returns, and that the House's override of the veto was accompanied by significant positive abnormal returns. See id. at 546 . Their findings have been confirmed. See Marilyn F. Johnson et al., Shareholder Wealth Effects of the Private Securities Litigation Reform Áct of 1995, at 18 (Feb. 1998) (unpublished manuscript, on file with the Virginia Law Review Association).

is See Macey \& Kanda, supra note 8, at 1009-10 ("[O]rganized exchanges provided listing companies with: (1) hquidity, (2) momitoring of exchange trading, (3) standard form, off-the-rack rules to reduce transaction costs, and (4) a signaling function that serves to inform investors that the issuing companies' stock is of high quality."); see also id. at 1041 (discussing exchanges and antifraud actions as alternative providers of credibility for issuer statements).

${ }^{155}$ See Norman S. Poser, Restructuring the Securities Markets: A Critical Look at the SEC's National Market System, 56 N.Y.U. L. Rev. 883, 886 (1981) ("For the sale of a new issue of securities to succeed, prospective purchasers must have a reasonable assurance of hquidity"). Restricted securities are subject to a substantial illiquidity discount. See Miller, supra note 66, at 148 (restricted securities typically sell for 20 $30 \%$ less than unrestricted equivalents).

${ }^{156}$ The regional exchanges are Boston, Cimcinnati, Chicago, Chicago Options Exchange, and Pacific. With the merger of the AMEX and NASDAQ, there are effectively now only two competitors anıong the national exchanges at this time. That merger, and the technology upgrades that should follow from it, mean, however, that the NASDAQ/AMEX and the NYSE are even more closely matched than before. The NYSE certainly perceives the NASDAQ/AMEX as a substantial competitive threat to which it has responded by considering unlisted trading in NASDAQ securities. See Greg Ip, Big Board Seeks a Way To Trade NASDAQ Stocks, Probably Electronically, Wall St. J., Feb. 26, 1999, at A1.

157 See Reinier H. Kraakman, Gatekeepers: The Anatomy of a Third-Party Enforcement Strategy, 2 J.L. Econ. \& Org. 53, 69-74 (1986) [hereinafter Kraakman, 
cess to secondary trading markets for their securities would be made contingent on their agreement to the enforcement regime administered by the exchanges. It would be very costly for a company eligible for one of the exchanges to forego listing to avoid enforcement. ${ }^{159}$ Exchanges are well placed to enforce an antifraud regime because of corporations' demand for liquid secondary trading markets.

A number of scholars have argued that securities exchanges have appropriate incentives to protect investors. ${ }^{160}$ As Paul Mahoney puts it, "Self-interested stock exchange members will produce rules that investors want for the same reasons that selfinterested bakers produce the kind of bread that consumers want."161 Craig Pirrong has shown, however, that exchanges may provide suboptimal investor protections due to interest group rentseeking within the exchange membership.

My purpose in this Part is to show that exchanges have strong incentives to combat fraud on the market and that those incentives are unlikely to be undermined by interest group pressures. I argue

Gatekeepers] (arguing that gatekeeping regimes are most effective with diversified client base and sinall number of gatekeepers).

1ss See infra Part IV.

159 Firms that delist froin an exchange suffer a significant loss in firm value. See Tyler Slumway, The Delisting Bias in CRSP Data, 52 J. Fin. 327, 333 (1997) (finding that delisting firms lost, on average, $14 \%$ of their value).

${ }^{160}$ See, e.g., Damiel R. Fischel, Organized Exchanges and the Regulation of Dual Class Common Stock, 54 U. Chi. L. Rev. 119, 152 (1987) [hereinafter Fiscliel, Organized Exchanges]; Daniel R. Fischel \& Sanford J. Grossman, Custouner Protection in Futures and Securities Markets, 4 J. Futures Markets 273, 274 (1984); Steven Huddart et al., Disclosure Requirements and Stock Exchange Listing Choice in an International Context, J. Acct. \& Econ. (forthcoming 1999); Paul G. Mahoney, The Exchange as Regulator, 83 Va. L. Rev. 1453, 1455 (1997) [lereinafter Mahoney, Exchange as Regulator].

${ }^{161}$ Mahoney, Excliange as Regulator, supra note 160, at 1459.

${ }^{162}$ See Steven C. Pirrong, A Positive Theory of Financial Exchange Organization with Normative Implications for Financial Market Regulation (1998) [lereinafter Pirrong, Positive Theory] (unpublished manuscript, on file with the Virgima Law Review Association); Steven C. Pirrong, The Self-Regulation of Commodity Exchanges: The Case of Market Manipulation, 38 J.L. \& Econ. 141, 143-44 (1995) [hereinafter Pirrong, Self-Regulation]; Steven C. Pirrong, The Organization of Financial Exchange Markets: Theory and Evidence 3 (1998) [heremafter Pirrong, Organization] (unpublished manuscript, on file with the Virgina Law Review Association); Steven C. Pirrong, The Efficient Scope of Private Transactions-Cost-Reducing Institutions: The Successes and Failures of Commodity Exchanges, 24 J. Legal Stud. 229, 254-55 (1995) [heremafter Pirrong, Efficient Scope]. 
that exchanges given antifraud enforcement authority are hikely to focus on deterrence, rather than on compensation, and that they will enforce antifraud provisions both vigorously and efficiently. Insofar as there are groups within the exchange membership that are disproportionately affected by fraud on the market, those groups are more likely to favor vigorous antifraud enforcement.

\section{A. Structure}

The exchanges have several advantages over class actions as momitoring devices. The institutional structure of the exchanges is well suited to antifraud enforcement. Each of the exchanges already has a preexisting enforcement division. These enforcement divisions, staffed by experienced securities hitigators (many of them SEC veterans), are currently devoted primarily to regulation of member broker-dealers. ${ }^{163}$ But these enforcement divisions can easily be expanded for antifraud efforts against listing corporations, so start-up costs would be minimal.

The exchanges also have a quasi-property interest in the stock prices quoted in their market. ${ }^{164}$ This interest effectively makes the exchanges residual claimants in the integrity of those stock prices. $^{165}$ The plaintiffs' attorneys who control shareholders' class

${ }^{163}$ See David P. Doherty et al., The Enforcement Role of the New York Stock Exchange, 85 Nw. L. Rev. 637, 638-39 (1991).

${ }_{164}$ See J. Harold Mulherin et al., Prices are Property: The Organization of Fimancial Exchanges from a Transaction Cost Perspective, 34 J.L. \& Econ. 591, 592 (1991) (arguing that exchanges hold property interests in securities prices).

${ }_{165}$ The exchanges' property interest in the stock prices is the product of the tendency for trading volume to concentrate in a security's primary listed market. See Macey \& Kanda, supra note 8, at 1018 ("[V]irtually all trades are consummated on the floor of the exchange on which a firm's shares are listed."); Miller, supra note 66, at 151 ("The order flow will tend to concentrate in a single market entirely on its own."); Poser, supra note 155, at 893 (regional exchanges account for very hittle of trading in NYSE and AMEX-listed shares). Free-riding in the forn of unlisted trading on other exchanges should not undermine the incentive created by this quasiproperty interest as long as the regime is self-financing. But the allocation of enforcement responsibilities between exchanges and alternative trading systems is an unsettled question. See Jonathan R. Macey \& Maureen O'Hara, Regulating Exchanges and Alternative Trading Systems: A Law and Economics Perspective, $28 \mathrm{~J}$. Legal Stud. 17, 24-26 (1999) (discussing enforcement difficulties created by entry of alternatives to traditional exchanges). Given the increasing importance of alternative trading systems, however, see id. at 46 , this allocation of responsibility would become 
actions have no incentive to maximize the deterrent effect of the suits that they bring; deterrence will generally be subordinated to the goal of attorneys' fees. Each of the exchanges, by contrast, would internalize the deterrence benefits of reducing trading fraud in its market. Exchanges that sanction fraud will not have to share their enhanced reputation for integrity with exchanges that do not take similar steps. Note also that the exchange will not only seek to protect the integrity of its prices; but will seek to do so at the least cost. ${ }^{166}$

\section{B. Broker-Dealer Incentives}

Exchanges make better trading fraud momitors than plaintiffs' attorneys because the exchanges' residual claimants are their member broker-dealers. Member broker-dealers "own" the exchange in the sense that only members can trade on the floor of the exchange and the broker-dealer's membership, or "seat," is a trans-

a more important question if antifraud authority over corporations were transferred to exchanges.

Companies cannot prevent unauthorized trading of their shares. See Ludlow Corp. v. SEC, 604 F.2d 704, 711 (D.C. Cir. 1979). Unlisted trading privileges are now automatic for any exchange. See Unlisted Trading Privileges Act of 1994, Pub. L. 103-389, 108 Stat. 4081 (1994), codified at 15 U.S.C. $\$ 781(f)(1)(A)(1994)$. For an argument that the issuer of the securities should be allowed to determine where those securities are traded, see Amihud \& Mendelson, supra note 73, at 1438 ("[I]ntermarket competition may result in a race to the bottom because the markets that establish strict regulations, while attracting companies to list, could lose traders who, for self-serving reasons, will trade elsewhere."). The SEC also does not allow exchanges to prevent their members from trading on other exchanges. See In the Matter of the Rules of the New York Stock Exchange, 10 S.E.C. 270, 292 (1941) (Multiple Trading Case). The SEC's efforts to encourage unlisted trading in NYSE stocks have not reduced bid/ask spreads in the securities affected. See Jeffry L. Davis \& Lois E. Lightfoot, Fragmentation Versus Consolidation of Securities Trading: Evidence froin the Operation of Rule 19c-3, 41 J.L. \& Econ. 209, 236 (1998) (finding that stocks subject to Rule 19c-3 - which allows NYSE meinbers to trade those stocks off the exchange-have greater spreads than stocks subject to Rule 390-whicl prohibits NYSE members from trading those stocks off the exchange). Despite the lack of evidence that Rule 19c-3 has any beneficial effects, the SEC is considering expanding its reach. See Greg Ip, SEC May Examine Big Board Rules Involving Off-Exchange Stock Trading, Wall St. J., Mar. 18, 1999, at C11 (citing speech by Commissioner Laura Unger).

${ }^{166}$ See John R. Lott, Jr., The Level of Optimal Fimes to Prevent Fraud When Reputations Exist and Penalty Clauses are Unenforceable, 17 Managerial \& Decision Econ. 363, 372 (1996) ("To the extent that markets internalize the costs of fraud or other crimes, markets will not ouly develop the right level of protection, but will also do it by the least costly means available."). 
ferable asset for which there is an active market. ${ }^{167}$ The value of the broker-dealers' seats will depend on the amount of trading on their exchanges. ${ }^{168}$ A little over one-third of broker-dealers' revenues come from trading commissions and their own trading. ${ }^{169}$ More trading obviously means more commissions, ${ }^{170}$ but more trading also means more hquid markets, which makes the brokerdealers' own trading more profitable. ${ }^{171}$ Lower liquidity raises execution costs for both informed and uninformed traders; higher execution costs will induce both groups to trade less frequently, assuming that the demand for trading is downward sloping. ${ }^{172}$ By reducing hquidity, trading fraud directly reduces broker-dealers' profits. The quest for trading volume will encourage the exchanges to enforce prohibitions against trading fraud. ${ }^{173}$

That quest for trading volume will be tempered, however, by the exchanges' need to compete for listings by companies. ${ }^{174}$ The

${ }^{167}$ See Poser, supra note 155 , at 888 . The exchanges themselves are organized as nonprofit organizations.

${ }^{168}$ See John O. Matthews, Struggle and Survival on Wall Street 98 (1994) ("[T]he value of NYSE seats capitalizes the expected profit of the NYSE brokerage business.").

${ }^{169}$ See NYSE, Fact Book for the Year 1998, at 78 (1999) [hereinafter NYSE Fact Book] (reporting that securities commissions made up $14.7 \%$ and trading and investments made up $15.9 \%$ of members' revenues in 1997).

${ }^{170}$ See Stout, supra note 87, at 642 ("Brokers are paid a commission on every stock transaction they execute, profiting from trades regardless of whether the trading investor profits. They therefore have financial incentives to encourage trading.").

${ }^{171}$ See Admati \& Pfleiderer, supra note 64, at 5 ("[I]nformed traders ... want to trade when the market is thick.").

172 See Stout, supra note 87, at 698 ("the available evidence suggests that the demand for stock trading is quite elastic").

${ }^{173}$ See Franklin R. Edwards, Listing of Foreign Securities on U.S. Exchanges, $5 \mathrm{~J}$. Applied Corp. Fin. 28, 35 (1993) ("If, because of inadequate disclosure, an einbarrassing episode were to occur with respect to the foreign securities traded on that exchange, customers might be driven away frow the exchange, and the exchange's trading volume reduced. The result could be lost revenues for the exchange for many years into the future."); Fischel, Organized Exchanges, supra note 160, at 124 ("The long-run profitability of an exchange is highly dependent on trading volume, which will fall if consumers doubt the exchange's imtegrity. It is clearly in the interest of exchanges to promote consumer confidence by policing abuses by members that cause investors to lose money-at least to the extent that policing is economically feasible.").

${ }^{174}$ See Fischel, Organized Exchanges, supra note 160, at 129-30 (arguing that exchanges will not compete for listings by adopting rules that diminish the value of companies already listed); cf. Stephen Choi, Regulating Investors not Issuers: A Market-Based Proposal 20 (1999) (unpublished manuscript, on file with the Virginia Law Review Association) ("[I]ndividual intermediaries competing for investors will undercut eacli other's attempts to imtroduce unnecessary protections."). 
dominant exchanges (the NYSE and NASDAQ/NMS) are closely matched in terms of trading performance. ${ }^{175}$ Efficiency of antifraud enforcement will give the exchanges another margin on which to compete for corporate histings.

Competition should improve antifraud enforcement even with only two primary competitors. ${ }^{176}$ Exchanges will take care in pursuing antifraud actions because bringing baseless actions will drive listings away. For this reason, exchanges will want to investigate thoroughly before bringing clains against a listing company. Theory would suggest that honest companies (i.e., those that have adopted effective procedures to discourage their managers from committing fraud) will want to signal the integrity of their officers and directors by precommitting the company and its agents to pay sanctions for fraud. This signal, if credible, would reduce the coinpanies' cost of capital. ${ }^{17}$ Exchanges that underinvest in fraud deterrence will lose lonest companies, leaving behind those companies most likely to commit trading fraud. Thus, accuracy in

${ }^{175}$ See Gary C. Sanger \& John J. McConnell, Stock Exchange Listings, Firm Value and Security Market Efficiency: The Impact of NASDAQ, 21 J. Fin. \& Quantitative Analysis 1, 22-23 (1986) (finding no statistically significant difference between listing on NASDAQ and NYSE).

${ }^{176}$ Computerized trading systems also promise to create additional competition for the NYSE and NASDAQ/AMEX, as they greatly reduce the costs of entry. See Macey \& O'Hara, supra note 165, at 36 ("The NYSE competes in important ways, not only with the NASD and the Frankfurt Stock Exchange, but also with Goldman Sachs and Instinet. And Instinet and POSIT compete with broker-dealers and organized stock exchanges as well as with other ATSs."). Note, however, that competition is not a prerequisite to exchange antifraud enforcement. An exchange with a monopoly will nonetheless offer the enforcement level demanded by consumers. See Fischel, Organized Exchanges, supra note 160, at $123 \mathrm{n} .11$ (argumg that competition is not necessary to induce exchanges to protect investors because "[in]onopolists, hike firms operating in competitive markets, have incentives to offer the level of quality that consumers demand"). Competition, however, may encourage experimentation in sanctions and procedures, leading to a more efficient enforcement regime. External competition also may be one means of reducing internal agency costs in enforcement.

in See Cox, supra note 43, at 747 ("Theorists suggest that narket signaling resolves this impasse; managers who truly do not wish to misbehave eimit a.message distinguishing their firm from firms whose managers misbehave."); Macey \& O'Hara, supra note 165 , at 38 ("Rational investors will discount the price they are willing to pay for shares by an amount sufficient to compensate themselves for expected future manipulation and insider trading. Thus, issuing firms have strong incentives to list on exchanges to the extent that such listings help issuers make credible commitments to investors that insider trading and manipulation will be eliminated."). 
enforcement will be rewarded as exchanges that prosecute only genuine fraud on the market will attract more listings.

That prediction becomes less clear if we relax the assumption that corporate managers act as faithful agents for their shareholders. If fraud on the market frequently reflects agency costs, it makes sense to also consider the role of agency costs in listing decisions. Compamies making histing decisions can be divided into two primary classes: small compamies considering initial public offermgs and deciding where to list their shares for the first time; and established compamies, already listed, that lave the option of switching exclianges. Agency costs are likely to be lower for startup companies because the corporate managers making the listing decision are likely to own a substantial portion of the company's equity. In addition, venture capitalists may hold large stakes in the company, and they are likely to have considerable influence on decisions made in connection with the public offering. If the managers list on an excliange that underenforces antifraud provisions, investors will discount the amount that they are willing to pay in the public offering to reflect the shares' lower value in the secondary tradimg markets. ${ }^{178}$ This discounting directly harms those managers and venture capitalists who are selling portions of their holdings in the public offering. Venture capitalists, in particular, will want to maximize their proceeds from the offering because they are unlikely to be involved with the firn going forward. Thus, they have no incentive to protect management's discretion to commit fraud. Because they internalize the costs of their decisions, we can conclude that managers and venture capitalists will have incentives to make efficient initial listing decisions. ${ }^{179}$

${ }^{178}$ The two major markets apparently are closely matched on other segments relevant to the listing decision: In a sample of IPOs for stocks meeting the NYSE's listing standards from 1991 to $1996,57 \%$ chose to list on the NYSE. See Shane A. Corwin \& Jeffrey H. Harris, The Initial Listing Decision of Firms that Go Public 1 (1998) (unpublished manuscript, on file with the Virginia Law Review Association). Thus, neither the NYSE nor the NASDAQ/NMS can be said to dominate the market for initial listings.

${ }^{179}$ See Amihud \& Mendelson, supra note 73, at 1442 ("The issuer of a security represents this collective interest [of security liolders] when considering the public offering of the security because the security's trading regime and liquidity will affect its value and thus will also affect the issuer's proceeds from the sale."); Arnold R. Cowan et al., Explaining the NYSE Listing Clroices of NASDAQ Firms, 21 Fim. Mgmt. 73, 83 (1992) (finding that firms are more likely to move from the NASDAQ 
Managers of seasoned companies already listed are less likely to internalize the costs of their decisions because they generally hold only a small portion of their company's equity. Moreover, they may favor the interests of long-term shareliolders over those of short-term shareholders (who value liquidity more highly). ${ }^{180}$ As a result, managers of estabhished companies may prefer exchanges with lax enforcement standards that would reduce the managers' exposure to fraud sanctions. On the other hand, insofar as insider trading is a motivation for fraud on the market, ${ }^{181}$ managers may prefer a market with more stringent enforcement. ${ }^{182}$ Greater enforcement leads to more liquidity, which allows imsider traders greater latitude to disguise their trades among the many trades done for liquidity, rather than informational reasons. ${ }^{183}$ Whether this preference will dominate managers' fear of sanctions for fraud is uncertaim. Thus, we cannot have the same degree of confidence in the listing decisions of managers of established compamies.

Such compamies are already listed, however, and under the proposed regime, managers will be forced to persuade their shareholders to switch listings because the switch would be subject to shareholder approval. ${ }^{184}$ In addition, changing listings requires SEC

to the NYSE if they have a greater bid/ask spread on the NASDAQ); R.B. Edelman \& H.K. Baker, Liquidity and Stock Exchange Listing, 25 Fin. Rev. 231, 247 (1990) (finding similar result for firms listing on AMEX); Theohary Grammatikos \& George Papaioannou, Market Reaction to NYSE Listings: Tests of the Marketability Gains Hypothesis, 9 J. Fin. Res. 215, 226 (1986) (finding that firms experienced greater abnormal stock returns upon announcing listing on the NYSE when they previously had larger bid/ask spreads).

${ }^{180}$ See Brian J. Bushee \& Christopher F. Noe, Unintended Consequences of Attracting Institutional Investors with Improved Disclosure 1-2 (1999) (unpublished manuscript, on file with the Virginia Law Review Association) (finding that, while firms imcrease their percentage of institutional holders when they improve disclosure policies, they also experience greater stock price volatility); cf. Nicholas L. Georgakopoulos, Why Should Disclosure Rules Subsidize Informed Traders? 16 Int'l Rev. L. \& Econ. 417, 427 (1996) (arguing that corporations may provide insufficient disclosure because long-term shareholders do not value liquidity).

${ }^{181}$ See supra notes 21-24 and accompanying text.

$182 \mathrm{Cf}$. Huddart et al, supra note 160 , at 28 (demonstrating that imsider traders prefer higher disclosure regimes).

${ }_{183}$ See id. at 14-15 (arguing that insider traders are attracted to higher disclosure exchanges).

${ }^{184}$ See infra Section IV.B.3. 
approval. ${ }^{185}$ The requirements of shareholder and agency approval substantially constrain managers' discretion to switch histings.

Institutional shareholders are likely to have an active voice if shareholders are asked to approve a histing switch. As large holders, institutional imvestors will have incentives to collect information on the effectiveness of exchanges' antifraud regimes. More importantly, they are the traders most likely to be affected adversely by information asymmetries created by fraud on the market. Because they trade more frequently than individual shareholders, institutions will suffer more harm from the greater bid/ask spreads caused by information asymmetries. ${ }^{187}$ Moreover, institutions trade in large blocks, and the presence of informed traders as a result of fraud on the market means that execution costs will be greater for those large trades. ${ }^{188}$ Traders may be unable to distinguish institutions trading for liquidity purposes and market professionals who have uncovered a pricing distortion caused by fraud on the market that they are trying to exploit. ${ }^{189}$ If traders are unable to distinguish verifiers from uninformed institutional investors, they will cliarge both groups a premium to reflect

${ }^{185}$ See infra note 278 and accompanying text.

${ }^{186}$ These obstacles to switching listings may mean that exchanges will focus their competitive effort on securing new listings. If so, they are likely to pursue more vigorous antifraud enforcement than they otherwise would. See Allen Ferrell, The Self-Regulation of Commodity Exchanges: The Case of Market Manipulation Reconsidered 24 (1998) (uupublished manuscript, on file with the Virginia Law Review Association) (arguing that competitive pressure in the market for new futures listings is likely to increase the level of investor protections for all listings).

${ }^{187}$ See Glosten \& Milgrom, supra note 67 at 72 (discussing imcreases im bid/ask spread caused by informed trading).

${ }^{188}$ See Lawrence R. Glosten, Insider Trading, Liquidity, and the Role of the Monopolist Specialist, 62 J. Bus. 211, 222 (1989) (suggesting that market inakers charge inore for large trades in the presence of informed traders); Paul Gompers \& Andrew Metrick, How are Large Institutions Different from Other Investors? Why do these Differences Matter? 1 (1998) (unpublished manuscript, on file with the Virginia Law Review Association) (finding that institutional investors have a strong preference for holding highly hquid stocks).

1* See Douglas W. Dianiond \& Robert E. Verrecchia, Disclosure, Liquidity and the Cost of Capital, 46 J. Fin. 1325, 1341 (1991) (disclosure benefits large traders most by reducing confusion of large hquidity traders with informed traders). But see Lawrence M. Benveniste et al., What's Special About the Specialist? 32 J. Fin. Econ. 61, 83-84 (1992) (arguing that specialists can reduce adverse selection probleins created by informed trading by inducing brokers to reveal reasons for trades). 
their expected trading losses. ${ }^{190}$ If institutional investors are more likely to be trading for liquidity reasons than informational reasons, this premium for trading will be a net loss to them. Given the difficulties of verification, it seems unlikely that institutions will be trading more consistently based on verification information than for simple liquidity reasons. ${ }^{191}$ And this will always be true for those institutions that have adopted a passive, index-based investment strategy. ${ }^{192}$ If this analysis is correct, institutional investors should favor histing on exchanges with strong antifraud enforcement, and should oppose any attempt by managers to switch to a more lax regime.

This analysis suggests that there may be discrete, well-organized groups within the exchange's membership that would strongly favor antifraud enforcement. ${ }^{193}$ One such group is the brokers who represent institutional clients by arranging block trades. ${ }^{194}$ Block trades are an important segment of the NYSE's business: They made up $48.7 \%$ of trading on the NYSE in $1998 .^{195}$ Block trades

${ }^{190}$ See Diamond \& Verrecchia, supra note 189, at 1346 ("If there is more asymmetry of information (less public disclosure), market makers quote less liquid prices to take account of the imcreased information revealed by a given order imbalance.").

${ }^{191}$ See infra notes $207-09$ and accompanying text. Specialists recognize that institutional investors pose less of a threat of trading on asymmetric information: While greater sliare looldings by insiders cause greater bid/ask spreads, no similar effect is found for greater imstitutional looldings. See Raymond Chiang \& P.C. Venkatesl, Insider Holdings and Perceptions of Information Asymmetry: A Note, $43 \mathrm{~J}$. Fin. 1041, 1045-47 (1988).

${ }^{192}$ While passive investors inay be able to improve their terms of trade relative to the quoted bid/ask spread by credibly communicating their lack of private information, communicating that information imposes transaction costs on the institution that it would prefer to avoid.

${ }^{193} \mathrm{Cf}$. Ronald W. Anderson, The Regulation of Futures Contract Innovations in the Umited States, 4 J. Futures Markets 297, 308 (1984) ("Futures exclianges are conspicuously political organizations where some members vie with one another for representation on the exchange governing bodies. Thus, it is possible for participants in the market wliose interests are significantly affected by the direction taken by an excliange to acquire membership and to compete with other members to try to proinote their interests.").

${ }^{194}$ Block trades are trades in excess of 10,000 shares. See Gregg A. Jarrell, Change at the Exchange: The Causes and Effects of Deregulation, 27 J.L. \& Econ. 273, 277 (1984). Such trades are carried out on behalf of institutional clients by brokers who specialize in this area of trading. See Poser, supra note 155, at 911 ("Large institutional orders... are generally negotiated by 'block positioning' firms, even though the orders inay subsequently be executed on an excliange."); see also Matthews, supra note 168, at 35 (describing operations of block positioning firms).

${ }^{195}$ See NYSE Fact Book, supra note 169, at 3. 
made by institutional investors for liquidity reasons are easily confused with informed trading (such as trading by verifiers), which means that institutional investors will face higher execution costs. Because greater transaction costs from fraud on the market will lead institutional investors to trade less frequently than they otherwise would, ${ }^{196}$ brokers who serve institutional investors should be proponents of vigorous antifraud enforcement. ${ }^{19}$

In addition, speciahists - the broker-dealers assigned to ensure an orderly market in listed coinpany shares ${ }^{198}$ - should strongly favor vigorous antifraud enforceinent by the exchange. Specialists are especially vulnerable to the loss of liquidity created by trading fraud. The possibility of information asymmetries is one component of the bid/ask spread. ${ }^{199}$ If greater informed trading causes specialists to increase their bid/ask spread, ${ }^{200}$ they can expect a lower volume of trading to go through their post. ${ }^{201}$ Alternatively, market makers may pay for the order flow of uninformed investors, which adds to their cost of doing business. ${ }^{22}$ Both of these phe-

${ }^{1 \%}$ See Allen B. Atkins \& Edward A. Dyl, Transactions Costs and Holding Periods for Common Stocks, 52 J. Fin. 309, 321 (1997) (demonstrating that greater bid/ask spreads lead to longer holding periods for securities); Kenneth Lehn, Globalization of Financial Markets: A Comment, 34 Carnegie-Rochester Conference Series on Public Pohcy 97, 98 (1991) (mutual funds facing higher transaction costs have lower turnover ratios).

${ }^{197}$ See Fischel, Organized Exchanges, supra note 160, at 125 ("Institutional investors, financial intermediaries, and wealthy individuals are responsible for a high (and increasing) percentage of trading on organized exchanges. The actions of these sophisticated market participants-im deciding what securities to purchase and on what terms-lead exchanges to adopt rules that benefit all investors.").

198 See Poser, supra note 155, at 889-90 (discussing the role of specialists).

${ }^{199}$ See Amihud \& Mendelson, supra note 73, at 1427 ("The bid-ask spread compensates for the costs of providing immediacy and, in particular, for the risks of inaintaining an mventory of the security and the possibility of trading against traders with superior information."); Hans R. Stoll, Inferring the Components of the Bid-Ask Spread: Theory and Empirical Estimates, 44 J. Fin. 115, 129 (1989) (providing empirical estimates of the effect of informed trading on the size of the bid-ask spread).

200 See Dechow et al., supra note 60, at 29 (reporting that bid/ask spreads imcrease after revelation of earnings mainipulation); Amihud \& Mendelson, supra note 73, at 1427 ("The lower the risk of trading against parties with superior information, the narrower the difference between the buying and selling price will be. In other words, the bid-ask spread will be smaller.").

${ }^{201}$ Specialists participated in $25.3 \%$ of NYSE transactions in 1998. See NYSE Fact Book, supra note 169 , at 18 .

202 Where market makers can sort informed from uninformed traders, they charge a lower price to the uninformed by paying the brokers for the right to make the trades. 
nomena suggest that specialists would also prefer a trading environment with fewer informed investors (i.e., fewer verifiers). ${ }^{203}$ Floor traders and inarket inakers would also prefer vigorous antifraud enforcement. Like the specialists, floor traders and market inakers specialize in providing liquidity and risk bearing, not in collecting information, ${ }^{204}$ so they will prefer enforcement policies that reduce information asymmetries.

There are unlikely to be well-organized groups within the exchange ineinbership wlio would oppose vigorous antifraud enforceinent. $^{205}$ Market analysts and imvestment advisors, who collect information on behalf of institutional and other substantial investors, are best positioned to function as verifiers of corporate statements. But analysts and advisors are unlikely to be able to identify

See Marshall E. Blume \& Michael A. Goldstein, Quotes, Order Flow, and Price Discovery, 52 J. Fin. 221, 226-27 (1997) (arguing that payment for order flow is for uninformed trades). On the question of payment for order flow, see Allen Ferrell, Protecting Small Investors: A Proposal for Curbing Broker Opportunism 40, 41 (1999) (unpublished manuscript, on file with the Virginia Law Review Association).

${ }^{203}$ Although few in number, see Spears Leeds, Equitrade To Merge Operations, Wall St. J., Mar. 3, 1999, at C2 (reporting number of specialist firms on the NYSE had declined from 54 in 1986 to 31 in 1999), specialists have long held influence over exchange policies out of proportion to their numbers. See Robert Sobel, N.Y.S.E.: A History of the New York Stock Exchange: 1935-1975, at 345 (1975) [hereinafter Sobel, N.Y.S.E.] (describing low "the specialists, as a group, emerged as the most powerful influence at the Exchange" during the 1930s); Macey \& Haddock, supra note 43, at 352 (describing specialists as a "powerful special interest groupD"). As of 1989, there were 432 specialists out of 1366 NYSE meinbers. See Benveniste et al., supra note 189 , at 65 . In 1936, there were 322 specialists, making up almost $25 \%$ of the NYSE's membership. See Robert Irving Warsliow, Understanding the New Stock Market 29 (1937). Insofar as antifraud enforcement facilitates the operation of the market for corporate control, see Fox, supra note 45, at 909 , broker-dealers involved in the mergers and acquisitions business will also favor enforcenent. See Matthews, supra note 168, at 30 (describing the mergers and acquisitions business as an "important source [ of profit and revenue for securities firms").

${ }^{204}$ See Pirrong, Positive Theory, supra note 162, at 32.

${ }^{205}$ To be sure, broker-dealer firms inay themselves commit fraud against their customers. Suclr frauds are likely to reflect agency costs within those firms, given the damage that a revealed fraud does to a broker-dealer's reputation. See Jonathan $\mathrm{R}$. Macey, Wall Street Versus Maim Street: How Ignorance, Hyperbole, and Fear Lead to Regulation, 65 U. Chi. L. Rev. 1487, 1502 (1998) ("An investunent bank that systematically tried to cheat its customers would lose its reputation, and, because capital is fungible, reputation is the only thing that enables investinent banks to distinguish themselves from their coinpetitors. Thus, although the liuge commission to be made on individual trades may give Wall Street salesinen an incentive to cheat their custoiners, the firms that these salesinen work for have strong imcentives to police against this kind of conduct."). 
themselves as verifiers in advance. Most verification is likely to result from accidentally uncovering evidence of fraud in the course of nornal market investigation. ${ }^{200^{\circ}}$ Analysts may be able to verify corporate statements in the same way that they attempt to collect private information: by consulting with customers, suppliers, or lower-level employees within the corporation. ${ }^{207}$ Private information collected in this way produces the trading profits that support the analyst's efforts. Efforts to verify, however, are unlikely to produce a consistent stream of inforination concerning fraud. Managers have strong incentives to suppress the fact that they are engaging in fraud on the market, making verification a difficult task. ${ }^{208}$ Any effort by the managers to suppress the fraud would be undermined by selective disclosure to analysts because trading by the analysts' customers would incorporate the truth into the market price for the company's stock. Thus, for every fraud that an analyst is able to uncover through verification, she is likely to miss several others. These undetected frauds create opportunities for the analyst's clients to be on the losing end of trades with clients of other analysts fortunate enough to be trading on verification imfornation. ${ }^{209}$ And the analysts' clients are nore likely to remember losses due to fraud than gains. Analysts are therefore unlikely to identify themselves ex ante as being winners rather than losers

${ }^{206}$ See, e.g., Dirks v. SEC, 463 U.S. 646 (1983) (former corporate officer disclosed massive fraud at corporation to market analyst after regulatory agencies failed to investigate); see also Georgakopoulos, supra note 70, at 695 ("Verifying information about securities, however, is prohibitively costly and practically impossible."). Market professionals who were able to uncover fraud on a consistent basis would likely find that other traders were unwilling to trade with them, insofar as they could be identified.

${ }^{207}$ Cf. Mahoney, Mandatory Disclosure, supra note 44, at 1098 ("Managers may be the only source, or the best source, of some types of information, but a company's einployees, suppliers, competitors, and creditors, among others, also generate valuable information about the company.").

${ }^{208}$ See Mark H. Lang \& Russell J. Lundholm, Corporate Disclosure Pohicy and Analyst Behavior, 71 Acct. Rev. 467, 467-68 (1996) (finding that the inost important sources of information relied upon by analysts are produced by manageinent).

${ }^{209}$ See Naveen Kanna et al., Insider Trading, Outside Search and Resource Allocation: Why Firms and Society May Disagree on Insider Trading Restrictions, 7 Rev. Fim. Stud. 575, 597 (1994) (noting that those analysts without verification information will be at a disadvantage to those with the information and will thus be discouraged from trading). 
from verification, thus making collective action to discourage antifraud enforcement by the exchange difficult. ${ }^{210}$

Opposition to antifraud enforcement is made even more unlikely by the fact that analysts who are risk averse to trading losses caused by fraud on the market will avoid covering securities that they consider to be vulnerable to fraud. Analysts, unlike investors, cannot diversify away this risk and amortize the cost over time: Their human capital is tied to their ability to beat the market through active trading. Empirical evidence supports this argument: Firms engaging in earnings manipulation experienced significant declines in analyst following around the time that the manipulation was revealed. ${ }^{211}$ By discouraging the creation of private inforniation (undisclosed fraud), the exchange enforcement regime reduces the incentive for traders to act as verifiers, thus making all traders better off. ${ }^{212}$ Thus, broker-dealers providimg analyst services are unlikely to present a substantial obstacle to antifraud enforcement.

\section{SEC Oversight}

The SEC also has a role in ensuring vigorous antifraud enforcement by the exchanges. Exchanges play the principal role in regulating the markets for tradimg securities, subject to SEC oversight. $^{213}$ Exchanges must register with the SEC, ${ }^{214}$ and their rules are subject to review and approval by the SEC. ${ }^{215}$ If the SEC is dissatisfied with the rules of an exchange, it has the power to amend those rules after notice and an opportumity for interested

${ }^{210}$ See A.C. Pritchard, Note, Government Promises and Due Process: An Economic Analysis of the "New Property," 77 Va. L. Rev. 1053, 1071-72 (1991) (arguing that collective action is unlikely when members of the affected group cannot identify themselves in advance).

${ }^{211}$ See Dechow et al., supra note 60, at 30. Firms that are more forthcoming with voluntary disclosure also tend to attract more analysts. See Lang \& Lundholm, supra note 208 , at 490.

${ }_{212}$ Cf. Douglas W. Diamond, Optimal Release of Information By Firms, 40 J. Fin. 1071,1073 (1985) (noting that the centralized release of information by a firm can make all traders better off).

${ }^{213}$ On the subject of SEC authority over the exchanges, see David A. Lipton, The SEC or the Exchanges: Who Should Do What and When? A Proposal to Allocate Regulatory Responsibilities for Securities Markets, 16 U.C. Davis L. Rev. 527, 53137 (1983).

${ }^{214}$ See 15 U.S.C. $\$ \$ 78 f(a), 78 f(b)(1994)$.

${ }^{215}$ See id. $\$ 78 \mathrm{~s}(\mathrm{~b})$. 
persons to be heard. ${ }^{216}$ Of particular importance here, the exchanges' enforcement of their rules is subject to SEC oversight. ${ }^{217}$ The exchanges are required to comply with the standards of due process in their enforcement proceedings. ${ }^{218}$ Decisions in those proceedings are appealable to the SEC and, ultimately, to the federal courts of appeals. ${ }^{219}$ Thus, if the antifraud regime proposed here were incorporated into the existing statutory structure governing exchanges, enforcement actions by the exchanges would be subject to scrutimy by both the SEC and the courts.

Subjecting the exchanges' antifraud regimes to SEC review would increase the assurance that exchanges were vigorously enforcing their antifraud rules. Increasing the stringency of enforcement in this way, however, comes at a potential cost. Exchanges compete vigorously for trading volume. ${ }^{220}$ Subjecting the antifraud regime to SEC oversight risks chilling competition among the exchanges. The SEC provides the exchanges with an effective mechanism for collusion. ${ }^{21}$ Like all rivals, the exchanges would

${ }^{216}$ See id. $\$ 78 \mathrm{~s}(\mathrm{c})$.

${ }^{217}$ See id. $\$ 78 \mathrm{~s}(\mathrm{e})$; see also Feins v. American Stock Exch., 81 F.3d 1215, 1217-19 (2d Cir. 1996) (noting that "[t]he Exchange Act establishes a scheine of regulation of the securities marketplace that combines self-regulation with oversight of direct regulation by government agencies (in this case, the SEC)"). The SEC can also bring actions to enforce an exchange's rules. See 15 U.S.C. $\$ 78 \mathrm{u}$ (d).

${ }^{218}$ See Feins, 81 F.3d at 1218; Doherty et al., supra note 163, at $643-47$ (discussing NYSE disciplinary procedings).

${ }^{219} 15$ U.S.C. $\$ \$ 78 \mathrm{~s}(\mathrm{~d})(2), 78 \mathrm{y}(\mathrm{a})(1)$.

${ }^{200}$ See Amihud \& Mendelson, supra note 73, at 1433-34 ("[I]ntermarket competition mduced many securities markets to improve their trading systems out of fear that trading would shift to other markets. Over the last two decades, competition drove markets around the world to imtroduce automation and modern trading procedures that facilitated investors' access to markets and reduced illiquidity costs.").

${ }^{221}$ See Miller, supra note 66, at 162 ("The danger is well known that pubhic regulators may, despite the best of intentions, use the power of the state to reinforce the existing tendencies toward cartelism im industries like the securities industry, even when the regulators have not actually been 'captured' by influential segments of the securities industry (or, $m$ the case of antitakeover rules, captured by incumbent corporate managers)."); Inability to Handle Orders Key to Trade Interruption, NASD Official Says, 31 Sec. Reg. \& L. Rep. (BNA) 241 (Feb. 19, 1999) (reporting comments by NASD President Richard G. Ketchum that the SEC policy of encouraging multiple self-regulating organizations ("SROs") would inake it "more difficult to maintain fair competition"). But see 15 U.S.C. $\$ \S 78 w(a)(2), 78 f(b)(8), 780-3(b)(9)$ (forbidding the SEC and exchanges from adopting any rule that imposes a burden on coinpetition not necessary or appropriate to further the purposes of the Exchange Act). 
prefer to establish their rules cooperatively. ${ }^{22}$ In order to avoid antitrust scrutiny for that cooperation, however, they need SEC validation of the cooperatively determined rules. ${ }^{223}$ Eliminating competition is a concern because imposing a uniform rule on all exchanges risks imposing an inappropriate or ineffective form of regulation on certain securities. ${ }^{224}$ In addition, the SEC may push for rules that are more stringent than would be cost justified.

This threat to competition is real given the limited number of rivals (two) in the inarket for exchange services. To be sure, poten-

22 As in most things economic, Adam Smith was the first to identify this tendency:

People of the same trade seldom meet together, even for merriment and diversion, but the conversation ends in a conspiracy against the public, or in some contrivance to raise prices. It is impossible indeed to prevent such ineetings, by any law which either could be executed, or would be consistent with liberty and justice. But though the law cannot hinder people of the same trade from soinetimes assembling together, it ought to do nothing to facilitate such assemblies; much less to render them necessary.

Adam Smith, The Wealth of Nations 128 (The Modern Library 1937) (1776). Note that in this passage, Smith not ouly identifies the imcentive of rivals for collusion, but also futility of government measures against them and the tendency of government to facilitate such collusion. Thus, in one short passage, Smith identifies not only the problem of cartelization, but also the arguments against the Slierman Act and the public clioice critique of government regulation's tendency to foster cartelization.

223 See Gordon v. NYSE, Inc., 422 U.S. 659, 667, 681-82 (1975); Poser, supra note 155 , at 897-98 ("[T]lue NYSE's ability to withstand an antitrust attack would depend on the SEC's oversight role."); see also Marianne K. Smythe, Government Supervised Self-Regulation in the Securities Industry and the Antitrust Laws: Suggestions for an Accomodation, 62 N.C. L. Rev. 475, 487-509 (1984) (discussing the relationship between securities imdustry self-regulation and the antitrust laws); Comment, Stock Exchange Listing Agreements as a Vehicle for Corporate Governance, 129 U. Pa. L. Rev. 1427, 1453-57 (1981) (discussing antitrust implications of stock exchange listing agreements).

${ }^{22}$ See Amihud \& Mendelson, supra note 73, at 1465 ("Regulators are incapable of knowing which trading regime is most beneficial for every security, and because they usually impose uniform rules that slould apply to all securities and all markets, the regulatory solutions may not be appropriate to all."); Miller, supra note 66, at 151 (arguing that enforced monopolization may discourage innovation).

${ }_{225}$ See Edwards, supra note 173, at 36 (finding that the SEC argues for disclosure rules more expensive than investors' willingness to pay); Miller, supra note 66 , at 163 (stating that excessive regulation ensures "that the regulator can never be blamed by his ultimate bosses in the legislature for lraving encouraged speculative excesses"). There is some empirical evidence supporting the argument that the SEC tends to overregulate: Extension of SEC disclosure requirements to the over-the-counter market in 1964 did nothing to reduce bid/ask spreads in that market. See Robert L. Hagerman \& Joanne P. Healy, The Impact of SEC-Required Disclosure and InsiderTrading Regulations on the Bid/Ask Spreads in the Over-the-Counter Market, $11 \mathrm{~J}$. Acct. \& Pub. Pol'y 233, 239-41 (1992). 
tial entrants also put competitive pressure on the NYSE and the NASDAQ/NMS. ${ }^{226}$ The regional exchanges and alternative trading systems could offer antifraud services, and there should be no obstacle to foreign exchanges offering such services as well, assuming that Congress creates the appropriate legislative authority. ${ }^{227}$ Fortunately for investors, cooperation among the exchanges may be more difficult here than in other enforcement contexts. The companies listed on the NYSE have significantly greater trading volumes, on average, than compamies histed on the NASDAQ/NMS or the AMEX. NYSE companies are therefore likely to have greater analyst followings, making fraud more difficult. Accordingly, a less stringent level of enforcement may be appropriate for NYSE companies relative to NASDAQ or AMEX companies. The tradeoffs between competition and strict SEC monitoring are difficult to weigh. Even if the SEC were not granted an explicit oversight role, the SEC would wield substantial influence with the exchanges in implementing an antifraud regime because of its authority over other aspects of exchange regulation. ${ }^{228}$ For this reason, the exchanges are unlikely to adopt an antifraud regime strongly opposed by the SEC.

${ }^{226}$ See Good-bye to all that: Will technology and competition kill traditional financial exchanges?, Economist, Jan. 30, 1999, at 67-68 (discussing threat that electronic trading systems pose for traditional exchanges).

${ }^{27}$ See Mahoney, Exchange as Regulator, supra note 160, at 1478 ("To a growing extent, the New York and London stock exchanges compete with one another for listings and trading volume in multinational corporations.... The need for governmental oversight of securities markets should be decreasing-not imcreasing-as nuarkets beconıe more imternational."). One might question, however, the likelihood of Congress encouraging foreign competitors to domestic exchanges by giving the foreign exchanges antifraud authority. One exception, given the North American Free Trade Agreement ("NAFTA"), might be the Toronto Stock Exchange. The Canadian markets are upgrading their operations to address the competitive threat posed by their American rivals. See Solange De Santis, Canada Exchanges Revamp Operations to Better Compete with U.S. Markets, Wall St. J., Mar. 16, 1999, at C15.

${ }_{223}$ See Lipton, supra note 213, at 549 ("[T]he Commission and the SRO do not always work through formal means of authority. Many regulatory problems are resolved through informal communications, joimt discussions, study, bargaining and political activities. Often these informal processes are appendages of the formal authority possessed by the SROs and the SEC."). 
The SEC also plays a useful role as a backup to exchange enforcement. ${ }^{299}$ Marcel Kahan argues that exchanges will want to suppress information about violations, rather than ferreting fraud out:

From the perspective of an exchange, the optimal image to convey to the public is that no violations of its rules occur, an image that is blunted by the discovery of violations, even if the violator is found and punished. Thus, to the extent that an exchange believes that, absent policing, certain violations are likely to remain undiscovered, its incentives to engage im such policing are substantially reduced. ${ }^{230}$

There are several responses to this criticism. In the first place, it is difficult to suppress the evidence of a drastic drop in a company's stock price or the resignation of an outside auditor. Even if companies and exchanges could easily suppress fraud from public disclosure, parallel SEC enforcement would undermine their ability to cover up corporate wrongdoing. Exchanges will want to develop a reputation with the SEC as vigorous enforcers of antifraud prohibitions because such a reputation would reduce the likelihood of an SEC investigation of its listed companies. If a company and its officers have been investigated and sanctioned by the exchange on which the company is listed, or if the exchange has dropped its investigation, the SEC would be less likely to bring a second enforcement action if the exchange has developed a reputation as a vigorous antifraud enforcer. Providing protection from SEC enforcement would further enhance the exchange's ability to attract histing companies.

The monitoring effect of SEC enforcement could be enhanced by mcreasing the civil penalties available to the SEC and by offering bounties to fraud on the market inforners. Such bounties are currently provided for information leading to insider trading prosecutions. ${ }^{231}$ Bounties would make it more difficult for company managers (or exchanges) to suppress information about fraud. Such bounties also would substitute for investigative efforts per-

${ }^{22}$ It would be a mistake to delegate all enforcement authority to the SEC. See infra notes 396-401 and accompanying text.

${ }_{230}$ Marcel Kahan, Some Problems with Stock Exchange-Based Securities Regulation, 83 Va. L. Rev. 1509, 1518 (1997).

${ }^{231}$ See 15 U.S.C. $\$ 78 u-1(e)(1994)$ (providing for the payment of bounties of up to $10 \%$ of the civil penalty imposed for persons providing information). 
formed by plaintiffs' attorneys under the class action regime. ${ }^{232}$ In suin, the threat of SEC enforcenent against fraudsters adds credibihty to the exchanges' promises of antifraud efforts because the exchanges' reputations as antifraud enforcers will be diminished if the SEC uncovers frauds that the exchanges missed or ignored. ${ }^{233}$

\section{Why Don't Exchanges Enforce Antifraud Sanctions Now?}

If exchanges have such strong incentives to police fraud, why have they not already done it? The easy answer to this question is that exchanges have hittle incentive to supplement the imprecise and costly deterrence provided by the class action regime. ${ }^{234}$ An exchange that sanctioned histed companies for fraud would expose those coinpames to class actions. A decision against a conipany would likely have res judicata effect in a subsequent class action, thus exposing the company to massive dannages. ${ }^{235}$ Coinpames cannot opt out of the class action regime under current law, so exchange enforcement would be a supplement rather than an alternative. $^{236}$ Moreover, the ouly sanction available to exchanges under current law is delisting, a draconian sanction that would punish shareholders without sanctioning wrongdoing managers. An effective enforcement regime requires a range of sanctions tailored to the offense. These sanctions would likely be unenforceable penalties if a u-

${ }^{222}$ See Weiss \& Beckerman, supra note 93, at 2061 (noting that modern technology put all lawyers in the same relatively advantageous position of monitoring corporate statements and price fluctuation).

${ }^{23}$ See Jennifer Arlen \& Reinier Kraakman, Controlling Corporate Misconduct: An Analysis of Corporate Liability Regines, 72 N.Y.U. L. Rev. 687, 713 n.62 (1997) (arguing that third-party momitoring can add credibility to enforcement promises).

${ }^{24}$ See Macey \& O'Hara, supra note 165, at 41 ("Even the antifraud provisions of the securities laws provide stiff competition for the exchanges as providers of reputational capital to listing firms. Investors are less willing to pay for assurances of quality when they know they can recover damages for misstatements or inaterial omissions by corporate manageinent.").

${ }^{235}$ See Parklane Hosiery Co. v. Shore, 439 U.S. 322, 332-33 (1979) (holding that defendant in private civil action was estopped from litigating factual issues decided in prior SEC enforceinent action).

${ }^{26}$ See 15 U.S.C. \& 78cc(a) (1994). 
thorized only by the exchange listing agreement; the exchanges would need statutory authorization to fine-tune their sanctions.

\section{E. Summary of Exchange Monitoring Advantages}

Exchanges have a substantial imterest in deterring fraud in secondary trading markets because fraud hurts liquidity, and liquidity losses hurt the profitability of the broker-dealers who make up the exchange membership. Exchange incentives are bolstered by the monitoring of institutional investors and the SEC, who will take an active interest in the exchanges' antifraud enforcement. ${ }^{238}$ Institutional investors should have the sophistication to evaluate the efficacy of the enforcement regime. Moreover, institutions are repeat customers. ${ }^{239}$ Consequently, institutions can bring market forces to bear in encouraging enforcenient-exchanges that fail to enforce will lose nrarket share. If an institution is dissatisfied with the antifraud efforts of an exchange, the imstitution can shift its future imvestments to companies listed on better regulated exchanges at a relatively low cost. Furthermore, if institutional monitoring were thought to be insufficient, nrarket forces could be supplemented by government regulation. SEC oversight would allow the SEC to

${ }^{237}$ Kahan, supra note 230 , at 1517 \& n.43; see also Choi, supra note 174 , at $27-28$ (discussing the need for expanded exchange enforcement authority under a selftailored regulatory regime).

${ }^{233}$ The exchange regime's rehance on momitoring by institutional investors gives it elements of a certification regime. See Stephen Choi, Market Lessons for Gatekeepers, 92 Nw. U. L. Rev. 916, 934-49 (1998) (discussing the market for certification services); Hayne E. Leland \& David H. Pyle, Informational Asymmetries, Financial Structure, and Financial Intermediation, 32 J. Fin. 371, 383-84 (1977) (discussing the role of financial internediaries in certifying corporate statements). Unlike typical certification regimes, however, there is no cost-effective way by which exchanges could screen ex ante public statements by companies to ensure their veracity; ex post enforcement is clearly the cheaper means of protecting the integrity of the market. See Arlen \& Carney, supra note 10, at 714 ("Screening for agents willing to commit fraud is costly and is unlikely to identify potential wrongdoers."). Despite the difficulties of ex ante screening, the NYSE is contemplating such procedures. See Greg Ip, Big Board May Do Background Checks on Listing Applicants' Senior Officials, Wall. St. J., Apr. 28, 1999, at B18 (discussing proposal to clieck for criminal convictions of listing company officials). The exchange's promise to sanction fraudulent misstatements ex post effectively certifies a conpany's stateinents to the market as nonfraudulent. The exchange's stringency of enforcement will determine the credibility of corporate statements so certified.

${ }^{29}$ See Darby \& Karni, supra note 63 , at 74-75 (concluding that repeat customers are less likely to be defrauded). 
sanction exchanges that do not vigorously enforce antifraud prohibitions. Government oversight, however, comes at a cost. That cost is the risk of collusion among the exchanges to limit regulatory competition, and bureaucratic overreaching by the SEC, both of whicli could lead to uniform, inflexible rules.

\section{THE EXCHANGE ALTERNATIVE}

\section{A. The Proposal}

My proposal would eliminate only class actions for fraud on the market, replacing them witl civil penalties and injunctive sanctions against the coinpany, its managers, and outside professionals. ${ }^{241} \mathrm{My}$ exchange-based antifraud proposal's nost radical departure froin the class action regime is that no damages are awarded to investors. Instead, sanctions imposed on coinpanies and their officers are retained by exchanges as compensation for their antifraud efforts. Accordingly, the proposal outlined here focuses purely on deterrence.

Such a proposal is not merely academic speculation, inconceivable in the real world. Congress considered eliminating fraud on the market class actions during the debates over the Reform Act. ${ }^{242}$ My proposal is niore politically palatable than this abandoned congressional initiative because it provides an alternative form of de-

${ }^{240}$ See Smythe, supra note 223, at 477 ("By placing the primary regulation of an enterprise in the hands of those who best understand the business, the regulations that are established by the self-regulatory organizations should be sensitive to the needs of the business and more carefully crafted than they would be if the government was the sole regulator.").

${ }_{241}$ Although it is beyond the scope of this Article, the logic of my proposal would also apply to class actions based solely on insider trading. Insider trading has the same effect on hquidity as verification, so exchanges have similar incentives to combat this abuse. See supra notes 64-73 and accompanying text. Moreover, plaintiffs' lawyers rarely can be bothered with pure insider trading class actions because the limited damages available would justify only minimal fees. As a result, such class actions are rare-most securities class actions allege misleading statements or omissions, although insider trading is frequently alleged as a motivation for the misstatements. See supra note 21 and accompanying text. Exchanges, being more interested in deterrence than financial recovery, might be more willing to bring imsider trading enforcement actions.

${ }^{242}$ See Georgakopoulos, supra note 70, at $673 \mathrm{n} .6$ (discussing provision requiring actual reliance in securities fraud suits that was part of proposed "Common Sense Legal Reforms Act of 1995"). 
terrence. ${ }^{243}$ Moreover, my proposal is limited in scope, removing the threat of class action lawsuits only for those companies that list on an exchange with an antifraud enforcentent regime. This limited repeal of the class action mechanisnt would give companies a powerful mcentive to list on an exchange with an antifraud regime. ${ }^{244}$

In order to foster competition for listings, only those exchanges where the corporation has agreed to be listed sliould be allowed to enforce trading fraud sanctions. The antifraud regime would become part of each corporation's listing agreenient with the exchange-the company would agree to subject itself (and its officers, directors, and outside professionals) to the enforcement authority of the exchanges. ${ }^{24}$ Exchanges that provided unlisted trading would provide important moritoring, as they wonld be certain to report to the SEC if they believed that the listing exchange was turning a blind eye to fraud. The options markets, in particular, are hikely to be sensitive to the liquidity costs created by fraud on the inarket's information asymmetries. ${ }^{24}$

In theory, exchanges could provide two tiers of listing-regular and antifraud-with only the latter subject to antifraud enforcement. There are reasons to doubt, however, that a two-tier system would develop. First, exchanges might be reluctant to dilute the reputational effects of their antifraud regimes by leaving some listed firms outside its reach. Second, the cost of the current class action regime suggests that the demand for non-antifraud histings

${ }^{243}$ Eliminating these class actions would require legislation, as the Exchange Act includes an antiwaiver provision preventing investors from giving up their legal remedies under the Act. Congress has demonstrated its skepticisin of class actions in the Uniform Standards Act, which eliminates state fraud class actions while preserving individual actions. See supra note 5 and accompanying text.

${ }^{244}$ There is no necessary requirement that an alternative enforcement regime be administered by an exchange. Other entities might also be able to provide antifraud enforcement services. See Choi, supra note 174, at 26 (arguing that a broad array of institutions could provide investor protection services). I focus on exchanges because of the comparative advantage that they hold in antifraud enforcement. See supra notes 154-77 and accompanying text. Thanks to Einer Elhauge for this point.

${ }_{245}$ See Harding v. American Stock Exch., 527 F.2d 1366, 1367 (5th Cir. 1976) ("One of the prerequisites to listing on AMEX is the execution of an agreement in which a registrant agrees to abide by the rules and regulations of AMEX.").

${ }_{246}$ See Suzanne McGee, Where Have the Insider Traders Gone? Options Markets Are Their New Home, Wall St. J., Apr. 23, 1997, at C1 (reporting concerns of options traders about vulnerability to insider trading). Options are attractive to insider traders due to the greater leverage they provide relative to shares. 
would be small because those companies would remain subject to class actions. Some firms, not particularly vulnerable to class actions because of their smaller trading volume, might initially be tempted to opt for a non-antifraud histing. ${ }^{24}$ Once deprived of their natural prey, however, plaintiffs' attorneys are likely to hunt more widely for potential defendant-corporations, so smaller firms may become vulnerable to the class action, and thus, have an incentive to migrate to the antifraud listing. This result would probably benefit investor protection because more thinly traded stocks are also more susceptible to mampulation. Indeed, given the vulnerability of smaller firms to mampulation, it may be preferable to require exchanges to enforce antifraud prohibitions agamst all listed compamies. ${ }^{248}$ Even if not inandated by law, encouraging smaller firms to subject themselves to antifraud enforcement by the exchanges would plug a liole in current enforcement efforts.

A number of features would be left unchanged under my pro* posed exchange-based antifraud regime. Actions in which the $\mathrm{m}$ vestor had purchased securities directly from the company or its underwriter would be left unaffected. ${ }^{249}$ In these cases, the company (rather than the managers) lias received a direct benefit from the misstatements and the benefit must be disgorged to provide adequate deterrence. More importantly, the investor must be compensated in order to discourage precaution costs agamst such fraud. Diversification can convert the risk of wealth transfers froin fraud into a fixed cost im these cases, but imvestors will nonetheless discount the amount that they are willing to pay for shares to reflect that fixed cost. Alternatively, uncompensated investors may defect to markets not infected by fraud (e.g., Treasury bills), which

${ }^{277}$ See Grundfest, supra note 102, at 734 n.46 (" $[\mathrm{F}]$ or almost two-thirds of the issuers listed on NASDAQ, a $10 \%$ decline in stock price might not be sufficient to trigger litigation even if plaintiffs' counsel is firmly convinced that there has been a fraud because there is simply not enougl at stake to make litigation worthwhile.").

${ }^{248}$ See Suzanne Manning \& Phyllis Diainond, Internet, Munis, Microcap Fraud Head List of New Chief Richard Walker, 30 Sec. Reg. \& L. Rep. (BNA) 942 (June 19,1998 ) (reporting that new head of SEC enforcement considers fraud in the microcap market to be a top enforcement priority); Elizabeth MacDonald \& Joann S. Lublin, SEC May Put Small Firms in Audit Plan, Wall St. J., Mar. 25, 1999, at A2 (reporting results of study finding that "most financial-statement fraud is committed by companies with tiny inarket capitalizations and less than $\$ 100$ million in assets and revenue").

${ }^{249}$ See 15 U.S.C. $\$ \S 77 k, 771$ (1994). 
could affect resource allocation. Compensation is essential to ensure investor participation in the new issues market.

In addition, individual actions under the Exchange Act could still be maintained by plaintiffs who could prove actual reliance on a misstatement, with or without privity. Allowing rehance actions would minimize precaution costs by investors who actively collect market information while excluding actions by verifiers who do not rely on corporate statements. ${ }^{250}$ Individuals who actively collect market information and have relied on statements made by corporations need to be coinpensated when they are misled in order to discourage them from becoming verifiers. Discouraging the social waste of verification and its attendant liquidity costs should be the central goal of any antifraud regime for secondary trading markets. ${ }^{251}$

Also unaffected would be SEC enforcement actions. As discussed above, the threat of SEC enforcement would encourage the exchanges to vigorously enforce antifraud prohibitions. ${ }^{252}$ In addition, hard core fraud probably requires criminal sanctions for judgment-proof individuals, and the SEC plays a vital role in brimging such conduct to the attention of U.S. Attorneys. SEC enforcement is essential for those companies that have not listed their stock on any of the exchanges, putting thein beyond the reach of exchange enforceinent. Such companies are likely to have a smaller public float and trading volume and are thus especially vulnerable to stock price manipulation. ${ }^{253}$ Antifraud enforcement may liave some aspects of a public good, and government provision of such services may be inportant im maintaining adequate enforceinent levels. Thus, SEC enforcenrent would remain an integral part of the overall antifraud regime.

${ }^{250}$ Individual actions could also be brought against broker-dealers who mislead their customers. These actions could be made more effective by relaxing the typicality standards for class actions, which would ordinarily preclude class action certification if investors had to establish individualized reliance.

${ }_{251}$ See Georgakopoulos, supra note 180 , at 429 ("[S]ecurities regulation has a specific ultimate goal: the liquidity of securities markets.").

252 See supra notes $229-30$ and accompanying text.

${ }^{253}$ Fraud in the "micro-cap" market is an important priority for government enforceinent. See Manning \& Diamond, supra note 248. 


\section{B. Sanctions}

\section{Monetary Sanctions}

A principal benefit of the proposed regime is that exchanges would be able to experiment with different sanctions for trading fraud. In particular, monetary sanctions for fraud on the market would tikely be significantly reduced from the current damages measure. As discussed earlier, the net social costs of fraud on the market are much lower than the measure of damages used in class actions. ${ }^{24}$ This inflated measure of damages pushes compamies toward settlement. Reducing sanctions would level the playing field and encourage compamies with strong defenses to litigate to a decision on the merits.

Reduced monetary sanctions would not jeopardize deterrence. The primary costs of fraud on the market are reduced liquidity im the stock markets and diminished momitoring of corporate managers' performance..$^{255}$ Remedies other than the securities class action exist for the latter problem. Insofar as manipulating the company's stock price allows managers to extract unearned compensation or distorts shareholder voting, state corporate law provides a remedy. Alternative remedies also address the problem of inappropriate allocation of capital. Where the corporation has misled a lender or imvestors in an offering about its future prospects, the lender and mvestors will continue to have legal remedies if they have relied on the corporation's misstatements. In a public offering, investors would not be required to demonstrate reliance under Section 11 of the Securities Act. ${ }^{256}$ These alternative sanctions must be considered in determining the optimal sanction for the exchanges' antifraud regimes, which are more properly focused on liquidity costs.

By targeting enforcement at the corporate managers responsible for the misstatements, exchanges could greatly reduce monetary sanctions while still achieving deterrence. Exchanges, unlike plaintiffs' attorneys, are interested in deterrence, not just monetary recovery. Consequently, exchanges should be concerned not only with the amount of damages, but also with who pays. An exchange will achieve greater deterrence for a given sanction by directly im-

${ }^{24}$ See supra notes 52-55 and accompanying text.

${ }_{25 s}$ See supra Section I.B.

${ }^{256}$ See 15 U.S.C. \& 77k (1994). 
posing it on the party responsible for the fraud. ${ }^{257}$ Plaintiffs' attorneys, by contrast, readily trade off deterrence to secure a larger recovery, and therefore do not object to the managers' attempts to shift liability to the corporation. As discussed above, in many, perhaps inost, trading fraud cases, the officer or director responsible for the misstatement made the stateinent for his own benefit, not the corporation's. ${ }^{258}$ In these circumstances, sanctioning the corporation-as the class action settlement does-penalizes the shareholders of the corporation for conduct that in no way benefited them. Placing enforcement authority in the hands of exchanges would make it more likely that wrongdoing managers are sanctioned for trading fraud.

The social costs of fraud on the market are difficult to quantify. ${ }^{259}$ Instead of a harm-based sanction, exchanges would likely adopt a disgorgement sanction, inultiplied to reflect the probability of nondetection. ${ }^{260}$ Managers who distorted stock prices in order to manipulate a stock price-based compensation scheme would be forced to disgorge the excess gains; msider traders would be forced to give up their profits. ${ }^{261}$

The multiphier applied to these sanctions, however, should not be excessive. ${ }^{262}$ Excessive sanctions may cause managers to with-

${ }^{257}$ See Michael S. Raab, Detecting and Preventing Financial Statement Fraud: The Roles of the Reporting Company and the Independent Auditor, 5 Yale L. \& Pol'y Rev. 514, 523 (1987) (reporting results of survey finding that to reduce the rate of corporate fraud $83 \%$ of "financial executives, corporate secretaries, internal auditors, lawyers, and public accountants ... recommended that more severe penalties be assessed against the perpetrators of financial statement fraud').

258 See supra notes 10-21 and accompanying text.

${ }^{259}$ See supra Sections I.B.1-2.

${ }^{260}$ See Langevoort, Capping Dainages, supra note 52, at 658 ("The best heuristic substitute for net social harm is a benefit-based ineasure, taking into account the significant probability of nondetection."). It is interesting to note in this regard that a survey of Justice Department imvestigators and prosecutors found that this group believed that the probability of fraud being detected and punished was, on average, $38 \%$. See Lott, supra note 166 , at $375 \&$ tbl.1.

${ }^{261}$ See Alexander, supra note 88, at 1515 (advocating "the disgorgeinent of any benefits defendants received froin the violation, such as proceeds from any transactions they engaged in during the period of nondisclosure, increases in the value of stock options, or other compensation tied to the misleading statements or to the stock price during the period of nondisclosure").

${ }^{262}$ In order to apply a multipher legislation would be required to ensure that the exchanges could impose punitive sanctions. See Kahan, supra note 230, at $1517 \mathrm{n.43}$ ("Without some federal law delegating regulatory power to stock exchanges, the duty 
hold information from the markets in order to avoid liability, which would undermine the purposes of the antifraud regime. ${ }^{263}$ Excessive sanctions could have deleterious effects beyond diminished disclosure. Managers are likely to be risk averse because of the high percentage of their personal wealth that they have tied up in their relationship with the corporation. ${ }^{264}$ Given the risk aversion of managers, sanctions can be set lower than the social costs of fraud on the market and still deter. ${ }^{265}$ In addition, managers facing draconian sanctions would require additional compensation from the corporation for bearing that risk, and shareholders would ultinuately bear that cost. ${ }^{266}$ The risk imposed by the fraud on the market class action is tolerable only because the combination of $\mathrm{D} \& \mathrm{O}$ insurance and universal settlement effectively immunizes the managers from liability. If managers had a real risk of paying a judgment, they would demand enormous risk premiums. ${ }^{267}$ Thus, overdeterrence is a real risk.

of listed companies to comply with stock exchange rules would presumably be based on contract. If a company violates these rules, the exchange may delist the company's stock or get damages for breach of contract, but may face difficulty in assessing supra-compensatory fines.").

${ }_{263}$ See Langevoort, Capping Damages, supra note 52, at 652 ("Managers will tend either to disclose too inuch (which is at least costly, often contrary to the company's business interests, and perhaps misleading by virtue of the dilution effect) or to say little or nothing at all when they want to keep secrets for fear of the uncertain consequences of addressing a subject in the first place given the dimly illuminated nargins of the lialf-truth doctrine and the duty to update.").

${ }^{264}$ See Reinier H. Kraakman, Corporate Liability Strategies and the Costs of Legal Controls, 93 Yale L.J. 857, 879 (1984) [hereinafter Kraakman, Liability Strategies] ("Hired managers have made an undiversified investment of their managerial assets in the firm and must charge dearly for their personal risk-bearing services.").

${ }^{265}$ See Richard Craswell, Damage Multiphers in Market Relationships, 25 J. Legal Stud. 463, 465 (1996) ("If offenders are risk-averse, the deterrent effect of any given fine will exceed that fine's expected value; if offenders are risk-preferring, the deterrent effect will be less. To achieve optimal deterrence, then, the fine will have to be adjusted upward or downward, until its discounted disutility equals the social harm caused by the offense.").

${ }^{266}$ See id. at 468 ("Even when merely inonetary sanctions are used, if defendants are risk-averse, then the threat of having to pay such a fine will increase defendants' risk-bearing costs.").

${ }^{267}$ See Holderness, supra note 123, at 118 ("[L]iability insurance shifts risks and thus reduces the cost to the firm of compensating risk-averse directors and officers."); Kraakman, Liability Strategies, supra note 264, at 865 ("[U]umsured managers will of course demand a very large risk premium if they are simiply paid outright for enduring even a small probability of catastrophic personal liability."). 
In addition to the financial toll, sanctions imposed by an exchange are likely to exact significant reputational losses on either a manager or a corporation. The reputational loss from an exchange enforcement action likely exceeds that produced by a class action because of the greater credibility of exchange enforcement. An enforcement action brought by the NYSE or the NASD caimot be explained away as a frivolous attempt to extort attorneys' fees. Exchanges would need to take care not to reproduce the perverse incentives created by the class action by setting sanctions too high.

Exchanges will also be able to take steps to discourage managers from shifting liability to the corporation. Given their interest in deterrence, exchanges are more likely to adjudicate allegations of fraud, leading to findings of fraudulent imtent. Alternatively, exchanges could require defendants to agree to settlements that imclude stipulations of wrongful imtent. Either adjudication or stipulation would preclude insurance coverage and indemnification. $^{268}$ While settlements including such stipulations would be more difficult to secure, they would provide greater deterrence because they prevent liability shifting by wrongdoing corporate managers. Thus, if properly targeted, smaller sanctions could have a greater deterrent effect. ${ }^{269}$

If the company actually benefited from the fraud, it could be forced to disgorge its benefits as well. Disgorgement could be supplemented by civil penalties for cases in which the benefit to the defendant was hard to quantify but the fraud was clear. ${ }^{270}$ Determiming the appropriate range for sanctions is necessarily speculative once we have eliminated the traditional measure of damages in fraud cases as inappropriate. Because the social costs of fraud on the market (e.g., loss of liquidity, reduced managerial accountabil-

${ }^{26 s}$ See Monteleone \& Conca, supra note 123, at 599 (excerpting D\&O policy provision excluding losses arising froin "fines or penalties imposed by law"); id. at 600 (excerpting provision excluding coverage for "remuneration paid in fact [to officers or directors] if payment of such remuneration shall be held by the Courts to be in violation of law"); id. at 601 (excerpting provision excluding coverage for "deliberately dishonest or fraudulent act[s]").

${ }^{269}$ See Alexander, supra note 88, at 1512 ("A relatively small penalty to be paid personally (and by law made uninsurable and not indemnifiable) could have a larger deterrent effect on individuals than a much larger coinpensatory judgment to be paid by the corporation and its insurers.").

${ }_{270}$ See Langevoort, Capping Damages, supra note 52, at 657-61 (discussing the need for penalties in cases where the benefit to the defendant is liard to quantify). 
ity) are difficult to quantify, setting the appropriate sanction is correspondingly difficult. Based on average settlements under the class-action regime, Janet Cooper Alexander suggests that "[p]enalties for issuers might be set in the range of five to fifteen million dollars, based on the size of the issuer, and might be doubled on a finding of intentional fraud. Penalties for individuals might be in the $\$ 100,000$ to $\$ 300,000$ range." 271 Donald Langevoort suggests a similar range. ${ }^{272}$ While these suggestions are somewhat arbitrary, I am unable to offer here a measure with a stronger empirical basis. One of the advantages of the exchange-based enforceinent regime is that it deals with this information deficit by allowing for experiinentation (checked by market forces) in determining the optimal sanction. Markets are powerful information-producing mechanisms; ${ }^{273}$ competitive pressures will encourage the exchanges to set sanctions at the appropriate level. Departing from the compensatory ineasure of damages, which threatened massive sanctions against managers but was virtually never imposed, to a smaller sanction with a much higher probability of imposition, will produce greater deterrence. ${ }^{274}$

\section{Injunctive Relief}

Monetary sanctions could be bolstered by injunctive relief. Exchanges could seek the dismissal or suspension of the manager responsible for the fraud, a remedy currently used only by the SEC. Putting such a reinedy in the hands of plaintiffs' attorneys would be troubling because of the risk that they would use such a penalty as leverage in negotiating settleinents. ${ }^{275}$ Exchanges would be inore likely to use such a penalty to enhance deterrence. If maintaining the perquisites of office is an important incentive to commit fraud

${ }^{271}$ See Alexander, supra note 88, at 1515.

272 See Langevoort, Capping Damages, supra note 52, at 661 ("Admitting to some arbitrariness, my sense is that for a large Fortune 500-type coinpany, an appropriate level of deterrence for deliberate, serious management frauds could be achieved with a maximum direct exposure in the range of $\$ 10$ million.").

${ }^{273}$ See F.A. Hayek, The Use of Knowledge in Society, 35 Am. Econ. Rev. 519 (1945).

${ }^{274}$ See James Q. Wilson \& Richard J. Herrnstein, Crime and Human Nature 397401 (1985) (argumg that individuals are more likely to be deterred by higll probability/low sanction than by equivalent low probability/higl sanction).

${ }_{275}$ See Langevoort, Capping Damages, supra note 52, at 661 ("Placing [the threat of removal] in the lands of an opportunistic plamtiffs' lawyer may be offering too much leverage for unduly high dollar settlements of low-merit cases."). 
on the market, depriving the wrongdoer of that office is a particularly appropriate penalty, especially in cases where the benefit to the defendant is hard to quantify. ${ }^{276}$ Narrowly tailored penaltiesinposed directly on wrongdoing managers-will allow the exchanges to achieve deterrence at a lower cost than the class action regime.

\section{Shareholder Approval for Delisting}

In order to impose sanctions directly on managers and directors, the exchanges would need rules requiring shareholder approval for coinpanies seeking: to switch their listing to another exchange. Shareholder approval would prevent company managers from threatening to dehist froin an exchange in order to coerce a cheap settlement. The NYSE recently diluted its delisting provision because it no longer served any investor protection purpose and was putting that exchange at a conipetitive disadvantage. Corporations were reluctant to list on the NYSE because its stringent delistmg provision effectively precluded switching listings to competitor exclianges. ${ }^{277}$ Currently, only the NYSE requires shareholder approval for delisting. ${ }^{278}$ Exchange delisting rules requiring slareliolder approval-albeit not as restrictive as the NYSE's former rulewould be needed under an exchange-based antifraud regime. The Exchange Act provides an important backstop here: Decisions by an issuer to delist its securities are subject to SEC approval. ${ }^{279}$

\section{Vicarious Liability}

Separating the antifraud regime from the goal of compensation allows for a rethinking of vicarious liability against the corporation. Under the class action regime, vicarious liability allows inanagers to shift sanctions from themselves to the corporation, thus undermining deterrence. Without the need for compensation, the corpo-

${ }^{276}$ See Raab, supra note 257 , at 524 ("barring wrongdoers from corporate office can provide greater levels of deterrence than fines alone"); cf. Fischel, Modern Finance Theory, supra note 57 , at 16 ("[I]n many securities fraud cases the gains to defendants will be very difficult, if not impossible, to measure.").

27 See Macey \& Haddock, supra note 43, at 350 (criticizing the NYSE delisting rule as making it "extraordinarily difficult for a listed company to delist voluntarily").

${ }^{278}$ See NYSE Rule 500, NYSE Guide (CCH) 92500 , at 4231 (Oct. 1993).

279 See 15 U.S.C. \& 781(d) (1994). 
ration's "deep pocket" is no longer needed to assure a viable funding source for a judgment. Vicarious hability nonetheless may play a more positive role under an exchange-based regime that focuses on deterrence, especially in the excessive optimism cases described by Langevoort, ${ }^{230}$ where no individual may have the necessary scienter for fraud liability. Vicarious hability could encourage directors to insist on procedures designed to enhance the integrity of information flows within the corporation. ${ }^{28}$

Vicarious hability may also play a role in splitting the interests of the corporation from the interests of its managers. The corporation's vicarious hability for the misstatements of its managers could be reduced if the corporation took steps to control fraud. Reducing liability when the corporation had an established pohicy for controlling the accuracy of its public statements would encourage compamies to adopt disclosure pohicies under the supervision of their general counsels, subject to review by the audit committee of outside directors. ${ }^{282}$

Further reducing liability when corporations reported fraud to the exchanges' enforcement arms would help bring greater scrutimy to those misstatements. ${ }^{283}$ Firms are unlikely to volunteer information under the class action regime because it mcreases their hability

${ }^{250}$ See Langevoort, Organized Illusions, supra note 25, at 119-26; supra notes 25-34 and accompanying text.

${ }^{281}$ See Langevoort, Organized Illusions, supra note 25, at 128 (noting that vicarious liability with knowledge imputed to the corporation means that "senior executives cannot prevent corporate hability simply by beliaving honestly as a group, but imstead must implement the best available imternal information-control devices to nuanage the liability risk").

222 See generally Harvey L. Pitt \& Karl A. Groskaufmanis, Minimizing Corporate Civil and Criminal Liability: A Second Look at Corporate Codes of Conduct, $78 \mathrm{Geo}$. L.J. 1559 (1990) (discussing corporate efforts to reduce hability exposure through corporate codes of conduct); see also Raab, supra note 257, at 519-24 (discussing conipany procedures for ensuring the integrity of financial statements); Rachel Witmer, Accountants: Audit Committee Reliance on Internal Auditor Will Aid Fraud Detection, Panelist Says, 30 Sec. Reg. \& L. Rep. (BNA) 1204 (Aug. 7, 1998) (discussing steps that audit committees can take to discourage fraud).

$2 \times$ The exchanges' enforcement arms currently take a broker-dealer's cooperation into account in determining sanctions levels. See NASD's New Sanctions Guidelines Expand Range of Sanctions For Failure to Supervise, 30 Sec. Reg. \& L. Rep. (BNA) 823 (May 29, 1998) (reporting comment by NASD Executive Vice President for Enforcement that "[y]ou will receive credit, and I think significant credit, for cooperative behavior") (internal quotation marks omitted). 
exposure. ${ }^{284}$ The compensatory paradigm does not allow for damages reductions to encourage momitoring and reporting, ${ }^{285}$ but an exchange-based regime-focused on deterrence-could.

Giving the corporation an opportunity to reduce its liability exposure should encourage the outside directors to bring inore fraud to light, and consequently, produce greater deterrence of managerial misconduct. ${ }^{286}$ Outside directors are unlikely to be implicated in the frauds because little of their wealth is tied up in their relationship with the corporation; they are not likely to be involved in "last period" probleins. For these directors, the more salient imterests are their reputations, which would be greatly tarnished by entanglement in a fraud. ${ }^{287}$ As parties unlikely to be involved in the fraud, they are better placed to protect the corporation from liability exposure than the managers, who will be concerned about their own liability. The threat of vicarious liability lends credibility to the threat of the outside directors to report the manager's misconduct to the exchange. ${ }^{288}$ Indeed, the directors' fiduciary duties would probably require them to report if by doing so they could minimize the corporation's liability. Fimally, exchanges could re-

${ }^{284}$ See Arlen \& Kraakman, supra note 233, at 715 ("[S]trict liability gives a firm a strong incentive not to investigate or report its agent's wrongdoing: sucl policing measures cannot deter a wrong that has already occurred but will increase the firm's expected liability for it.").

${ }^{235}$ See Pitt \& Groskaufmanis, supra note 282, at 1646 ("The irony in this extensive reliance on vicarious liability is that it allows little room to reward the self-regulation it was developed to foster.").

${ }^{285}$ See C.Y. Cyrus Cluu \& Yingyi Qian, Vicarious Liability Under a Negligence Rule, 15 Int'l Rev. L. \& Econ. 305, 308 (1995) ("Because the agent knows that expost the principal always lias an imcentive to hide evidence from the court if she has any, then uuless some commitment to revealing evidence is made in advance by the principal, the agent should have no incentives to exert much care.").

${ }^{287}$ See Arlen \& Carney, supra note 10, at 728-29 ("Outside directors have less at stake if the firm were to fail, because they earn most of their income outside the firm. Indeed, because their reputational capital may be threatened by association with fraudulent activities, outside directors have incentives to deter, rather than to encourage, fraud."). There is evidence, however, that outside directors with the highest reputation-those with multiple directorships-are more likely to serve on boards of coinpanies that are sued for securities fraud. See Stephen P. Ferris et al., Monitoring by Directors with Multiple Board Appointments: Corporate Perfornance and the Incidence of Securities Fraud 24-30 (1999) (unpublisled manuscript, on file with the Virginia Law Review Association).

${ }^{228}$ See Arlen \& Kraakman, supra note 233, at 714-15 (criticizing strict vicarious liability on the grounds that, absent a reduction in liability, "the firm has every reason to announce policing measures but not implement then"). 
quire that any settlement be approved by a majority of disinterested outside directors. Such a requirenent would help ensure that company managers did not attempt to shift liability from themselves to the corporation. The overall effect of these measures would be to sever the hitigation interests of the corporation from the interests of its managers. Severing these interests would eliminate one of the principal problems with the class action settlement process-the ability of corporate managers to shift their hability to the corporation.

\section{Secondary Liability}

Putting enforcement in the hands of the exchanges also allows for reconsideration of the role of secondary hability. In Central Bank of Denver v. First Interstate Bank of Denver, ${ }^{289}$ the Supreme Court rejected aiding and abetting liability for violations of Rule $10 \mathrm{~b}-5 .{ }^{290}$ That rejection was based, in part, on the Court's concern that plaintiffs' attorneys were targeting "deep pocket" secondary defendants such as accountants, investment bankers, and lawyers, based not on their culpability but on their willingness and ability to pay settlements. ${ }^{291}$ Notwithstanding the lobbying of the SEC and the plaintiffs' bar, Congress refused to reinstate secondary liability for private causes of action in the Reforn Act, although it did give the SEC such authority. ${ }^{292}$ Moreover, Congress instituted a system of proportionate hability with the Refonn Act, giving further protection to secondary defendants. ${ }^{293}$ The combination of no aiding and abetting liability and proportionate liability has discouraged the plaintiffs' bar from naming secondary defendants in class action complaints-accountants, investment bankers, and lawyers are being sued much less frequently after Central Bank and the adoption of the Reforn Act. $^{294}$

\footnotetext{
289511 U.S. 164 (1994).

200 See id. at 191.

201 See id. at 188-90.

202 See 15 U.S.C. § 78t(f) (Supp. III 1997); see also Avery, supra note 6, at 351, 369 (discussing the SEC's efforts to restore aiding and abetting liability).

${ }^{203}$ See 15 U.S.C. $\& 78 \mathrm{u}-4(\mathrm{~g})(2)(\mathrm{B})$.

244 See Walker et al., supra note 1, at 651-52 (reporting a substantial drop in the number of suits against outside professionals).
} 
As with vicarious liability, secondary liability may have an important role to play in deterring securities fraud, if placed in the hands of an enforcer interested in deterrence. Secondary hability may encourage skepticism of corporate statements by the professionals whio certify such statements. ${ }^{295}$ Secondary liability could also encourage professionals to withhold cooperation in committing the fraud by refusing to certify the audit for an annual report or refusing to condone misstatements in SEC filings. ${ }^{296}$ Finally, secondary liability could encourage professionals to report suspected fraud to the exchanges. By reporting, they could reduce or eliminate their own liability. The SEC uses this strategy to encourage cooperation in its enforcement actions ${ }^{297}$ and accountants are required by the Exchange Act to report suspected fraud. ${ }^{298}$ Again, sanctions would need to be limited because professionals pass the cost of bearing such risks onto the corporation and because professionals bear heavy reputational losses from being involved in a fraud. ${ }^{299}$ Narrowly tailored, secondary liability could lower the overall cost of the enforcement regime while enhancing its effectiveness. Putting enforcement authority in the hands of the exchanges makes secondary liability a reasonable enforcement strategy rather than a search for a "deep pocket."

\section{Procedures}

Exchanges could also experiment with alternative procedural mechanisnis. Exchanges would likely prefer internal decisionmak-

${ }^{295}$ See Langevoort, Organized Illusions, supra note 25, at 159 ("Depending on the type of information in question, unanagement consultants, accounting firms, and law firms could offer a useful, though by no means fail-safe, therapeutic intervention.").

${ }^{296}$ See Kraakman, Gatekeepers, supra note 157, at 54 ("Accountants and lawyers are natural gatekeepers for fraudulent securities transactions that require audits or legal opinions in order to close [a deal] ....").

297 See id. at 57 n.9.

${ }^{208}$ See 15 U.S.C. $\S 78$ j-1(a) (Supp. III 1997) (establishing procedures by which accountants inust report suspected fraud). This provision was added by the Reform Act. On the trend toward imposing greater responsibilities on accountants to uncover fraud, see Elizabeth MacDonald, CPA Institute Tightens Rules To Find Fraud, Wall St. J., Nov. 13, 1996, at A6.

${ }^{29}$ See Langevoort, Organized Illusions, supra note 25, at 160 ("[I]nvestors pay heavily for third-party investigations, both in the direct fees paid by the issuer to the professionals for their time and effort, and in the risk premium to compensate for their liability exposure.”). 
ers or arbitration panels for deciding fraud enforcement actions, such as the ones they currently use in broker-dealer disciplinary proceedings and in disputes between broker-dealers and their customers. Arbitration before panels of exchange staff or before experienced businesspeople would produce more predictable judgments than randomly selected juries. Greater predictability would limit one of the principal factors inducing compamies to settle weak cases. ${ }^{300}$ Arbitration would also allow for confidentiality, so companies would not feel pressured to settle without first liaving an opportunity to defend themselves. A corporation's reputation would suffer only if an impartial tribunal first determined that it had committed fraud.

Exclianges could also require companies to cooperate witl imvestigations by their enforcement staffs before a formal complaint was filed, thus providing greater assurance that meritorious actions were brought and meritless claims dropped. ${ }^{301}$ Informal, targeted discovery of this type could be considerably less expensive than the massive discovery expense associated with class actions. Corporations would be inuch inore hikely to cooperate with an even-handed enforcer than with a revenue-maximizing plaintiffs' attorney. Exchanges, cognizant of expenses to issuers, would define tlieir document requests narrowly. The SEC currently rehes on sucl informal investigations, with the result that a substantial number of investigations are terminated at an early stage at mininal expense to the corporation. ${ }^{302}$

The Englisli Rule of awarding attorneys' fees and expenses to the prevailing party could also play an important role in an exchange-based regime. The English Rule would encourage exchanges to bring ineritorious claims, even where the sanctions obtained were likely to be slight, and encourage companies to re-

${ }^{300} \mathrm{Cf}$. Eth \& Dicke, supra note 22, at 112 (arguing that a defendant's incentive to settle increased by "concern that an unpredictable jury may be swayed by einotion to return a verdict against them," particularly in cases where insider trading is alleged).

301 Legislation would be necessary to give the exchanges subpoena power over third parties not in privity with the exchanges. See Doherty et al., supra note 163, at 641 (stating that exchanges currently rely on voluntary cooperation by third parties).

${ }^{302}$ See William R. McLucas et al., An Overview of Various Procedural Considerations Associated With the Securities and Exchange Commission's Investigative Process, 45 Bus. Law. 625, 628 (1990). 
sist nonmeritorious ones. ${ }^{303}$ The Enghish Rule would also help ensure that the exchanges' antifraud regimes were self-financing. If costs of enforcement exceed sanctions and fees recovered, exchanges could find themselves at a competitive disadvantage vis-àvis exchanges that provided unlisted trading in securities listed on other exchanges. Unless the regine is self-financing, exchanges could use unlisted trading to free-ride on the enforceinent efforts of the listing exchange. ${ }^{304}$ Such free-riding could jeopardize an exchange-based antifraud regime. ${ }^{305}$ The sanctions imposed by the antifraud regime should help finance some of the enforcement effort, as compensation would no longer be paid to investors. Using the English Rule for enforcement proceedings would supplement those revenues, as long as the exclianges chose their cases carefully.

The exchange miglit also want to experiment with different burdens of proof and even alter elements of the fraud claim itself, perhaps by lowering the state of mind requirements. Lowered scienter requirements would liave to be tied to smaller sanctions, but negligence-based liability would be insurable, thus protecting riskaverse managers. ${ }^{306}$ Witl reduced sanctions, a negligence standard for misstatements becomes a viable option because the risks of chilling corporate speecl and of encouraging excessive precautions

${ }^{303}$ See Clinton F. Beckner III \& Avery Katz, The Incentive Effects of Litigation Fee Shifting When Legal Standards Are Uncertain, 15 Int'l Rev. L. \& Econ. 205, 216 (1995) ("There is good theoretical reason to expect the British rule to encourage the filing of small and highly meritorious cases unlikely to be brought under the American rule, and to discourage complex suits with a low possibility of success."); Rosenberg \& Shavell, supra note 112, at 5 (arguing that the rule encourages suits with a high probability of prevailing).

${ }^{304}$ See Macey \& Haddock, supra note 43, at 348 n.168 ("If the New York Stock Exchange is providing a valuable certification service to consumers about the stocks it lists, then off-exchange trading permits non-member traders to 'free ride' by trading in listed securities without paying for this certification service.").

${ }^{305}$ The tendency for trading to congregate on the listing exchange mitigates this risk, see supra note 165 , but the risk of free-riding by other exchanges is nontrivial. See George I. Leffler, The Stock Market 558 (1951) ("The New York Stock Exchange maintains the listing standards which protect the public through release of imformation on balance sheets, profit and loss statements, corporate affairs, etc. It builds up the market for the stock; another exchange with hittle cost to itself capitalizes on this situation.").

${ }^{306}$ Insurance would reduce deterrence, but insurers may provide a useful monitoring function. See Holderness, supra note 123, at 118-23 (discussing the monitoring of corporate offlcials by D\&O imsurers). 
against misstatements are greatly diminished. ${ }^{307}$ These changes in the state of mind requirements would cause the definition of fraud enforced by the SEC to differ from that enforced by the exchanges. ${ }^{308}$ A lack of uniformity would impair predictability and make corporate counsel's job of advising clients on disclosure more difficult. $^{309}$ Given the limitations on SEC enforcenient, however, discrepancies between the exchanges' fraud standards and the SEC's are not likely to cause any serious problenis. Resource limits generally restrict the SEC's enforcement efforts to the most egregious cases, so the exchanges would be the dominant enforcement arm for garden variety frauds. Nonetheless, exchanges would want to tread lightly if they departed from the standards enforced by the SEC. In particular, a negligence standard should not be overused-while an individual can stop intentional violations at virtually no cost, prevention of negligent misstatements takes real resources. ${ }^{310}$ And, of course, stopping either kind of offense can be expensive for a corporation, which nust spend real resources to monitor its agents.

In sum, an exchange-based enforcennent regime promises more accurate imposition of sanctions that are more carefully tailored to the costs created by fraud on the inarket. Such a regime would promote deterrence by directly sanctioning nianagers responsible for the fraud and by using vicarious and secondary liability as a means to that end, rather than as a source of funding for settleinents and attorneys' fees. Just as important, placing enforceinent authority in the hands of the exchanges puts the forces of competition to work in improving procedures and clarifying standards.

\footnotetext{
${ }^{307}$ Alexander, supra note 88, at 1511 ("[A] sanctions regime could distinguish between injurers with different states of mind, puuishing intentional violations more severely than negligent or unintentional violations."); Mahoney, Precaution Costs, supra note 47, at 648 ("Were we to impose any liability for neghigent misstatements, however, it would have to be carefully limited to avoid overdeterring beneficial speech.").

${ }^{308}$ But see 15 U.S.C. $\S 78 \mathrm{~s}(\mathrm{~g})(1)$ (1994) (requiring that exchanges "coinply with the provisions of this chapter, the rules and regulations thereunder").

${ }^{309}$ The need for predictability is the principal rationale for recent legislation preeinpting state securities fraud class actions. See Levine \& Pritchard, supra note 4 , at $51-52$.

${ }^{310}$ See Darby \& Karni, supra note 63 , at 83 (comparing the costs of preventing incompetence and fraud).
} 
The exchange that deters fraud at the least cost will have an advantage over its rivals.

\section{HISTORY}

Critics of exchange antifraud enforcement might point to history to support their skepticism. Fraud, it is safe to say, will be a feature of the market in any era. Before the advent of the class action, only SEC oversight stood in the way of open-market fraud. ${ }^{311}$ And before the SEC was created in 1934, only state law enforcement was a barrier. ${ }^{312}$ Of course, the exchanges would always prefer to have enforcement paid for by taxpayers rather than by exchanges and their listed companies. ${ }^{313}$ Government antifraud enforcement is a massive subsidy to broker-dealers and the exchanges. But because public enforcement is funded through tax dollars, it is likely to be underprovided. ${ }^{314}$ Skeptics might ask why the exchanges did not take action to supplement government enforcement against the mampulations of the stock market in the 1920s. Other historical events also raise questions about the exchanges' incentives to protect investors. Why did the NYSE fix commission rates for inuch

${ }^{311}$ This overstates the case a little. Stuart Banner reports that "[b]y 1860 it was clear in New York, the state with the inost sercurities transactions, that a purchaser in the secondary inarket who paid too inuch as a result of the misrepresentations of corporate officers could recover froin those officers in a suit for fraud." Stuart Banner, Anglo-American Securities Regulation: Cultural and Political Roots, 1690-1860, at 242 (1998). Notwithstanding the availability of suit, proof of reliance and the absence of the class action device would have limited the deterrent effect of such a suit.

${ }^{312}$ See 1 William Harman Black, The Law of Stock Exchanges, Stockbrokers \& Custoiners 146-47 (1940) (discussing common law antecedents prohibiting fraud on the market); John R. Dos Passos, A Treatise on the Law of Stock-Brokers and StockExchanges 458-63 (1968) (same); Cliarles H. Meyer, The Law of Stockbrokers and Stock Exchanges 691-93 (1931) (describing New York law prohibitions against fraud on the market).

${ }^{313}$ See Michael E. Parrish, Securities Regulation and the New Deal 38-39 (1970) (reporting NYSE chairman's view in the 1920s that states should have primary responsibility for antifraud enforcement). The securities industry actively lobbied for antifraud ineasures. See id. at 22 (discussing the role of the Investinent Bankers Association in lobbying for the Martin Act in New York); see also Watson Washburn, Control of Securities Selling, 31 Mich. L. Rev. 768, 774 (1933) (advocating federal antifraud legislation because of the difficulties of coordinating state enforcement).

${ }^{314}$ See Carol J. Simon, The Effect of the 1933 Securities Act on Investor Information and the Performance of New Issues, 79 Am. Econ. Rev. 295, 297 (1989) ("[S]tate [blue-sky] statutes suffered from the lack of uniform standards and under-funded enforcement agencies."). 
of its history? And why did the NYSE threaten to abandon its "one share, one vote" rule when pressured by listing corporations? The answers to these questions implicate both the nature of the market and the pohtical organization of the exchanges. They also shed light on the limits of exchange regulation.

\section{A. Manipulation}

Commentators frequently assert that the NYSE of the 1920s was subject to widespread manipulation by corporate insiders, often in conjunction with market professionals (including speciahists), and that the NYSE did little to deter such manipulation. ${ }^{315}$ The revelations of the stock exchange hearings held by Congress in the 1930s revolved around these alleged manipulations. ${ }^{316}$ There are reasons, however, to be skeptical that manipulation was a serious problen 1 during the $1920 \mathrm{~s}$. The investigators responsible for the hearings had a clear political agenda-to make Wall Street the scapegoat for the nation's economic problenis. ${ }^{317}$ Worse yet, the investigators had only a limited grasp of the economics of securities markets. For exaniple, much of the hearings attempted to show that short

${ }^{315}$ See, e.g., Sobel, N.Y.S.E., supra note 203, at 285-88 (describing purported inanipulations); Leffler, supra note 305, at 321 ("In 1929, 107 stock issues of the [NYSE] were manipulated one or nore times by pools in which members of the Exchange were niterested."); id. at 322-23 (describing involvement of insiders and specialists in pool operations).

${ }^{316}$ See Ralph F. De Bedts, The New Deal's SEC: The Formative Years 20-21 (1964) (discussing "Senate Bear Hunt" for alleged manipulations). These manipulations occurred despite the fact that agreenents to manipulate stock were unenforceable under New York law. See Dos Passos, supra note 312, at 471-72 (describing a pooling agreenient to advance stock price through fictitious trading void as violating public policy). In addition, the NYSE had a rule against such nianipulations. See 1 Black, supra note 312 , at 892 ("Rule 612. No member or member firm or partner thereof shall directly or indirectly participate in or have any interest in the profits of a manipulative operation or knowingly manage or finance a manipulative operation.").

${ }^{317}$ See Harold Bierman, Jr., The Great Myths of 1929 and the Lessons To Be Learned 186-87 (1991) ("[A] major event such as a stock market crash gives rise to investigations and recommendations. There are likely to be too many emotions and political considerations tied to the investigations for them to be useful. The imvestigators are too close to the events to see the causal relationships."); Barrie A. Wigmore, The Crash and Its Aftermath 337 (1985) (Roosevelt's "first campaign speech did not have a single point that was not directed aganist the financial and business community"). 
selling by "bear pools" was responsible for the inarket crash. ${ }^{318} \mathrm{We}$ know today, however, that short selling plays an important role in maintaining the informational efficiency of the stock inarkets. ${ }^{319}$ Some of the short sales targeted during the hearings were simple hedging transactions by substantial investors trying to reduce their risk. ${ }^{320}$ Given the mvestigators' limited grasp of the economics of the stock market, the "findings" of these pohitical show trials should be taken with a grain of salt. ${ }^{321}$

Even assummg that manipulations were a common feature of the stock markets in the $1920 \mathrm{~s}$, however, the dynamics of these manipulations differ considerably from fraud on the market. Manipulations allegedly operated by creating the appearance of trading volume through fictitious sales for the purpose of imducing unsuspecting speculators to buy into a targeted stock. ${ }^{322}$ The manipulators would then unload their holdings at an inflated price, leaving the speculators to suffer the losses as prices inevitably collapsed. ${ }^{323}$

The key to understanding the failure of the NYSE to respond to such abuses is that the inanipulation was inevitably accompanied

${ }^{318}$ See Mahoney, Exchange as Regulator, supra note 160, at 1474 ("Many of the early sessions of the stock exchange hearings were devoted to a hunt for 'bear raiders' whom the Senate beheved to be the forces behind the stock market's sharp declines in 1932. The hunt was unsuccessful, became the object of ridicule in the press, and was quickly abandoned.") (footnotes omitted). Short selling was, of course, perfectly legal in New York. See Dos Passos, supra note 312, at 473-74 ("[B]y the statute of New York 'short' sales of securities are legalized.").

319 See Jonathan R. Macey et al., Restrictions on Short Sales: An Analysis of the Uptick Rule and Its Role in View of the October 1987 Stock Market Crash, 74 Cornell L. Rev. 799, 800 (1989). Short selling had its defenders at the time, but they are seldom given inuch credence during a time of inarket decline. See Richard Whitney, The Work of the New York Stock Exchange in the Panic of 1929, at 23-24 (speech delivered to the Boston Association of Stock Exchange Firms, June 10, 1930) ("If early in the fall a large short interest had accumulated, presumably stock prices would never have reached the great heights they did before the panic, and also added buying power during the panic would have been afforded by short covering.").

${ }_{320}$ See Biennan, supra note 317 , at 138-39 (describing hedging transaction treated as manipulation by Ferdinand Pecora, chief counsel for Senate investigation).

${ }^{321}$ See Paul G. Mahoney, The Stock Pools and the Securities Exchange Act, 51 J. Fin. Econ. 343 (1999); Bierman, supra note 317, at 134-39 (debunking supposed inanipulations investigated by Pecora hearings).

32 See Leffler, supra note 305 , at 320-29 (describing operations of manipulative pools); Note, Market Manipulation and the Securities Exchange Act, 46 Yale L.J. 624, 626-29 (1937) [hereinafter Note, Market Manipulation] (sanie).

${ }^{323}$ See Note, Market Manipulation, supra note 322, at 628 . 
by inflated trading volume. ${ }^{324}$ As a result, the NYSE membership benefited from the mamipulations as long as speculators were willing to participate. The puzzle is why the speculators would be willing to participate in a rigged game. For inany such speculators, the stock market may have served as an alternative to gambling, which was heavily restricted at the time. ${ }^{325}$ For these people, knowing that the gaine was fixed was unlikely to discourage thein from trading, as long as there was some prospect of winning big by selling out before the collapse. ${ }^{326}$ People continue to travel to Las Vegas and to purchase lottery tickets despite the knowledge that the odds are stacked agamst them. Such behavior is irrational unless the person has a preference for risk. The continued participation of speculators suggests that stock speculation may have value as a consumption good for risk takers beyond its investment value. ${ }^{327}$ As Craig Pirrong has persuasively argued, exchanges have little incentive to suppress an abuse that produced a profit for their members by enhancing trading volume. ${ }^{328}$ Then, as now, more trading meant inore commissions for broker-dealers. ${ }^{329}$

${ }^{324}$ See Leffler, supra note 305 , at 327-28 (discussing increased volume accompanyimg manipulations).

${ }^{225}$ See Sobel, N.Y.S.E., supra note 203, at 248 (coinparing stock market speculation during the 1920 s to gambling).

${ }^{326}$ Robert Warshow indicates that brokers were frequently paid by pools to spread the word that a pool was operating in a stock, "a poimt which served usually to induce the customer to purchase." Warshow, supra note 203, at 47 . That public imvestors would participate in a market, knowing that a pool was operating, suggests a preference for risk.

${ }^{327}$ See Jonathan Clements, Getting Going, Wall St. J., Sept. 22, 1998, at C1 (citing Steven Thorley, a finance professor at Brighan Young University, for the proposition that "soine investors may be akin to ganiblers flocking to Las Vegas. These gamblers know they are unlikely to inake inoney. But they enjoy themselves nonetheless.").

${ }^{323}$ See Pirrong, Self-Regulation, supra note 162, at 152-54 (arguing that mampulation may lead to increased trading volume by marginal traders despite welfare losses to infraniarginal traders). Managers are also unlikely to have incentives to discourage speculative trading. See Kahan, supra note 230, at 1514 ("Simce stockholders like speculative trading and simce such trading does not affect the company's profits, managerial imcentives to limit it are likely to be low or nonexistent."). Under the antifraud regime proposed here, however, if the exchange engaged in excessive antifraud enforcement as a means of encouraging trading, that excessive enforcement would reduce corporate profits, thus encouraging managers to switch exchanges.

${ }^{320}$ See Stuart Banner, The Origin of the New York Stock Exchange, 27 J. Legal Stud. 113, 126 (1997) ("For the New York brokers, who earned their hiving by trading, more trades meant more money."); Warshow, supra note 203, at 71 (arguing that 
Exchanges' incentives to suppress this abuse were further undercut by the comphicity of the exchange specialists in the manipulations. ${ }^{330}$ Specialists ordinarily serve as a barrier against the adverse selection problems posed by information asymmetries because asymmetries tend to inflate the bid/ask spread. ${ }^{331}$ Only by bribing the specialists to join the conspiracy could manipulations be expected to succeed. ${ }^{332}$ Given the specialists' doninant status in the internal politics of the exchange at the time, reform was unlikely if the specialists were opposed to it. ${ }^{333}$ Further evidence that brokerdealers had reason to tolerate manipulations is that the passage of the Exchange Act-with its strong antimanipulation provisionsresulted in significant declines in NYSE and AMEX seat values. ${ }^{334}$

the broker "will try, wherever consistent with the prevailing ethics of his line, to get as much trading as possible, so that he may get more commissions").

${ }^{330}$ See Warshow, supra note 203, at 31 ("Specialists capitalized the information acquired because of their confidential position. This situation led to a great many abuses, and the Senate Investigation of 1933 uncovered many instances where the knowledge of the specialist, acquired as a result of his position, was used for manipulative purposes, either for himself or a syndicate.").

${ }^{331}$ See Benveriste et al., supra note 189 at 64 (arguing that specialists can reduce adverse selection problems created by informed trading by inducing brokers to reveal reasons for trades); see also Note, The Downstairs Insider: The Specialist and Rule 10b-5, 42 N.Y.U. L. Rev. 695, 698-99, 706-10 (1967) (discussing the informational advantage of specialists).

${ }^{332}$ See Warshow, supra note 203, at 30-31 ("Previous to regulation, the specialist assumed a great importance to syndicates and pools. His knowledge of all orders in a given stock, which he was not forced to reveal to other brokers, gave him a weapon which was a great aid to syndicates and trading pools. It became the custom to imclude the specialist im a pool, or enlist his cooperation, if only as a preventive measure."); Leffler, supra note 305 , at 323 (discussing bribes paid to specialists).

${ }^{333}$ See De Bedts, supra note 316, at 144-45 (noting disproportionate influence of the "Old Guard" in NYSE pohtics; Old Guard was made up of floor traders, specialists, and bond brokers); Parrish, supra note 313, at 119 (stating that the leadership of the NYSE "was composed almost entirely of floor traders and specialists"); id. at 217 ("The SEC, for its part, viewed the excessive leverage of specialists and floor traders as the primcipal obstacle to more effective enforcement and self-regulation by the New York Stock Exchange.”); Sobel, N.Y.S.E., supra note 203, at 18 (“although specialists and private traders accounted for only half the N.Y.S.E. seats, two-thirds of the governors came from these two groups"). The NYSE nonetheless adopted a number of reforms during the Senate hearings into its operation. See De Bedts, supra note 316, at 63 (describing rules adopted during hearings: "members would not be permitted to take part in pool operations; no specialist might acquire any stock for which he was the specialist broker, nor could the specialist disclose inforination im regard to an order entrusted to him").

${ }^{334}$ See G. Willianı Schwert, Public Regulation of National Securities Exchanges: A Test of the Capture Hypothesis, 8 Bell J. Econ. 128 (1977). Part of this decline in seat 
Reduction in seat values is not the result one would have expected from government regulation intended to "restore investor confidence," i.e., willingness to trade over the exchanges. ${ }^{335}$ Tolerating inanipulation nay have been profitable for broker-dealers.

The NYSE's failure to respond to manipulations was exacerbated by the fact that exchange rules were enforced by the Board of Governors, made up of exchange members. ${ }^{336}$ This arrangement left enforcement vulnerable to intensive lobbying efforts that undermined its effectiveness. ${ }^{337}$ Effectiveness was also limited by the fact that the exchange could not impose sanctions on nonmeinbers. $^{338}$ The exchange's enforcement authority was strictly limited:

values may be attributable to the SEC's open hostility at the time to the goal of liquidity. See De Bedts, supra note 316 , at 158 (discussing criticisms of liquidity by SEC chairman William O. Douglas and in staff reports). In this regard, it is worth noting that institutional investors-who should have been primary beneficiaries of regulation-were critical of the Exchange Act. See C. John Kuhn, The Securities Act and Its Effect Upon the Institutional Investor, 4 Law \& Conteinp. Probs. 80, 85 (1937) ("[I]t is the consensus of opinion among tramed security buyers that regulations [under the Exchange Act] ... have a restrictive effect upon markets outweighing the benefits gaimed.").

${ }_{335}$ The Exchange Act was a resounding failure at restoring investor confidencethe volume of trading remained below 1929 levels for another three decades. See Sobel, N.Y.S.E., supra note 203, at 68, 235 (average daily trading volume in 1955 was 1.7 million shares below 1929 averages).

${ }^{336}$ See Meyer, supra note 312, at 46-49 (describing the organization of the NYSE during the 1920s).

${ }^{377}$ See Pirrong, Self-Regulation, supra note 162, at 158-63 (discussing theoretical reasons why exchange enforcement may be susceptible to rent-seeking by members); id. at 189-90 (arguing that the NYSE did not historically act to prevent "corners" in NYSE-listed stocks); see also Note, Market Mampulation, supra note 322, at 640 ("[T]he Exchange is not always a wholly disinterested arbiter in conflicts involving the interests of its members."). But see Leffler, supra note 305 , at 320 (discussing exchange actions to counteract atteinpts to corner a market in the 1920s).

${ }^{338}$ See Dos Passos, supra note 312, at 39 (noting that the exchanges were limited to "the power to make rules and regulations for their internal government"); see also Edınund W. Kitch, Coinpetition Between Securities Markets: Good or Bad?, in The Future for the Global Securities Market 233, 237 (Fidelis Oditah ed., 1996) ("Part of the effort to promote the market will include efforts to convince potential users that the market is a fair place to deal, that prices are not subject to manipulation, and that some traders do not have an unfair or improper advantage. The ability of the Exchange to act in these areas, however, is limited since its powers are only over exchange members."). The exchanges could adjudicate disputes between members and noumembers where the nonmember had agreed to subject himself to the exchange's authority. See Dos Passos, supra note 312, at 813 (describing the NYSE rule providing for resolution of disputes). 
It would seem entirely reasonable to confine and limit the jurisdiction of the Stock Exchange to those matters which arise between its members in the course of their busmess with each other as Brokers; otherwise its judicial powers might be extended to embrace every affair of human life, which was never contemplated, and which the law would not permit. ${ }^{339}$

In addition, the exchange had no power to subpoena witnesses who were not members of the exchange. ${ }^{340}$ The courts would not tolerate infringement by the exchanges on judicial authority to resolve private disputes. ${ }^{341}$ Thus, exchange enforcement was hampered both by the exchange's organization and its limited jurisdiction. The imstitutional structure of the exchanges has changed since the 1920 s - they now have separate enforcement divisions staffed by professionals rather than member broker-dealers. ${ }^{342}$ These professional enforcement divisions give added credibility to the exchanges' promises to enforce their rules consistently and evenhandedly.

Despite its failure to take strong steps agamst mampulation, the NYSE did take other measures to combat information asymmetries. By the middle of the nineteenth century, the NYSE had a rule prohibiting members from receiving communications during the trading session, thus ensuring that no member would have an informational advantage over another. ${ }^{344}$ Fictitious trades were also prohibited ${ }^{345}$ and members guilty of fraud were subject to expulsion. ${ }^{346}$ And from the earliest days of the exchange, the NYSE

${ }^{339}$ Dos Passos, supra note 312 , at 75-76.

${ }^{340}$ See id. at 76.

${ }^{3+1}$ See id. at 76-78 (discussing cases in which courts limited exchanges' authority).

${ }^{342}$ See Parrish, supra note 313, at 217-18 (discussing reorganization of the NYSE in 1938); see also Doherty et al., supra note 163, at 638-39 (discussing inodern organization of the NYSE).

${ }^{343}$ See Leffler, supra note 305 , at 553-54 (attributing the decline in manipulation to the introduction of a full-time staff charged with inonitoring markets).

${ }^{344}$ See Banner, supra note 329, at 124.

${ }^{345}$ See Dos Passos, supra note 312, at 821 (describing Article 16 of the NYSE rules prohibiting fictitious sales). This rule had been part of the original constitution of the NYSE's predecessor in 1817. See Sobel, The Big Board, supra note 64, at 30-31 ("'Wash sales'-the sale of a security by one broker to another who acted for him or his client, in order to give the impression of a transaction when one had not taken place-were forbidden.").

${ }^{346}$ See Dos Passos, supra note 313, at 823 (describing Article 20 of the NYSE rules, specifying the penalty for fraud). 
bolstered its reputation among investors with its atteenpts to reduce the potential for fraudulently induced price distortions. ${ }^{347}$ The NYSE waged a long campaign agamst the traditional secrecy of corporate managers. ${ }^{348}$ The moveinent toward requiring greater disclosure by histing companies was slowed, however, by the fact that changes in listing agreements did not work retroactively. ${ }^{349}$ Until 1939, coinpanies paid a one-time listing fee that gave them the right to a listing in perpetuity. ${ }^{350}$ In addition, other exchanges imposed substantially lower listing standards than did the NYSE,

${ }^{3 * 7}$ See John Hanna, The Securities Exchange Act as Supplementary of the Securities Act, 4 Law \& Contemp. Probs. 256, 258-59 (1937) (summarizing NYSE listing procedures circa 1932); Banner, supra note 329, at 128-29 (discussing nineteenthcentury procedures for screening companies wishing to be added to the trading list); R.C. Michie, The London and New York Stock Exchanges 198 (1987) ("[T]he Stock Exchange was extremely careful to vet the stocks and bonds it admitted quotation, seeking for reasons to refuse rather than accept."); id. at 272-73 (comparing the NYSE's stringent listing standards with lower standards followed in London); Walter Werner \& Steven T. Smith, Wall Street 145 (1991) ("The [predecessor of the NYSE] deserves considerable credit in the movement toward corporate disclosure. Its requirements for listing securities involved releasing increasing amounts of information to the public.").

${ }^{348}$ The traditional secrecy of corporate officers is far removed from the steady stream of disclosure we now see from corporations. George Leffler describes this attitude of secrecy:

The evolution of listing requirements of the New York Stock Exchange furnisles an interesting chapter in the history of American busimess practices and ethics. Directors of American corporations in the early years of our national history shrouded the affairs of their organizations in an almost impenetrable cloak of secrecy. What they did, what they earned, how many assets they controlled, and similar matters were facts whicli they considered to be purely private affairs. To permit the public or their own stock holders to know even the barest details of their financial affairs was unthinkable; this attitude clianged slowly. It was the basis for an almost continuous struggle between the Exchange and the listed companies from 1869 to 1933.

Leffler, supra note 305, at 428-29; see also Sobel, The Big Board, supra note 64, at 178 (discussing businessmen's aversion to disclosure).

${ }^{349}$ See Leffier, supra note 305, at 433 ("Companies could be lield only to agreeinents which they had signed; soine of these were entered into a great many years ago. If new and additional agreements were formulated by the Exchange, old listed coinpanies could not be compelled to coinply except by Exchange persuasion, or if they applied for further listing of stock."); Parrish, supra note 313, at 40 ("Recommendations by the listing committee were never retroactive."); Comment, Stock Exchange Listing Agreements as a Vehicle for Corporate Governance, $129 \mathrm{U}$. Pa. L. Rev. 1427, 1437 n.49 (1981) (sanie).

${ }^{350}$ See Leffier, supra note 305, at 427. 
and the over-the-counter market imposed no standards at all. ${ }^{351}$ The combination of these factors undoubtedly reduced the NYSE's bargaining leverage with coinpanies in pushing for greater disclosure. More fundamentally, the failure of the securities markets to impose more stringent disclosure requirements also suggests that the demand for such disclosure among investors was limited.

Despite these obstacles, the NYSE eventually was able to require listed corporations to provide regular balance sheets and other financial data to stockholders: ${ }^{352}$

Beginning with the abolishment of unlisted trading in 1910, the Exchange's Committee on Stock List carried out a vigorous and successful campaign to improve the quality and quantity of disclosure. ... After the NYSE abohished unlisted trading, most of the Exchange's unlisted companies (in other words, those companies with the strongest desire not to disclose) applied for a full listing even though it meant complying with the disclosure requirements. ${ }^{353}$

The provision of this information by formerly unlisted coinpanies went far toward reducing information asymmetries. The NYSE's requirement that those financial statements be audited also provided a substantial impediment to fraud. ${ }^{354}$ The value of the NYSE's listing requirements is testified to by the fact that Congress closely tracked the NYSE disclosure requirements when it drafted the Exchange Act.

${ }^{351}$ See id. at 432-33.

352 See Simon, supra note 314 , at 298 tbl.1 (listing the chronology for the introduction of the NYSE disclosure requirements); Sobel, The Big Board, supra note 64, at 132 (noting that annual reports were required in 1895, while earnings statements and balance sheets were required for listings as of 1900).

${ }^{353}$ Mahoney, Exchange as Regulator, supra note 160, at 1469-70.

${ }^{354}$ The policy was adopted in 1928; by $1931,83 \%$ of listed coinpanies were coinplying, and im 1932 the NYSE made the policy mandatory for all newly listed companies. See Leffler, supra note 305 , at 430 (discussing the NYSE's struggle to force compames to submit to imdependent audits).

${ }^{355}$ See George J. Benston, Required Disclosure and the Stock Market: An Evaluation of the Securities Exchange Act of 1934, 63 Am. Econ. Rev. 132, 133 (1973) (listing Act's disclosure requirements). In addition, many states exempted securities from registration im that state if they were listed on the NYSE. See Parrish, supra note 313, at 24-25. For criticisms of this exemption, see Olga M. Steig, What Can the Regulatory Securities Act Accoinplislı? 31 Mich. L. Rev. 775 (1933). The NYSE's listing agreement at the time can be found in 1 Black, supra note 312, at 998-1027. 
It is also important to remember that in the early part of this century the NYSE was a market primarily devoted to trading bonds rather than stocks. ${ }^{356}$ Not until 1928 did the volume of new stock issues surpass the volume of new bond issues histed on the NYSE. ${ }^{357}$ And this shift marked a sea change: As late as 1927, the volume of new bond issues was more than double that of new stock issues. ${ }^{358}$ The shift toward trading in equities seems to have caught broker-dealers by surprise; the industry lacked the appropriate mechamisms for dealing with the greater informational requirements of trading in stocks. ${ }^{359}$ For bond trading, the information required by the NYSE listing standards was likely to be all that was relevant to the average imvestor because it would give a sufficient basis for assessing default risk. ${ }^{360}$ A supplementary systein of anti-

\footnotetext{
${ }^{356}$ See Wigmore, supra note 317 , at 106 (discussing predominance of bond markets through the 1920s: "The attention attracted by the drama of the 1929 stock market distorts the popular image of financial inarkets at that time, for the bond market was much more important to the capital-raising process than the stock market."); Michie, supra note 347, at 195 tbl.7.1 (comparing stock and bond sales on the NYSE from 1879 to 1913); id. at 231 ("Within the securities [the NYSE] quoted, there was a concentration upon bonds rather than stocks. In 1913, while the Stock Exchange provided a inarket for only 35 per cent of the nation's stocks, it listed 63 per cent of its bonds.").
}

35 See Gregg A. Jarrell, The Economic Effects of Federal Regulation of the Market for New Security Issues, 24 J.L. \& Econ. 613, 618 tbl.1 (1981); see also Parrish, supra note 313, at 39 ("In 1917, stock issues constituted less than one-third of all listings on the New York Stock Exchange. By 1926 stock issues had risen to 43 percent of all listings. In that same year, the total value of equity shares listed exceeded the total value of listed bonds.").

3s8 See Jarrell, supra note 357, at 618 tbl.1.

${ }^{359}$ See Parrish, supra note 313, at 32-33 (discussing difficulties of brokerage houses in evaluating stocks).

${ }^{360}$ The following investment advice froin the 1930s suggests that the NYSE's listing requirements were entirely sufficient for bond traders:

Because of the fact that the possibilities of speculative profit are very limited where a bond is bought at the issuance price, the risk should in proportion be sinall. For that reason, the terms of the bond as well as the general credit of the company should be carefully scrutinized.

Warshow, supra note 203, at 20. Practice with regard to bonds has not changed significantly. Cf. Securities Act Release No. 6331, 46 Fed. Reg. 41,902, 41,910 (Aug. 18, 1981) (fixed incoine securities purchased on the basis of yields and ratings). Speculation in bonds would have been limited to those issued by companies in financial distress. See Warshow, supra note 203, at 92 ("Speculation may be indulged in bonds, particularly bonds of bankrupt compamies or companies whose position is not absolutely secure and whose bonds have therefore depreciated seriously in value."). Most speculation was confined to preferred and common stocks. See id. at 93. 
fraud enforcement would have been largely superfluous to aftermarket bond imvestors. ${ }^{361}$ The regulatory apparatus of the NYSE simply lagged behind the shift in the market from bonds to stocks with stock trading's greater informational demands. ${ }^{362}$ The NYSE adopted a number of antifraud rules in the wake of the Exchange Act as equities trading came to dominate. ${ }^{363}$

The most sophisticated purchasers of exchange regulatory services-imstitutional investors-were overwhelmingly invested im debt, not equity, during the $1920 \mathrm{~s}^{364}$ That preference for debt over equity was accentuated by the passage of the Securities Act in 1933. The Securities Act caused an increase in the ratio of bonds to equity, and it seems to have generally reduced the riskiness of imvestments available to the public. ${ }^{365}$ That trend has now reversed and institutional imvestors have shifted toward holding equity. ${ }^{366}$

${ }^{361} \mathrm{Cf}$. Kitch, supra note 338, at $234 \mathrm{n} .1$ ("Historically, the Exchanges were places for transactions in bonds, and originally that meant government bonds and closely related obligations. It was only after Exchanges became places mostly for transactions in equities that deinands for more extensive public regulation arose.").

${ }^{362}$ Cf. Parrisl1, supra note 313 , at 39-40 (discussing the difficulties posed for the NYSE's investigative staff by the shift to equities).

${ }^{363}$ Rule 603 of the NYSE, adopted November 9, 1938, states that "[n]o member or ineinber firm or partner thereof shall employ any representative of the press for the purpose of obtaining advance or confidential information." Black, supra note 312, at 890. Rule 606, adopted at the same time, states that "[n]o member or meinber firm or partner thereof shall circulate in any manner rumors of a sensational character." Id. at 891.

${ }^{364}$ See Michie, supra note 347, at 233-34 (explaining the use of NYSE-listed bonds by banks and life insurance companies as repositories for short-term investments). Fiduciaries were limited in the type of securities that they could hold. See John Langbein \& Richard A. Posner, Market Funds and Trust-Investment Law, 1976 Am. B. Found. Res. J. 1, 4 (arguing that eighteenth and nineteenth-century judges and legislators had a bias for "safe" imvestments, defined as long-term fixed-income goverument bonds or inortgages). Life insurance compamies, for example, were at that time forbidden to hold common stocks. See Wigmore, supra note 317, at 336.

${ }^{365}$ See Jarrell, supra note 357, at 664 ("All imdustry groups imcreased their usage of bonds, especially during the first ten years following 1934. If this is evidence of a regulatory effect, the regulation causes a substitution froin equity financing and toward bond and preferred stock financing on a more or less uniform basis across industries.").

${ }^{366}$ Poser, supra note 155, at 898 (noting rise in institutional ownership and "movement of institutional portfolios away froin fixed income securities and into equities"). 
Thus, the demand for the antifraud regulation by informed consumers of exchange services has greatly increased since the $1920 \mathrm{~s}^{367}$

More important than the imcreased demand for regulation, however, is a fundamental distinction between fraud on the market and the manipulations of the 1920s. Fraud on the market, unlike manipulation, diminishes trading volume rather than enhancing it. Under these circumstances the members of the exchange, and particularly the specialists, are unlikely to be as tolerant of abuses. The substantial investments of the exchanges in monitoring systems for detecting insider trading are a testament to the exchange members' lack of tolerance for information asymmetries that reduce trading volume. ${ }^{368}$ The information asymmetries created by fraud on the market pose a similar problem for the exchange membership. Therefore, whereas exchange members might have been willing to tolerate the mampulations of the 1920 s, the members will not be willing to tolerate fraud on the market. ${ }^{369}$

\section{B. Fixed Commissions}

The exchanges will not oppose all practices that reduce trading volume. The fixed commissions imposed by the NYSE until 1975, for example, clearly limited trading volume by artificially increas-

${ }^{367}$ There were also alternative mechanisms for certifying the credibility of corporate statements and for reducing information asymmetries in the 1920s. Investment bankers bonded their reputation to a company by serving on its board of directors and investing in the company. See Carlos D. Ramirez, Did J.P. Morgan's Men Add Liquidity? Corporate Investment, Cash Flow, and Financial Structure at the Turn of the Twentieth Century, 50 J. Fin. 661, 667 (1995) (demonstrating that the presence of J.P. Morgan representatives on a firm's board reduced its cost of capital).

${ }^{368}$ See Macey \& Haddock, supra note 43, at 346 ("The [NASD] has a Market Surveillance Department with computer facilities that momitor all transactions reported on the consohidated tape through the [NASDAQ] system."); see also Macey \& Kanda, supra note 8 , at 1020-22 (discussing exchanges' comparative advantage in providing centralized monitoring of trading).

${ }^{36}$ Other exchange rules also reduce information asymmetries. Conipanies are required to disclose significant events that may affect trading. See American Stock Exchange Company Guide $\$ \S 401,402$ (1979); National Association of Securities Dealers Manual (CCH) § 5, Schedule D, Part II, 1T1806A, at 1572-74 (1994); New York Stock Exchange Listed Conipany Manual $\S 202.05$ (1992) [hereinafter NYSE Listed Company Manual]. NYSE-listed conpanies also must have audit committees consisting solely of independent directors. See NYSE Listed Company Manual, supra, $\$ 303.00$. Oversight by mdependent audit committees enhances the credibility of the information provided by the audit. 
ing the price of trading. ${ }^{370}$ But those reductions in volume were accoinpanied by supernormal profits for exchange inembers and were supported by the SEC's validation of rules discouraging competition. Exchanges are not charities: They are unlikely to protect investors if the protection comes at the expense of their members' profits, particularly if the SEC acquiesces. ${ }^{371}$ Fraud on the niarket, in contrast to the fixed commissions, provides no monopoly benefits to broker-dealers to offset the decline in volume it causes. In addition, it is well to remeinber that the end of fixed commissions on the NYSE was brought about by competition from other exchanges and the over-the-counter niarket. ${ }^{32}$ By the time the SEC finally acted to prohibit fixed commissions, it was essentially ratifying a fait accompli, as the largest members of the NYSE no longer supported price fixing. ${ }^{373}$ While competition appears to have harmed the collective interest of the NYSE's membership, ${ }^{374} \mathrm{com}$ petition from other markets nonetheless forced the NYSE to protect investor interests by eliminating fixed commissions. Competition is likely to be particularly effective in cultivating investor

${ }^{370}$ See 6 Louis Loss \& Joel Seligman, Securities Regulation 2851-80 (3d ed. 1990) (discussing the demise of fixed commissions). Attempts to fix prices for commissions go back to the earliest days of the NYSE. See Banner, supra note 329, at 114-15 (explaining late-eigliteenth century attempts at cartelization). Of course, the basic structure of the exclianges-limiting trading only to meinbers-increases the costs of trading because exchanges will limit the number of members in order to extract monopoly rents. See Pirrong, Organization, supra note 162, at 2 . The value of exchange seats relative to exchange assets suggests that exchange members succeed im extracting monopoly rents. See id. at 32.

${ }^{311}$ But see Mahoney, Exchange as Regulator, supra note 160, at 1487-88 (arguing that the purpose of the fixed commissions rules may liave been to force informed traders (who would attempt to trade anonymously and in large volume) to subsidize uninformed traders); Kitch, supra note 338, at 237 ("Agreed minimum commissions help to ensure that attracting increased business to the Exchange will in fact be profitable to members, that members will not simply coinpete away the gains from their own success.").

372 See Jarrell, supra note 194, at 274.

${ }^{373}$ See id. at 298 (major "brokerage firms were largely beneficiaries of the $1975 \mathrm{de}-$ regulation of NYSE brokerage rates"); Mahoney, Exchange as Regulator, supra note 160 , at 1494 ("Pressure from institutional investors had made a mockery of fixed commissions well before 1975, and competition froin the new NASDAQ market and other over-the-counter markets had made exchange members less enthusiastic about the practice."); Sobel, N.Y.S.E., supra note 203, at 370 (compiling defections of major brokerage houses).

${ }^{374}$ See Jarrell, supra note 194, at 296 (value of NYSE seat declined by $50 \%$ after deregulation). 
protection when an important segment of the exchange membership benefits from that investor protection.

\section{Nonvoting Common Stock}

The final historical example commonly offered as a critique of exchange regulation is the demise of the NYSE's restrictions on nonvoting common stock. ${ }^{375}$ For over fifty years the NYSE prohibited histed companies from issuing common stock without voting rights. ${ }^{376}$ The NASDAQ did not impose similar restrictions in its histing agreement. ${ }^{37}$ In the 1980s, General Motors ("GM"), an NYSE company, refused to comply with the rule prohibiting nonvoting common stock, and the NYSE essentially ignored GM's defiance of the rule. ${ }^{378}$ The NYSE was unwilling to enforce its rule unless the AMEX and NASDAQ prohibited the practice as well. ${ }^{379}$ The SEC responded by adopting a rule of its own prohibiting nonvoting common stock. ${ }^{380}$ That rule was struck down by the United States Court of Appeals for the District of Columbia Circuit as being beyond the Commission's statutory authority. ${ }^{381}$ Subsequently, the NYSE, AMEX, and NASDAQ agreed upon a rule limiting nonvoting common stock. ${ }^{382}$ They did so, however, only after the pressure from corporations for the issuance of nonvoting common stock had declined as the takeover fever of the late 1980s subsided.

The NYSE's failure to hold the line on nonvoting common stock raises questions about the exchanges' credibility in enforcing inves-

${ }^{375}$ See, e.g., Kahan, supra note 230, at 1514 n.30 (arguing that the demise of the NYSE's "one share, one vote" rule rebuts arguments in favor of stock exchange regulation).

${ }^{376}$ See Stephen M. Bainbridge, The Short Life and Resurrection of SEC Rule 19c-4, 69 Wash. U. L.Q. 565, 569 (1991) (discussing origins of NYSE rule against nonvoting common stock); Leffler, supra note 305, at 431 ("Since 1926 the Exchange has refused to list common stocks which do not carry voting rights.").

${ }^{377}$ See Bainbridge, supra note 376, at 575 .

${ }^{378}$ See id. at $576-77 \&$ n.54.

${ }^{379}$ See Fischel, Organized Exchanges, supra note 160, at 121 ("The NYSE has stated that it would prefer to retain the prohibition, but only if other exchanges adopted the prohibition or were forced to do so by federal regulation.").

${ }^{380}$ See Exchange Act Release No. 34-25891, 53 Fed. Reg. 26,376 (1988), reprinted in [1987-1988 Transfer Binder] Fed. Sec. L. Rep. (CCH) I 84,247, at 89, 208 (July 7, 1988). ${ }^{381}$ See Business Roundtable v. SEC, 905 F.2d 406 (D.C. Cir. 1990).

30 See SEC Approves New Voting Rights Rule, Adopts Rule Streamlining SRO Regulation, 26 Sec. Reg. \& L. Rep. (BNA) 1708 (Dec. 23, 1994). 
tor protections. ${ }^{383}$ Nonvoting common stock arguably has a substantial adverse impact on investor welfare because of its tendency to undermine managerial accountability. ${ }^{384}$ If the NYSE was unwilling to enforce this investor protection provision, would it be willing to enforce prohibitions against fraud on the inarket in the face of outraged responses from corporate inanagers complaining that they are being unfairly targeted?

This question raises a substantial concern. The exchanges cannot be looked to as a cure-all for every problem of corporate governance. A distinction must be drawn between the enforcement of investor protection provisions that enhance only investor welfare and those that also enhance broker-dealer profits. ${ }^{385}$ Prohibitions against nonvoting common stock may protect the welfare of stockholders, but there is no reason to believe that such prohibitions increase trading volume. ${ }^{386}$ In contrast, the central rationale for prohibitions against fraud on the market is their tendency to increase volume.

\section{Summary}

The institutional structure of the exchanges, governed by their members, suggests that the exchanges will regulate in the interest of investors when investors demand such regulation and when regulation benefits well-organized groups within the exchange's

${ }^{339}$ See Macey \& Kanda, supra note 8, at 1039 ("[E]ven if the NYSE were to attempt to re-enter the competition to promulgate rules of corporate governance, the Exchange now completely lacks credibility as a result of the $19 c-4$ controversy.").

3s See Jeffrey N. Gordon, Ties that Bond: Dual Class Common Stock and the Problem of Shareholder Choice, 76 Cal. L. Rev. 1, 23-29 (1988). But see Fischel, Organized Exchanges, supra note 160, at 142-52 (arguing that dual class common stock may benefit certain firms).

${ }^{305}$ Where regulation directly benefits the exchange membership, exchange enforcement can be incredibly effective. For example, no NYSE member firms became insolvent during the 1929 crash, despite the enornous declines in stock prices. See Whitney, supra note 319 , at 25 . Insolvency, of course, would have harmed the brokers with whom an insolvent member traded. Brokerage firms began to fail only when the general economic downturn took its toll on busmess. See Wigmore, supra note 317, at 237-38 (detailing brokerage failures in 1931).

${ }^{386}$ Indeed, nonvoting common stock may be traded more frequently, as dissatisfied shareholders have little recourse other than sale. 
membership ${ }_{388}^{387}$ or when there is substantial pressure from the SEC to regulate. ${ }^{388}$ In the cases of market mampulation and fixed commissions, brokers expected losses from increased regulation. And dual-class common stock was unlikely to have any effect on trading volume. In the case of fraud on the market, however, the specialists and floor brokers are well-organized groups that benefit from regulation in the form of increased trading volume. Moreover, it is safe to assume that the SEC will put substantial pressure on the exchanges to regulate effectively, an important constraint given the SEC's oversight authority over the exchanges. These dual pressures give assurance that the exchanges will be vigorous antifraud enforcers.

\section{AlTERNATIVES TO EXCHANGE ENFORCEMENT}

Another potential objection to my proposal is that there nay be alternatives that reduce the cost of the class action regime without the risks that accompany antifraud enforcement by the exchanges. This Part compares my proposal with potential alternative reforms.

\section{A. Reforming Class Actions}

\section{Limiting Damages}

Both Janet Cooper Alexander and Donald Langevoort have argued that reducing the ineasure of dainages for fraud on the market class actions would ameliorate some of the inefficient incentives created by such suits. ${ }^{389}$ As Langevoort puts it, "[f]ew rational investors would opt for a system that so systematically overcompensates when they know that investors generally will be funding those payinents. And no rational investor would opt for an expensive litigation system to accomphish it."390

I agree that abandoning the compensatory paradigm and reducing sanctions from the damages measure currently used is an essential beginning toward a deterrence policy that would discourage

387 See Pirrong, Efficient Scope, supra note 162, at 254-55 (arguing that exchanges are unlikely to regulate where a well-organized group benefits from abuse).

388 See Pirrong, Self-Regulation, supra note 162, at 193-95 (noting that exchanges regulate manipulation more strictly under government oversight).

${ }_{389}$ See Alexander, supra note 88; Langevoort, Capping Damages, supra note 52.

390 Langevoort, Capping Damages, supra note 52, at 650. 
secondary market fraud at the least social cost. Reducing damages, however, goes only part of the way. The incentives of plaintiffs' attorneys cannot be reconciled with an effective enforcement regime because-whatever the measure of damages-pursuing the goal of coinpensation means that they will only be interested in financial recovery. That focus on financial recovery ensures that the deterrence benefits of securities class actions will come at a high price. And even under a reduced measure of damages, corporate managers will contimue to have an incentive to settle fraud cases with their shareholders' money, which further undermines deterrence. Alexander suggests that this tendency can be reduced by making fraud penalties uninsurable and unindemnifiable. ${ }^{391}$ Policing such a prohibition would pose a difficult administrative taskindemnification can be easily disguised as compensation, perhaps in the form of a bonus.

The credibility of the enforcer matters here. A sanction imposed in an action brought by a plaintiffs' attorney can be discounted and excused by a board of directors. A sanction imposed by an exchange, however, cannot be so readily disregarded. The board would be less likely to raise conipensation to offset any such sanction and are more likely to terminate the offending manager. ${ }^{392}$ Only by both reducing sanctions and shifting to an enforcer that values deterrence can we reduce the burden on shareliolders of dealing with the costs of securities fraud.

\section{Auctioning Class Actions}

Jonathan Macey and Geoffrey Miller offer an mnovative approach to reducing the agency costs of securities class actions. ${ }^{393}$ They propose auctioming off the claims of classes of defrauded investors to the highest bidder, wlio could then pursue those claims against the company and its officers. By consolidating the claims in the liands of a single owner, the collective action problenis that discourage investors from monitoring plaintiffs' attorneys would be eliminated. Defrauded sliareholders would be more likely to be

${ }^{391}$ See Alexander, supra note 88, at 1512 .

392 On the ability of exchanges to impose sanctions directly on corporate officers, see supra notes $254-58$ and accompanying text.

${ }^{393}$ See Macey \& Miller, supra note 41. 
compensated adequately because competition would drive the auction price to the full value of the claims.

Macey and Miller's proposal offers considerable promise for more efficiently compensating investors who have been defrauded in offerings made by the company. ${ }^{394}$ In fraud on the market cases, however, enhancing compensation should not be the goal because compensation serves no useful purpose. ${ }^{395}$ Deterrence is the appropriate focus and Macey and Miller's proposal does little to enhance deterrence. The auction proposal would discourage the tendency of plaintiffs' attorneys to settle good cases too cheaply. But companies would still be subjected to weak suits, as long as those suits provided settlement value, and corporate officers would still be able to shift liability from themselves to the corporation. For these reasons, Macey and Miller's proposal should be limited to cases in which compensation will reduce the costs of securities fraud.

\section{B. SEC Enforcement}

SEC momitoring plays an important role in guaranteeing the credibility of the exchange-based antifraud regime. ${ }^{306}$ Given the importance of that monitoring, why not simply delegate all enforcement to the SEC? The traditional answer is that the government does not have the resources to police the markets adequately. ${ }^{397}$ This answer, however, is easily parried: We should simply provide the SEC with sufficient resources to police the mar-

\footnotetext{
${ }^{34}$ It would also be useful in nonprivity cases in which the plaintiffs could demonstrate actual rehance on corporate misstatements in their trading. See supra notes 250-51 and accoinpanying text. Auctioning off such claims, however, would require overcoming the problem of individualized questions of fact that ordinarily inakes such claims inappropriate for class treatment.

${ }^{355}$ See supra notes 78-82 and accompanying text.

${ }^{36}$ See supra notes 229-33 and accompanying text.

${ }^{397}$ See Bateman Eichler, Hill Richards, Inc. v. Berner, 472 U.S. 299, 315 (1985) (recognizing that "the securities markets have grown dramatically in size and coinplexity, while Commission enforcement resources have declined" and that the SEC "does not have the resources to police the securities industry sufficiently") (internal quotation marks and citations omitted). The SEC has consistently emphasized that private actions are a necessary supplement to government enforcement. See Hearings on Sec. Litig. Reform, supra note 3, at 247 (statement of Arthur Levitt, Chairman of the Securities and Exchange Commission) (" $[\mathrm{P}]$ rivate actions are critical to ensure that issuers and those who work with them bear appropriate responsibility for their actions.").
} 
kets without private assistance. One problem with this response is that it ignores the political reality that we are unlikely to see a substantially larger SEC in an era of government downsizing. ${ }^{398}$ On a more fundamental level, increased SEC enforcement is likely to be inefficient. The SEC's status as an imdependent agency does not mean that its enforcement priorities are immune to pohtics. For example, it is hard to believe that the SEC's decision to allocate substantial agency resources to fighting imsider trading does not reflect a keen political understanding of tlie revulsion (or envy) that average Americans have for insider trading. Politicians happily provide the SEC whatever tools it deems necessary to fight insider trading and the SEC cultivates political support through its insider trading enforcement regime. ${ }^{399}$ But this strict enforcement comes at a cost, as even trivial insider trading cases are prosecuted. Such prosecutions may chill market investigation and impose substantial opportumity costs while other frauds go unprosecuted. ${ }^{400}$ The competitive pressures felt by the exchanges are unknown to the SEC, wliere career advancement turns on the number of defendants brought to the settlement table rather than on maximizing members' profits. ${ }^{401}$ Thus, as occurs in the imsider trading context, there is a risk that an SEC unconstrained by resource limitations would pursue fraud enforcement priorities consistent with maximizing its own political support, rather than maximizing tle liquidity of tlie markets at least cost. This threat, while not eliminated, is substantially reduced by limiting the SEC to a secondary fraud enforcement role.

${ }^{398}$ See Jill E. Fisch, Class Action Reform: Lessons from Securities Litigation, 39 Ariz. L. Rev. 533, 555 (1997) ("Concerns about limiting the size of government and political pressure to reduce expenditures on public enforcement support increased reliance on private enforcement.").

${ }^{399}$ See David D. Haddock \& Jonathan R. Macey, Regulation on Demand: A Private Interest Model with an Application to Insider Trading Regulation, 30 J.L. \& Econ. 311, 315-24 (1987) (arguing that the SEC's fight against insider trading is based on a desire to cater to important interest groups).

${ }^{400}$ See, e.g., SEC v. Texscan Corp., Fed. Sec. L. Rep. (CCH) I 73,702 (D. Ariz. June 30, 1989).

401 See Miller, supra note 66, at 164-65 ("[E]xchanges must balance the costs of increased surveillance against the imcreased patronage that the added confidence on the part of the public might bring in.... [P] ublic regulators, quite apart from how their activities are financed, do not have the right incentives for making busimess tradeoffs."). 


\section{CONCLUSION}

Fraud on the inarket class actions are justified as serving the goal of compensation. But deterrence, not compensation, should be the goal of any antifraud regime for secondary trading markets. Coinpensation does little to reduce the social costs of fraud on the market. The risks created by fraud on the market are largely diversifiable, so compensation serves no insurance function. And compensation does little to mitigate fraud on the market's liquidity costs. Providing compensation, however, requires a ineasure of damages in fraud on the market class actions that greatly exceeds the optimal sanction for the himited social costs created by the misstatements. That excessive sanction lies at the heart of the problems with the fraud on the market class action.

The problem of excessive sanctions is exacerbated by the practice of placing enforcement discretion in the liands of revenuemaximizing plaintiffs' attorneys. Plaintiffs' attorneys' willimgness to sacrifice deterrence for revenue is reflected in customary settlement practices through which liability is shifted froin the wrongdoing manager to the corporation. Deterrence is also undermined by the possibility of suits - cost-justified for the plaimtiffs' attorneyof little or no merit. Such litigation dilutes the deterrent effect of the securities class action yet mcreases the costs of the enforcement regime. Congress's decision to reform the fraud on the market class action in 1995 may have been necessary to restrain the abuses of that device, but the Reform Act threatens to undermine the deterrent effect of the class action because it restricts meritorious and nonmeritorious suits alike.

Placing enforcement authority in the hands of the exchanges promises to mitigate the problems of the fraud on the market class action. Exchanges' interest in maximizing trading will encourage them to focus on achieving deterrence at the lowest possible price. Institutional investors - the most active traders-will be a strong voice demanding effective enforcement. Competition among the exchanges will force them to pay heed to that voice. Should competition prove insufficient, SEC oversight could bolster exchanges' enforcement incentives.

Exchange enforcement allows for experimentation. Reducing the damages measure in fraud on the market cases should greatly decrease the cost of enforcement while increasing its accuracy. 
Only by putting enforcement in the hands of a monitor interested in maximizing deterrence, however, is it possible to reduce damages without unduly impairing incentives for vigorous enforcement. That same interest in deterrence will induce exchanges to prevent the shifting of liability from wrongdoing managers to the corporation, allowing smaller sanctions to achieve greater deterrence. Finally, exchanges can be trusted with enforcement tools-such as vicarious and secondary liability-that both enhance deterrence and reduce the overall cost of an antifraud regime.

Exchanges are not the solution to every problem of corporate governance. As the history of the NYSE shows, they exist to maximize the profits of their meinbers. Exchanges will protect the integrity of the market when doing so profits their membership. Even then, groups within the inembership may obstruct effective investor protection. Such obstruction, however, seems unlikely in the case of fraud on the market. Trading volume is the lifeblood of the exchanges and fraud on the inarket directly threatens trading volume. An exchange-based antifraud regine liarnesses the markets themselves as effective, low-cost monitors for fraud. 